\title{
Papilionoideae (Leguminosae) do Planalto Residual do Urucum, oeste do Pantanal do Mato Grosso do Sul, Brasil
}

\author{
Rosilene Rodrigues Silva ${ }^{1,3}$ e Ana Maria Goulart de Azevedo Tozzi ${ }^{2}$
}

Recebido: 9.12.2009; aceito: 2.03 .2012

\begin{abstract}
Papilionoideae (Leguminosae) of Planalto Residual do Urucum, western Pantanal region, Mato Grosso do Sul State, Brazil). The Pantanal of southern Mato Grosso do Sul is characterized by sedimentary deposits plains and isolated hills groups. One of these hills groups is the Planalto Residual do Urucum $(1065 \mathrm{~m})$, which is constituted by seven mountain ranges. Sixty-seven species of Papilionoideae, grouped into 31 genera and 11 tribes were found: Phaseoleae (Calopogonium, Camptosema, Canavalia, Centrosema, Clitoria, Eriosema, Erythrina, Galactia, Macroptilium, Phaseolus, Rhynchosia and Vigna), Dalbergieae (Aeschynomene, Andira, Chaetocalyx, Machaerium, Platypodium, Stylosanthes and Zornia), Desmodieae (Alysicarpus and Desmodium), Sophoreae (Acosmium and Sweetia), Swartzieae (Amburana and Ateleia), Crotalarieae (Crotalaria), Dipterygeae (Dipteryx), Indigoferae (Indigofera), Millettieae (Lonchocarpus), Robineae (Coursetia) and Sesbanieae (Sesbania). The most numerous genera are Desmodium and Stylosanthes (six species), Galactia and Zornia (five species). Keys, descriptions, illustrations for eight taxa and geographical distribution are provided.
\end{abstract}

Key words: flora, inventory, mountains, taxonomy

RESUMO - (Papilionoideae (Leguminosae) do Planalto Residual do Urucum, oeste do Pantanal do Mato Grosso do Sul, Brasil). O Pantanal do Mato Grosso do Sul é caracterizado por apresentar planícies de depósitos sedimentares e grupos de morros isolados. Um destes grupos de morros isolados é o Planalto Residual do Urucum (1.065 m), que é constituído de sete serras. Foram catalogadas 67 espécies de Papilionoideae, agrupadas em 31 gêneros e 11 tribos: Phaseoleae (Calopogonium, Camptosema, Canavalia, Centrosema, Clitoria, Eriosema, Erythrina, Galactia, Macroptilium, Phaseolus, Rhynchosia e Vigna), Dalbergieae (Aeschynomene, Andira, Chaetocalyx, Machaerium, Platypodium, Stylosanthes e Zornia), Desmodieae (Alysicarpus e Desmodium), Sophoreae (Acosmium e Sweetia), Swartzieae (Amburana e Ateleia), Crotalarieae (Crotalaria), Dipterygeae (Dipteryx), Indigoferae (Indigofera), Millettieae (Lonchocarpus), Robineae (Coursetia) e Sesbanieae (Sesbania). Os gêneros mais expressivos em número de espécies são Desmodium e Stylosanthes (com seis espécies), Galactia e Zornia com cinco espécies cada um. São apresentadas chaves, descrições, ilustrações para oito táxons e dados de distribuição geográfica. Palavras-chave: flora, inventário, serras, taxonomia

\section{Introdução}

O Planalto Residual do Urucum (PRU) está constituído pelas serras Jacadigo, Urucum, Tromba dos Macacos, São Domingos, Santa Cruz, Grande e Rabichão, sendo responsável pelo relevo mais alto do Pantanal sul-mato-grossense. Essas serras apresentam cotas entre 500 e $1.065 \mathrm{~m}$ de altitude.

Parte do PRU constitui uma importante província mineralógica, possuindo grandes reservas de minério de ferro e manganês. As serras desse planalto estão sob forte pressão antrópica, devido ao desmatamento para a agricultura e atividades de extração de minério. De acordo com Pott et al. (2000) cerca de 30\% da vegetação nativa tem sido substituída por policultura ou pastagem.

Em estudo do Maciço do Urucum e adjacências, Leguminosae figurou entre as famílias mais representativas em número de espécies (99), com destaque para Mimosoideae e Papilionoideae

1. Parte da tese de Doutorado da primeira Autora, Programa dse Pós-Graduação em Biologia Vegetal, Instituto de Biologia Vegetal, Departamento de Biologia Vegetal, Universidade Estadual de Campinas

2. Universidade Estadual de Campinas, Instituto de Biologia, Departamento de Biologia Vegetal, Caixa Postal 6109, 13083-970 Campinas, SP, Brasil

3. Autor para correspondência: rosilene.silva@vale.com 
(Pott et al. 2000). O inventário realizado por Silva et al. (2007) registrou 11 novas ocorrências para o Maciço do Urucum, uma de Caesalpinioideae, cinco de Mimosoideae e cinco de Papilionoideae. Além destes, alguns trabalhos com Papilionoideae foram realizados em áreas de serras brasileiras (Silva 2005, Silva 2006, Filardi et al. 2007, Silva 2010).

Papilionoideae, com aproximadamente 13.800 espécies distribuídas em 28 tribos, reúne mais de 70\% dos representantes de Leguminosae (Lewis et al.2005). Está representada por ervas, subarbsutos, arbustos, árvores ou lianas com folhas pinadas, na maioria trifolioladas ou pluriofolioladas, nunca bipinadas; a inflorescência é geralmente racemosa ou paniculada; a corola comumente papilionácea, de simetria zigomorfa e prefloração imbricada vexilar; o androceu apresenta estames livres, monadelfos, pseudomonadelfos, diadelfos ou poliadelfos; o fruto é do tipo legume e seus derivados como legume bacóide, nucóide e samaróide, criptossâmara, sâmara, lomento e drupa; as sementes possuem a região do hilo bem delimitada e a radícula com eixo infletido (Barroso et al. 1999, Gunn 1981, Polhill 1981).

Entre os trabalhos de cunho taxonômico com Papilionoideae no estado do Mato Grosso do Sul, destacam-se os de Lima et al. (2006), Polido \& Sartori (2007), Costa et al. (2008), Alves (2008) e Cristaldo (2008).

A região do PRU apresenta variações altitudinais e a importância de se estudar Papilionoideae nestes gradientes com diferentes faixas de altitude é o conhecimento científico das espécies, o que certamente auxilia em ações para o manejo, conservação e recuperação de áreas degradadas, particularmente nesta região que está sob forte pressão antrópica.

Neste trabalho é apresentado o estudo florísticotaxonômico de Papilionoideae do Planalto Residual do Urucum, incluindo chaves de identificação para os gêneros e espécies, descrições, ilustrações para os táxons e comentários sobre distribuição geográfica.

\section{Material e métodos}

O Planalto Residual do Urucum (PRU), também conhecido como Maciço do Urucum, está localizado ao sul das áreas urbanas dos municípios de Corumbá e Ladário $\left(19^{\circ} 51^{\prime}-19^{\circ} 00^{\prime} \mathrm{S}\right.$ e $\left.57^{\circ} 14^{\prime}-57^{\circ} 00^{\prime} \mathrm{W}\right)$, situados na região centro-oeste do estado do Mato Grosso do Sul, em uma área de 5.327 ha, com cotas altitudinais de 500 a $1.065 \mathrm{~m}$, sendo esta última onde se localiza o ponto mais alto do estado. A região se constitui como relevo residual originado de movimentações tectônicas terciárias (Okida \& Anjos 2000), sendo considerado o mais proeminente dos relevos residuais da borda oeste do Pantanal (Iesquierdo 1997). O conjunto de numerosas elevações que constituem o Planalto Residual do Urucum é recortado por uma série de falhas que se separam, cujas escarpas formam diversas serras, localmente denominadas morrarias (Brasil 1982). As serras que constituem esse planalto são a do Jacadigo (850 m), Santa Cruz (1.065 m), do Urucum (971 m), São Domingos (800 m), Tromba dos Macacos (951 m), Grande (500 m) e Rabichão (500-700 m), localizadas no município de Corumbá, exceto parte da serra Santa Cruz e a serra do Rabichão, situadas em Ladário. O clima é do tipo tropical megatérmico, classificado como Awa no sitema de Köeppen (Soriano 2000). O solo predominante é o minério de ferro. A vegetação é constituída por florestas estacionais deciduais e semideciduais, cerrado stricto sensu, cerradão, campo cerrado, campo limpo e campo sujo de cerrado, vegetação de bancada laterítica, matas ciliares e de galeria (Pott et al. 2000).

$\mathrm{Na}$ amostragem florística realizada em todas as serras do PRU, a lista de espécies de Papilionoideae foi obtida a partir da realização de excursões com duração de cinco dias em cada serra, no período de dezembro de 2002, agosto de 2003 a dezembro de 2004. Uma coleta complementar foi feita em julho de 2005 , percorrendo uma área de cerca de 3.000 ha, através de coletas assistemáticas, abrangendo as diferentes formações vegetacionais encontradas no PRU. Os exemplares coletados foram processados de acordo com as técnicas usuais de herborização e identificados com auxílio de bibliografia especializada, com base no exame de material-tipo, sempre que possível, através de imagens disponíveis na Internet, em consultas a alguns especialistas e na análise de exsicatas de herbários nacionais e um estrangeiro (USZ).

A terminologia usada na caracterização dos tipos de hábito foi baseada em Guedes-Bruni et al. (2002), para o tipo de indumento em Hickey \& King (2004), para o tipo de inflorescência, em Webberling (1992), para a morfologia das pétalas, em Stirton (1981), para o tipo de fruto, em Barroso et al. (1999) e para o tipo de semente em Gunn (1981). A classificação adotada para tribos e gêneros foi a de Lewis et al. (2005).

As chaves para identificação dos táxons e as descrições correspondem à amplitude de variação dos espécimes coletados nas serras do planalto, 
sendo os táxons apresentados em ordem alfabética. As ilustrações foram feitas para as espécies pouco conhecidas ou mais expressivas nas fitofisionomias estudadas. Dados sobre a distribuição geográfica dos táxons no país foram obtidos a partir de revisões dos gêneros estudados e/ou estudos com Papilionoideae.

\section{Resultados e Discussão}

No inventário florístico de Papilionoideae (Leguminosae) no Planalto Residual do Urucum foram reconhecidas 67 espécies, agrupadas em 31 gêneros e 11 tribos. O número de espécies foi superior ao encontrado no estudo de composição florística para a região do Maciço do Urucum e adjacências (Pott et al. 2000), que registrou 38 espécies. Portanto, neste estudo foram acrescidos 29 táxons de Papilionoideae em relação ao estudo realizado por Pott et al. (2000). As tribos mais representativas foram Phaseoleae com 12 gêneros: Calopogonium (1 espécie), Camptosema (1), Canavalia (1), Centrosema (3), Clitoria (2), Eriosema (2), Erythrina (1), Galactia (5), Macroptilium (3), Phaseolus (1), Rhynchosia (3) e Vigna (3). Dalbergieae com sete gêneros: Aeschynomene (4), Andira (1), Chaetocalyx (1), Machaerium (1), Platypodium (1), Stylosanthes (6) e Zornia (5); Desmodieae com dois gêneros: Alysicarpus (1) e Desmodium (6); e Sophoreae, com dois gêneros: Acosmium (1) e Sweetia (1); Swartzieae com dois gêneros: Amburana (1) e Ateleia (1). As demais tribos contam apenas com um gênero: Crotalarieae (Crotalaria), Dipterygeae (Dipteryx), Indigoferae (Indigofera), Millettieae (Lonchocarpus), Robineae (Coursetia) e Sesbanieae (Sesbania). Os gêneros mais expressivos em número de espécies foram Desmodium e Stylosanthes, com seis espécies cada e Galactia e Zornia com cinco espécies cada um.

Quanto ao seu hábito, os subarbustos foram representados por 27 espécies (40,3\%), as ervas por oito espécies $(11,9 \%)$, as árvores por 11 espécies $(16,4 \%)$, os arbustos por nove espécies $(13,4 \%)$ e as trepadeiras por 12 espécies $(17,9 \%)$. As tribos com maior número de representantes subarbustivos foram Phaseoleae e Dalbergieae, ambas com nove representantes. Também Phaseoleae foi a tribo mais expressiva entre as trepadeiras, segunda maior em porcentagem, estando representada por 10 espécies. Segundo Lewis et al. (2005), Phaseoleae é a maior tribo em número de gêneros (89), e a segunda maior em número de espécies (1.554-1.580), sendo a primeira, Galegae sens. lat. com 2.880-3.180 espécies.

Na serra Santa Cruz houve a maior ocorrência de gêneros e espécies $(24 ; 51)$, seguida pelas serras São Domingos $(19 ; 25)$, Tromba dos Macacos $(19 ; 23)$, Jacadigo (17; 24); Urucum $(15 ; 22)$, Grande $(15 ; 17)$, e Rabichão (14; 23).

Em relação ao gradiente altitudinal, as espécies de Papilionoideae se distribuem em diferentes altitudes, assim como nas distintas formações vegetacionais. Pode-se dizer que uma parcela significativa das espécies ocorre dentro de uma faixa altitudinal entre 100 e $900 \mathrm{~m}$. Na fitofisionomia de floresta estacional decidual foi registrado o maior número de táxons (40), e entre, os exclusivos desta formação estão, Acosmium cardenasii, Aeschynomene viscidula, Alysicarpus vaginalis, Centrosema brasiliensis, Coursetia hassleri, Erythrina dominguezii, G. latisiliqua var. latisiliqua, Indigogera guaranitica, Lonchocarpus pluvialis, L. variabilis, Rhynchosia edulis, $R$. minima, Sesbania virgata, Stylosanthes capitata, Sweetia fruticosa e Vigna caracalla. A expressiva riqueza de táxons nestas formações deciduais provavelmente está relacionada ao fato destas estarem assentadas sobre solos ricos, com boa saturação por bases e de pH moderado a alto (Ratter et al. 1978).

Dezesseis espécies apresentaram ocorrência em mais de dois tipos de vegetação, entre elas, Aeschynomene americana, Amburana cearensis, Andira inermis, Ateleia guaraya, Calopogonium mattogrossensis, Camptosema ellipticum, Centrosema sagittatum, Crotalaria micans, Desmodium incanum, Dipteryx alata, Indigofera suffruticosa, Machaerium aculeatum, M. hirtum, M. villosum, Platypodium elegans e Stylosanthes guianensis.

Chave para os gêneros de Papilionoideae ocorrentes no Planalto Residual do Urucum

1. Corola papilionácea formada por 5 pétalas diferenciadas em estandarte, alas e pétalas da quilha

2. Folíolos com estipelas caducas a persistentes

3. Folhas 3-60-folioladas

4. Ervas a subarbustos

2. Aeschynomene

4. Árvores

5. Venação dos folíolos broquidódroma; fruto drupa .... 5. Andira

5. Venação dos folíolos eucamptódroma; fruto sâmara 25. Platypodium 
3. Folhas 1-11-folioladas

6. Árvores armadas; flores com alas reduzidas, às vezes quase inconspícuas, pétalas da quilha alongadas

18. Erythrina

6. Trepadeiras, ervas, subarbustos a arbustos inermes; flores com alas um pouco menores ou do mesmo tamanho das pétalas da quilha

7. Estilete barbado

8. Cálice infundibuliforme; alas não sobressaindo das demais pétalas; pétalas da quilha falcadas e lateralmente não torcidas 12. Clitoria

8. Cálice campanulado ou tubuloso; alas mais conspícuas que as demais pétalas; pétalas da quilha sigmóides e lateralmente torcidas

22. Macroptilium

7. Estilete glabro

9. Flores ressupinadas; estandarte geralmente calcarado no dorso; estigma barbado

10. Centrosema

9. Flores não ressupinadas; estandarte nunca calcarado no dorso; estigma glabro

10. Inflorescência em pseudoracemo

11. Corola azul a lilás; estandarte suborbicular

9. Canavalia

11. Corola vermelha; estandarte curvo

8. Camptosema

10. Inflorescência em racemo, fascículo de racemos ou panícula

12. Estandarte externamente com tricomas bifurcados adpressos; conectivo apiculado

20. Indigofera

12. Estandarte com tricomas simples; conectivo não apiculado

13. Fruto lomento

15. Desmodium

13. Fruto legume

14. Valvas do legume lineares ou lunadas

24. Phaseolus

14. Valvas do legume retas, falcadas ou ascendentes

15. Cálice 5-laciniado, bilabiado; lábio superior bidentado, semisoldado, lábio inferior tridenteado

7. Calopogonium

15. Cálice 4-laciniado, não labiado; lacínias partidas, desiguais, maiores que o tubo

19. Galactia

2. Folíolos sem estipelas

16. Anteras dimorfas

17. Estandarte basalmente com apêndices restritos à lâmina ou estendidos até a unguícula; fruto legume inflado

14. Crotalaria

17. Estandarte sem apêndices; fruto lomento

18. Estípulas amplexicaules, bidentadas

28. Stylosanthes

18. Estípulas peltadas, com aurícula estendida abaixo do ponto de inserção

31. Zornia

16. Anteras uniformes

19. Pétalas da quilha clocleadas, espiraladas, lateral a longitudinalmente torcidas

30. Vigna

19. Pétalas da quilha não clocleadas, não espiraladas e sem torção

20. Fruto lomento

21. Folhas simples; cálice pubérulo-uncinado

3. Alysicarpus

21. Folhas nunca simples; cálice setoso-glandular

11. Chaetocalyx

20. Fruto legume, drupa ou sâmara

22. Cálice turbinado-campanulado, punctado

16. Dipteryx

22. Cálice campanulado a cilíndrico, não-punctado

23. Folhas 1-3-folioladas

24. Ovário estipitado; funículo central

26. Rhynchosia

24. Ovário séssil; funículo na extremidade do hilo 17. Eriosema

23. Folhas com mais de 3 folíolos

25. Folíolos 5-9 pares

26. Estandarte com calosidades na base da lâmina; ovário granulífero

13. Coursetia 
26. Estandarte sem calosidades na base da lâmina; ovário sem grânulos

21. Lonchocarpus

25. Folíolos 10-57 pares

27. Inflorescência em panícula; fruto sâmara

22. Machaerium

27. Inflorescência em racemo; fruto legume 27. Sesbania

1. Corola não papilionácea formada por cinco pétalas sem diferenciação, subiguais ou corola reduzida

a uma só pétala vexilar

28. Pétalas 5; estames 10 , livres entre si

29. Corola alva; pétalas subiguais 29. Sweetia

29. Corola amarela; pétalas iguais entre si 1. Acosmium

28. Pétala 1; estames 10, concrescidos na base

30. Estigma punctiforme; fruto criptossâmara

30. Estigma peltado; fruto samaróide .

4. Amburana 6. Ateleia

1. Acosmium Schott, Syst. Veg. 4(2): 406. 1827.

\subsection{Acosmium cardenasii H.S. Irwin \& Arroyo,} Brittonia 26: 264. 1974.

Figura 1

Árvores, 3,5-13 m alt. Ramos cilíndricos, quando jovens denso-estrigulosos e quando adultos glabros. Folhas imparipinadas a paripinadas, 17-39-folioladas; pecíolo $0,5-1,5 \mathrm{~cm}$ compr.; estípulas não vistas, caducas; folíolos 0,7-4,5 × 0,3-1,8 cm, alternos a opostos, concolores, oblongos, elípticos a obovais, base obtusa, ápice mucronado, ambas as faces estrigosas a glabras. Inflorescências racemosas; pedúnculo 3-8 cm compr.; brácteas e bractéolas não vistas, caducas; cálice 2,5-4 mm compr., verde, lacínias estrigulosas, pubescentes; corola amarela, pétalas 4-7 mm compr., elípticas a obovais, esparsamente pubescentes a glabras em ambas as faces; estames livres; ovário estipitado, tomentoso, estilete levemente curvo, estigma punctiforme. Legumes samaróides, 2,5-4,7 cm compr., castanhos a marrons, estipitados; sementes oblongas, de testa ferrugínea.

Material examinado: BRASIL. Mato Grosso Do Sul: Corumbá, Piraputangas, encosta do Maciço do Urucum, 30-V-1951, fr., Bastos s.n. (RB/73766); Serra do Jacadigo, 25-X-2003, fl., Silva \& Velásquez 437 (UEC); 30-VII-2004, fr., Silva \& Velásquez 1051 (UEC); 20-X-2004, fl., Silva \& Velásquez 1186 (UEC); 23-XI-2004, fr., Silva \& Velásquez 1296 (UEC); Serra Urucum, acesso Urucum Mineração, 28-I-2003, fr., Silva \& Calisto 202 (UEC); 6-X-2003, fl., Silva \& Calisto 304 (UEC); 17-XII-2004, fr., Silva \& Calisto 1353 (UEC); Serra São Domingos, 25-X-2004, fl., Silva \& Velásquez 1224 (UEC); 27-XII-2004, fr., Silva \& Velásquez 1371 (UEC); Serra Tromba dos Macacos, fazenda Tarumã, 17-VI-1996, fr., Pott 7820 (CPAP, HMS); Serra Tromba dos Macacos, 27-I-2003, fr., Silva \& Velásquez 181 (UEC); 23-X-2003, fl.,
Silva \& Velásquez 409 (UEC); 29-VII-2004, fr., Silva \& Velásquez 1038 (UEC); 16-X-2004, fl., Silva \& Velásquez 1246 (UEC); 25-XI-2004, fr., Silva \& Velásquez 1313 (UEC); Serra Santa Cruz, 29-X-2003, fl., Silva \& Velásquez 500 (UEC); 17-XII-2004, fr., Silva \& Velásquez 673 (UEC); Serra Grande, 17-I-2003, Silva \& Velásquez 137 (UEC); 24-XI-2003, fr., Silva \& Velásquez 605 (UEC); 18-XII-2003, fr., Silva \& Velásquez 686 (UEC); 24-XI-2004, fr., Silva \& Velásquez 1304 (UEC). Ladário, Serra do Rabichão, fazenda Uruba, 16-IV-1994, fr., Pott et al. 2253 (CPAP, MBM); 8-VI-1994, fr., Hatschbach et al. 60780 (MBM, SPF); 10-XII-2003, fr., Silva \& Silva 626 (UEC); 21-X-2003, fl., Silva \& Silva 387 (UEC); 10-XII-2003, fr., Silva \& Silva 626A (UEC); 10-II-2004, fr., Silva \& Silva 619 (UEC); 16-III-2004, fr., Silva \& Silva 766 (UEC); 18-V-2004, fr., Silva \& Silva 954 (UEC); 18-XI-2004, fr., Silva \& Silva 1282 (UEC).

No Brasil, ocorre no estado de MS (Rodrigues \& Tozzi 2009). No PRU, a espécie foi encontrada em fitofisionomia de floresta estacional decidual, em altitudes de 103 a $481 \mathrm{~m}$.

2. Aeschynomene L., Sp. P1. 2: 713. 1753.

Chave para as espécies de Aeschynomene

1. Folhas paripinadas; estípulas peltadas 2.1. A. americana

1. Folhas imparipinadas; estípulas não peltadas

2. Folhas 5-9-folioladas; ramos glanduloso-oleíferos, híspidos ... 2.4. A. viscidula

2. Folhas 3-5-folioladas; ramos sem glândulas, pubescentes

3. Erva xilopodífera; inflorescência laxa 2.2. A. gracilis

3. Subarbusto; inflorescência congesta 2.3. A. histrix 


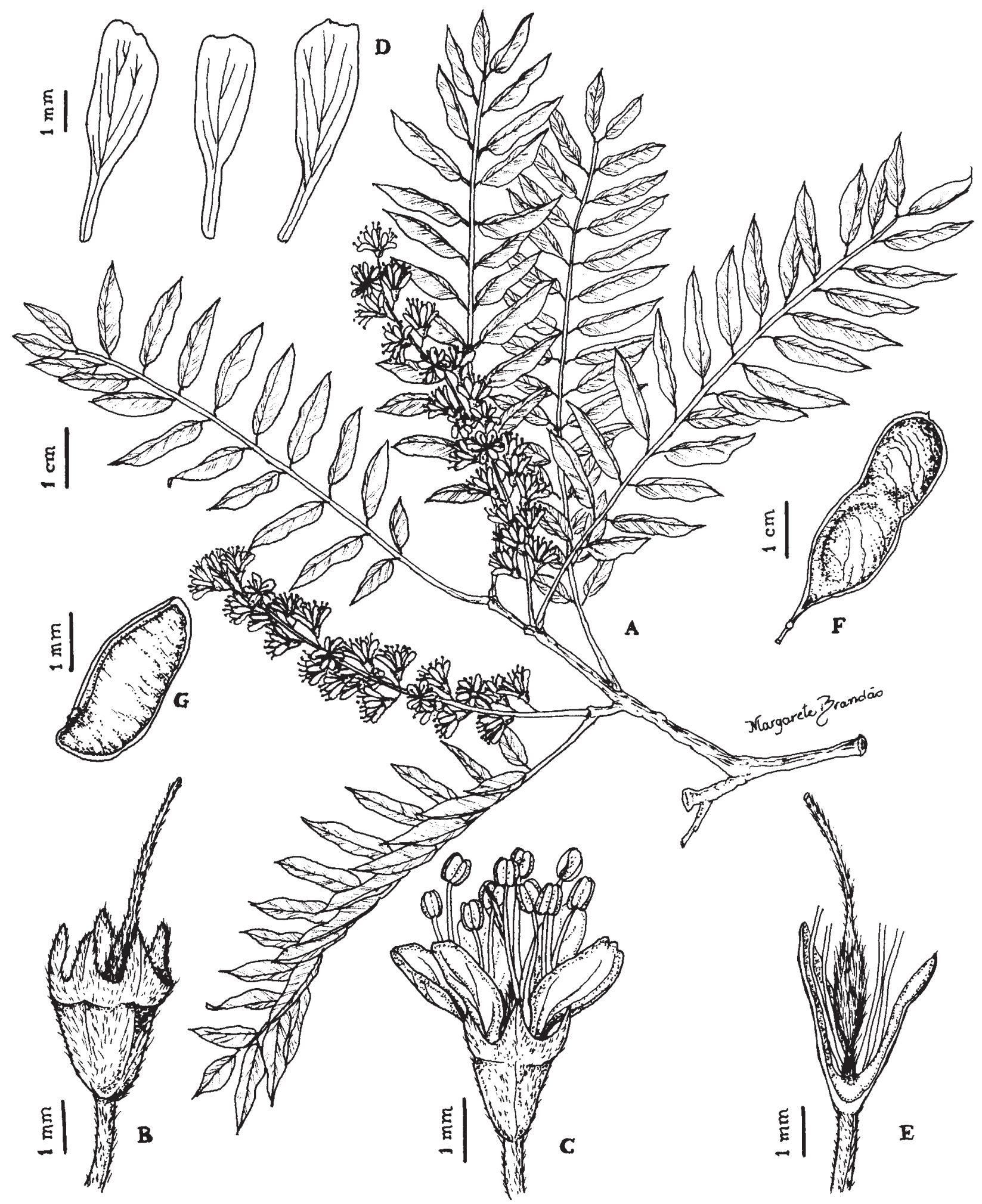

Figura 1. Acosmium cardenasii. A. Ramo com inflorescência. B. Cálice. C. Flor. D. Detalhe da face interna das pétalas. E. Vista interna do cálice evidenciando o gineceu. F. Fruto. G. Semente (A-E: R.R. Silva \& R. Silva 1186; F-G: R.R. Silva \& M.V. Silva 1282, UEC).

Figure 1. Acosmium cardenasii. A. Branch with inflorescence. B. Calyx. C. Flower. D. Petals internal face detail. E. Internal view of the calyx showing the gynoecium. F. Fruit. G. Seed (A-E: R.R. Silva \& R. Silva 1186; F-G: R.R. Silva \& M.V. Silva 1282, UEC). 
2.1. Aeschynomene americana L., Sp. Pl. 2: 713. 1753.

Subarbustos, 0,4-1,3 m alt. Ramos eretos a decumbentes, sem glândulas, hirsuto-capitados, amarelados, às vezes com nódulos intumescidos avermelhados. Folhas paripinadas, 20-60 folioladas; pecíolo 0,5-0,9 mm compr.; estípulas 8-16 mm compr., peltadas, subulado-acuminadas, apêndice basal erosotruncado; folíolos 5-12 × 1-2 mm, falcado-lineares, base oblíqua, ápice agudo, ambas as faces glabras. Inflorescências axilares, 2-5-floras; pedúnculo 3-10 mm compr.; brácteas cordadas, base truncada, ápice acuminado; bractéolas cordadas a lanceoladas; cálice 4-5 mm compr., verde, bilabiado, campanulado, híspido, o segmento superior emarginado, o inferior trífido; corola rósea; estandarte 3-5,5 mm compr., róseo com guias vináceos, suborbicular a obcordado; alas 4-6 mm compr., obovais, esculturadas, auriculadas; pétalas da quilha 5-7 $\mathrm{mm}$ compr., falcadas, auriculadas; estames 10, diadelfos; ovário estipitado, pubescente; estilete encurvado; estigma terminal. Lomentos 1,8-3,5 cm compr., castanhos, estipitados, 2-6 articulados, margem superior reta, inferior crenada, artículos 5-6 mm compr., orbiculares, pubescentes a glabrescentes; sementes reniformes, testa castanho-escura.

Material examinado: BRASIL. MAto Grosso do SuL: Serra São Domingos, Planalto Residual do Urucum, 22-III-2004, fr., Silva \& Velásquez 802 (UEC); Serra Santa Cruz, 29-X-2003, fr., Silva \& Velásquez 505 (UEC); 19-XII-2004, fr., Silva \& Velásquez 730 (UEC).

No Brasil, ocorre nos estados de RR, PA, AM, AC, RO, MA, CE, BA, MT, GO, DF, MS, MG, ES, SP, RJ e SC (Lima \& Oliveira 2010a). No PRU, a espécie foi encontrada em florestas estacionais deciduais e semideciduais e em campo cerrado, entre 180 e 693 m de altitude.

2.2. Aeschynomene gracilis Vogel, Linnaea 12: 891. 1838.

Ervas xilopodíferas, 5-20 cm alt. Ramos prostrados, sem glândulas, pubescentes. Folhas imparipinadas, 3-5-folioladas; pecíolo 2-3 mm compr.; estípulas 2-4 mm compr., lanceoladas, não peltadas, margem ciliada; folíolos 3-8 × 2-4 mm, obovais, base oblíqua, arredondada a subcordada, ápice arredondado, apiculado, face adaxial pubescente a glabrescente, face abaxial pubescente. Inflorescências em racemos, axilares, laxas, 2-floras, pubescentes; pedúnculo 0,5-2 cm compr.; brácteas e bractéolas ovais, estriadas, pubescentes; cálice 2-2,5 mm compr., verde, campanulado, dentado, pubescente; corola amarela; estandarte 4-6 mm compr., orbicular, externamente pubescente, base unguiculada; alas 3-4 mm compr., oblongas, esculturadas, auriculadas, base unguiculada, ápice acuminado; pétalas da quilha 4-5 mm compr., falcadas, curtamente auriculadas, base unguiculada; estames 10, diadelfos; ovário estipitado, pubescente a glabrescente; estilete encurvado; estigma terminal. Lomentos 6-9 mm compr., marrons a castanhos, falcados, estipitados, 2-3-articulados; artículos $3 \mathrm{~mm}$ compr., obovais, pubescentes; sementes reniformes, testa marrom.

Material examinado: BRASIL. Mato Grosso Do Sul: Corumbá, Serra do Urucum, Planalto Residual do Urucum, 4-X-1984, fr., Conceição 1612 (CPAP); 22-I-2003, fl., fr., Silva \& Calisto 168 (UEC); 3-X-2003, fr., Silva \& Calisto 288 (UEC); 24-VII-2004, fl., fr., Silva \& Calisto 1003 (UEC); Serra Santa Cruz, Planalto Residual do Urucum, 10-I-2003, fl., fr., Silva \& Silva 114 (UEC); 7-II-2003, fl., Silva \& Ramires 243 (UEC); 23-VII-2004, fl., fr., Silva \& Ramires 996 (UEC).

No Brasil, ocorre nos estados de RR, AP, PA, AM, AC, PI, CE, PE, BA, AL, MT e GO (Lima \& Oliveira 2010a) e Mato Grosso do Sul (Silva et al. 2007). No PRU, a espécie foi coletada em campo cerrado, entre 763 e $1.023 \mathrm{~m}$ de altitude.

\subsection{Aeschynomene histrix Poir., Encycl. Suppl. 4(1):} 77. 1816.

Subarbustos, 0,2-1 m alt. Ramos eretos a suberetos, pubescentes a pubérulos, canescente, amarelo-ouro. Folhas imparipinadas, 3-5-folioladas; pecíolo 0,3-0,7 mm compr.; estípulas 3-4 mm compr., oval-lanceoladas a lanceoladas, não peltadas; folíolos 5-11 $\times$ 2-3 mm, oblongo-elípticos a obovais, base oblíqua, ápice obtuso, apiculado, face adaxial pubescente a glabrescente, face abaxial pubescente. Inflorescências racemosas, axilares, congestas, 4-15-floras; pedúnculo 0,9-2 cm compr; brácteas e bractéolas ovais; cálice 2-3 mm compr., verde, campanulado, lacínias desiguais, de ápice ciliado; corola amarela; estandarte 6-7 mm compr., amarelo com guias vináceos, suborbicular, externamente pubescente; alas 5-7 mm compr., obovais, glabras, auriculadas; pétalas da quilha 6-7 $\mathrm{mm}$ compr., falcado-oblongas, glabras; estames 10, diadelfos; 
ovário estipitado, pubescente a glabrescente; estilete encurvado; estigma terminal. Lomentos 6-7 mm compr., pretos, margem superior reta, inferior crenada, 2-3-articulados; artículos 2,5-3 mm compr., obovais, reflexos, crispo-pubescentes; sementes reniformes, testa lisa, castanho-escura com pontuações vermelhas.

Material examinado: BRASIL. MAto Grosso do SuL: Corumbá, Serra São Domingos, Planalto Residual do Urucum, 20-XI-2004, fl., fr., Silva \& Velásquez 587 (UEC); Serra Grande, Planalto Residual do Urucum, 17-I-2003, fl., Silva \& Velásquez 141 (UEC). Ladário, Serra do Rabichão, Planalto Residual do Urucum, 17-X-2003, fl., fr., Silva \& Silva 353 (UEC); 13-XI-2003, fl., fr., Silva \& Silva 550 (UEC); 10-XII-2003, fl., Silva \& Silva 353 (UEC); 26-II-2004, fl., Silva \& Silva 742 (UEC); 16-XI-2004, fl., fr., Silva \& Silva 127 (UEC).

Ocorre na América Central, estando amplamente distribuída na América do Norte e na América do Sul (Rudd 1955). No Brasil, ocorre nos estados de RR, AP, PA, AM, AC, PI, CE, PE, BA, AL, MT, GO e MS (Lima \& Oliveira 2010a). No PRU, a espécie foi coletada em floresta estacional decidual e campo cerrado, entre 115 e $740 \mathrm{~m}$ de altitude.

\subsection{Aeschynomene viscidula Michx., Fl. Bor.-Amer.}

\section{2: 74.1803 .}

Subarbustos, 1-1,2 m alt. Ramos cilíndricos, suberetos, glanduloso-oleíferos, híspido-capitados. Folhas imparipinadas, 5-9-folioladas; pecíolo 2-3 mm compr.; estípulas 2-4 mm compr., deltóides, não peltadas; folíolos 5-10 × 3-7 mm compr., obovais, base obtusa, ápice agudo-mucronulado, face adaxial reticulada, pubescente, face abaxial subvilosocapitada. Inflorescências racemosas, até 8-floras, viscidulosas; pedúnculo 1,5-6,5 cm compr.; brácteas estipuliformes, hispídulas; bractéolas ovais, hispídulas; cálice 2,5-3 mm compr., verde, campanulado, lacínias subiguais, pubescentes; corola amarela; estandarte 6-7 mm compr., orbicular, externamente pubescente; alas 5-6 mm compr., obovais, glabras; pétalas da quilha 5-6 mm compr., falcadas, glabras; estames 10, diadelfos; ovário estipitado, pubescente a glabrescente; estilete encurvado; estigma terminal. Lomentos 6-12 mm compr., marrons, sub-reflexos, patentes, 2-3-articulados; artículos 3-4 mm compr., obovais, tomentosos e setulosos; sementes reniformes, testa castanha, pintalgada de cor vinho.
Material examinado: BRASIL. Mato Grosso Do Sul: Corumbá, Serra do Jacadigo, acesso pelo sítio Nossa Sra. Aparecida, 16-XII-2003, fl., fr., Silva \& Velásquez 658 (UEC). Ladário, Serra do Rabichão, Planalto Residual do Urucum, 18-III-2004, fr., Silva \& Silva 771 (UEC).

No Brasil, ocorre nos estados de BA e CE (Fernandes 1996). Também citada para o estado do MS (Silva et al. 2007) e para os estados de PE, AL e SE (Lima \& Oliveira 2010a). No PRU, foi coletada em fitofisionomia de floresta estacional decidual, a $198 \mathrm{~m}$ de altitude.

3. Alysicarpus Desv., J. Bot. Agric. 1: 120. 1813.

\subsection{Alysicarpus vaginalis (L.) DC., Prodr. 2: 353. 1825}

Subarbustos, 40-60 cm alt. Ramos pubescenteuncinados. Folhas 0,9-7,3 × 0,9-2,8 cm, simples, alternas, lanceoladas, obovais a oblongas, base cordada, ápice obtuso, apiculado, arredondado a emarginado, face adaxial pubérulo-uncinada, face abaxial pubescente-uncinada; pecíolo 0,3-11 mm compr.; estípulas 10-11 mm compr., paleáceas, lanceoladas, base eroso-truncada, coalescentes apenas na base, nervadas; Inflorescências em pseudo-racemos, axilares, 8-18-floras; brácteas oval-acuminadas, base subtruncada, margem ciliado-uncinada; bractéolas lanceoladas, pubérulo-uncinadas, ápice ciliado; cálice 0,8-0,9 mm compr., verde, nervado, lacínias lanceoladas, pubérulo-uncinadas, margem ciliada; corola rósea; estandarte 20-22 mm compr., orbicular, glabro, base unguiculada, ápice emarginado; alas 11-12 mm compr., oblongas, base unguiculada; pétalas da quilha $10 \mathrm{~mm}$ compr., oblongas; estames 10 , monadelfos; ovário curto-estipitado, pubescente; estilete curvo; estigma terminal. Lomentos 2,3-2,1 cm compr., 5-7-articulados, marrons a cinza-escuros; artículos pubescentes, com tricomas uncinados, ápices mucronados; sementes oblongas, testa marrom pintalgada de cor vinho.

Material examinado: BRASIL. MAto Grosso do SuL: Ladário, Serra do Rabichão, Planalto Residual do Urucum, acesso pela fazenda Uruba, 26-II-2004, fl., Silva \& Silva 744 (UEC); 18-III-2004, fl., fr., Silva \& Silva 769 (UEC).

No Brasil, ocorre nos estados de TO, PI, MT, GO, MS, SP e PR (Lima 2010a). No PRU, foi coletada na floresta estacional decidual, altitudes de 169 a $210 \mathrm{~m}$. 
4. Amburana Schwacke \& Taub., Nat. Pflanzenfam. 3(3): 387.1894.

4.1. Amburana cearensis (Allemão) A.C. Sm., Trop. Woods 62: 30. 1940.

Figura 2

Árvores, 7-20 m alt. Ramos cilíndricos, avermelhados, glabrescentes. Folhas pinadas, imparipinadas, 8-11-folioladas; pecíolo 0,9-1,2 cm compr.; estípulas e estipelas ausentes; folíolos 2-3,9 × 1,5-2,1 cm, alternos, largo-elípticos, base arredondada, ápice obtuso a retuso, face adaxial glabra, face abaxial pubescente a glabrescente. Inflorescências em panículas, 5-20-floras; pedúnculo 1,5-3 cm compr.; brácteas caducas; bractéolas ovais, pubescentes; cálice 20-30 mm compr., verde-avermelhado, tubuloso, lacínias 5, tomentosas, quase obsoletas; corola creme a rosada; pétala 1, orbicular, serícea na face externa, base cordada, curtamente unguiculada, ápice emarginado; estames 10, unidos na base às lacínias do cálice; ovário estipitado, glabro, estípite aderido ao tubo de cálice, tomentoso; estilete encurvado; estigma punctiforme. Criptossâmaras 6-6,5 cm compr., marrom-escuras a pretas, endocarpo membranáceo; sementes com evaginações, oblongas, testa marrom, glabra.

Material examinado: BRASIL. Mato Grosso do Sul: Corumbá, Jacadigo, Planalto Residual do Urucum, 14-III-1992, fl., Reis s.n. (COR/3346); 30-IV-2004, fl. fr., Silva \& Velásquez 933 (UEC); 30-VII-2004, fr., Silva \& Velásquez 1050 (UEC); Serra Tromba dos Macacos, fazenda Tarumã, 17-VI-1996, fr., Pott 7822 (CPAP, HMS); Serra São Domingos, Planalto Residual do Urucum, 26-IV-2004, Silva \& Velásquez 892 (UEC); Serra Grande, Planalto Residual do Urucum, 31-III-2004, fl., Silva \& Velásquez 905 (UEC). Ladário, fazenda Uruba, 8-VI-1994, fr., Hatschbach et al. 60801 (CPAP, MBM); Serra do Rabichão, Planalto Residual do Urucum, 19-IV-2004, fl., fr., Silva \& Silva 864 (UEC).

No Brasil, ocorre nos estados de PI, CE, PB, PE, BA, AL, GO, MS, MG, ES e RJ (Lima 2010b). No PRU, foi coletada em floresta estacional decidual, cerradão e bancada laterítica, entre 115 e $553 \mathrm{~m}$ de altitude.

5. Andira Juss., Gen. P1.: 363. 1789. nom. cons.

5.1. Andira inermis (Wright) DC., Prodr. 2: 475.1825.

Árvores, 7-15 m alt. Ramos cilíndricos, glabros. Folhas alternas, imparipinadas, 9-11-folioladas; pecíolo 20-40 mm compr.; estípulas 1,5-5 mm compr., caducas; estipelas 1,5-3 mm compr., setáceas, rigídulas, persistentes; folíolos $9-15 \times 2,5-3,5 \mathrm{~cm}$, opostos, venação broquidódroma, oblongos, base arredondada a obtusa, ápice retuso, ambas as faces glabras. Inflorescências em panículas densifloras, eixos tomentosos; brácteas e bractéolas subuladas, tomentosas, caducas; cálice 3-4 mm compr., cano-ferrugíneo, campanulado, lacínias pouco distintas, dentadas, desiguais, tomentosas; corola lilás a roxa; estandarte $3 \mathrm{~mm}$ compr., com mácula central amarela, orbicular, base unguiculada, ápice emarginado, glabro; alas 2-3 mm compr., oboval-oblongas, curtamente auriculadas, base unguiculada, esculturadas; pétalas da quilha 2-3 mm compr., curvas, curtamente auriculada, base unguiculada, glabra; estames 10, diadelfos; ovário oblongo, estipitado, tomentoso a glabro na sutura, indumento amarelo-ouro; estilete curvo; estigma diminuto, terminal. Drupas 1,5-2 cm compr., castanhas, oblíquas, obovais, glabras; semente 1 , obovóide, testa castanha.

Material examinado: BRASIL. Mato Grosso do Sul: Corumbá, Serra Santa Cruz, Planalto Residual do Urucum, 17-XI-2000, fl., Ávila 6 (COR); 8-I-2003, fr., Silva \& Silva 103 (UEC); 28-XII-2004, fl., fr., Silva \& Velásquez 1374 (UEC); Serra do Urucum, Planalto Residual do Urucum, 27-X-2004, fl., Silva \& Velásquez 1254 (UEC); 17-XII-2004, fl., fr., Silva \& Calisto 1357 (UEC); Serra São Domingos, Planalto Residual do Urucum, 13-XII-2003, fl., fr., Silva \& Velásquez 124 (UEC); 23-IX-2004, fl., Silva \& Velásquez 1151 (UEC); 22-XII-2004, fl., fr., Silva \& Velásquez 1367 (UEC); Serra Tromba dos Macacos, Planalto Residual do Urucum, 20-XII-2004, fl., fr., Silva \& Velásquez 1361 (UEC).

No Brasil, ocorre nos estados de AP, AM, AC, MA, MT, GO, MS, MG, PR e SC (Pennington 2003). No PRU, ocorre em florestas estacionais deciduais e semidecidualis e cerrado, entre 219 e $775 \mathrm{~m}$ de altitude.

6. Ateleia (DC.) Benth., Leg. Gen. Comm. 91: 101.1837.

6.1. Ateleia guaraya Herzog, Repert. Spec. Nov. Regni Veg. 7: 55. 1909.

Figura 3

Árvores, 2-10 m alt. Ramos cilíndricos, glabros. Folhas imparipinadas, 6-13-folioladas, alternas; 


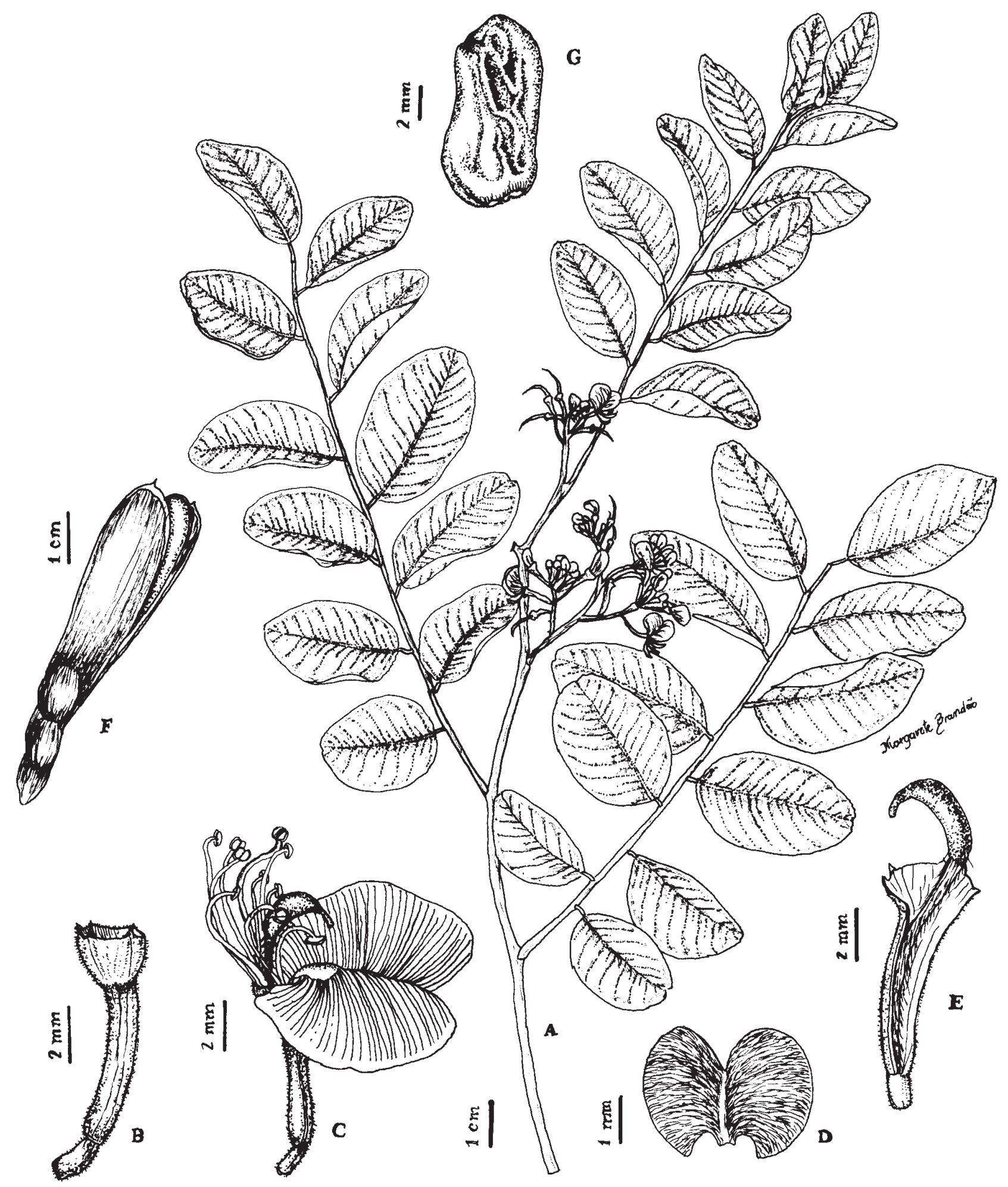

Figura 2. Amburana cearensis. A. Ramo com inflorescência. B. Detalhe do cálice. C. Flor completa. D. Vista da face externa da pétala. E. Vista interna do cálice evidenciando o gineceu. F. Fruto. G. Semente (R.R. Silva \& M.V. Silva 864, UEC).

Figure 2. Amburana cearensis. A. Branch with inflorescence. B. Calyx detail. C. Complete flower. D. Petal external face view. E. Internal view of the calyx showing the gynoecium. F. Fruit. G. Seed (R.R. Silva \& M.V. Silva 864, UEC). 

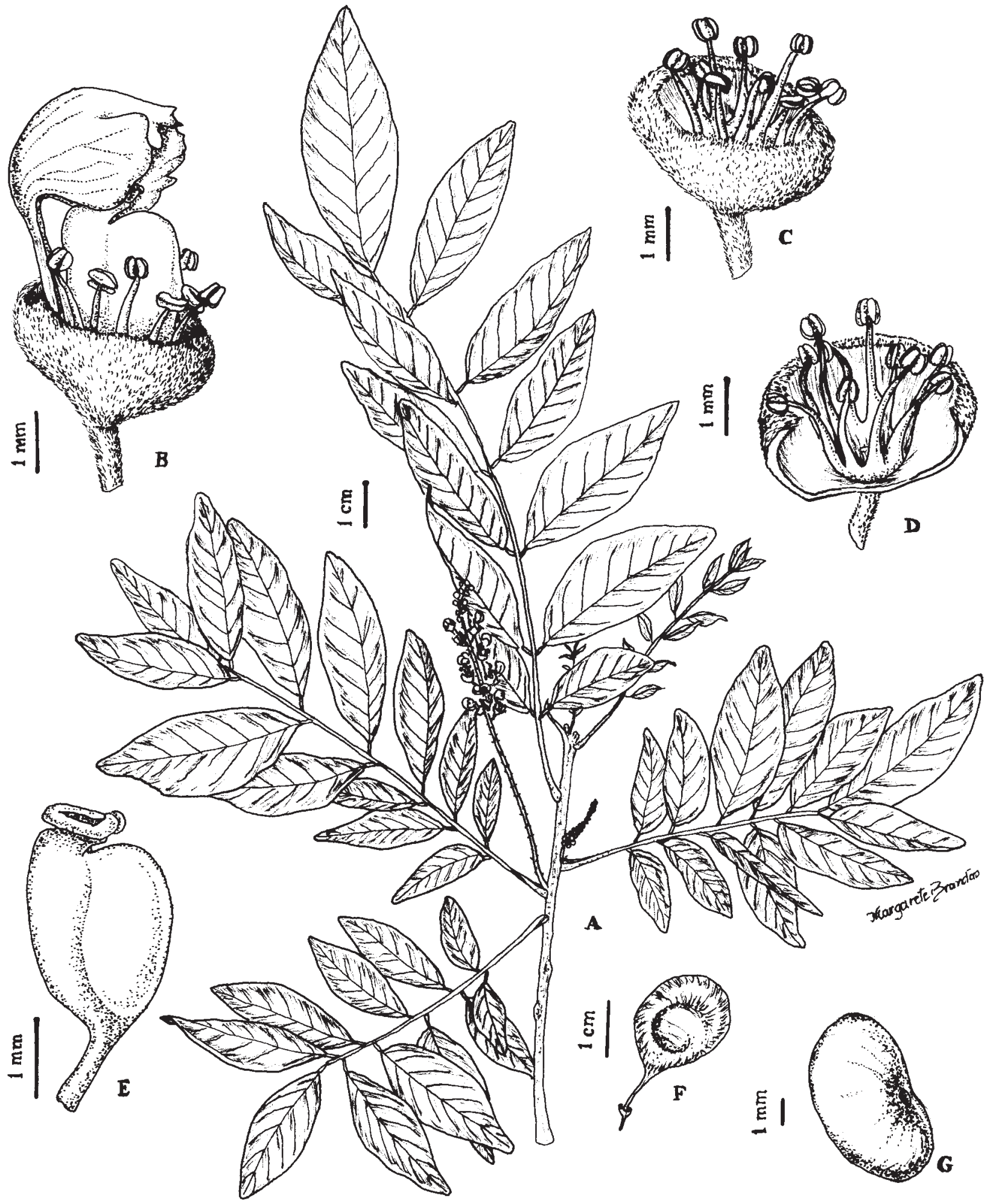
pecíolo 1-1,5 cm compr.; folíolos 1,3-4,5 × 0,5-1,5 cm, alternos a subopostos, elípticos a ovais, base aguda a oblíqua, ápice subagudo, faces dos folíolos jovens tomentosas, face adaxial do folíolo adulto glabra, face abaxial tomentosa a glabra. Inflorescências em racemos; pedúnculo 5-5,5 cm, eixo tomentoso-caduco, dourado-ferrugíneo; brácteas oval-acuminadas, tomentoso-ferrugíneas; cálice 3-3,5 mm compr., verde, lacínias obsoletas, tomentosas; pétala 1, cuculada, glabra, base longamente unguiculada; estames 10, filetes unidos na base; ovário estipitado, glabro; estilete tomentoso; estigma peltado, séssil. Legumes 2,8-3 cm compr., castanhos, estipitados, glabros; sementes elíptico-oblongas a reniformes, testa marrom-avermelhada.

Material examinado: BRASIL. Mato Grosso do Sul: Corumbá, Serra do Urucum, Planalto Residual do Urucum, 6-X-2003, fr., Silva \& Calisto 297 (UEC); 12-V-2004, fl., fr., Silva \& Iziel 938 (UEC); 17-XII-2004, fl., Silva \& Calisto 1348 (UEC); Serra Tromba dos Macacos, Planalto Residual do Urucum, 25-III-2004, fl., Silva \& Velásquez 851 (UEC); 28-IV-2004, fr., Silva \& Velásquez 912 (UEC); Serra Santa Cruz, Planalto Residual do Urucum, 17-XI-2003, fl., Silva \& Silva 567 (UEC); 17-II-2004, fl., Silva \& Silva 720 (UEC); 15-XII-2004, Silva \& Velásquez 1346 (UEC); Serra Grande, Planalto Residual do Urucum, 28-XII-2004, fl., Silva \& Velásquez 1377 (UEC).

No Brasil, ocorre nos estados de GO, MA, CE (Ireland 2001) e MS (Silva et al. 2007). No PRU, foi encontrada em florestas estacionais deciduais e semideciduais e em cerradão, entre 150 e 742 m.

7. Calopogonium Desv., Ann. Sci. Nat. 9: 423. 1826.

7.1. Calopogonium mucunoides Desv., Ann. Sci. Nat. 9: 423.1826.

Trepadeiras, 0,8-1,5 m alt. Ramos volúveis, hirsuto-ferrugíneos. Folhas 3-folioladas, pubescentes; pecíolo 2-5,5 cm compr.; folíolos terminais 1,5-4 × 0,9-2,9 cm, simétricos, oval-lanceolados, os laterais $1-3,5 \times 0,8-3 \mathrm{~cm}$, assimétricos, faces hirsutas, base obtusa, ápice agudo, margem ciliada. Inflorescências racemoso-fasciculadas, axilares, hirsutas; pedúnculo 10,7-30 cm compr.; brácteas e bractéolas subuladas, hirsutas; cálice 6-8 mm compr., verde, campanulado, lacínias subuladas, hirsutas; corola com pétalas lilases; estandarte 7-9 mm compr., oboval, auriculado, base unguiculada; alas 7-8 mm compr., estreitas, aderentes às pétalas da quilha; pétalas da quilha $6 \mathrm{~mm}$ compr., obtusas, menores que as asas; estames 10, diadelfos, 9 soldados até quase a metade do comprimento dos filetes, o vexilar livre; ovário séssil, hirsuto; estilete filiforme; estigma capitado, terminal. Legumes 2,5-4 cm compr., ferrugíneos, retos, hirsutos; sementes retangulares, testa castanha.

Material examinado: BRASIL. Mato Grosso do Sul: Corumbá, Serra do Urucum, Planalto Residual do Urucum, 3-VII-1993, Juerlene \& Edna s.n. (COR/2487); 7-X-2003, fl., fr., Silva \& Iziel 308 (UEC); Serra São Domingos, Planalto Residual do Urucum, 27-VII-2004, fr., Silva \& Velásquez 1007 (UEC); Serra Santa Cruz, Planalto Residual do Urucum, 23-VII-2004, fr., Silva \& Silva 991 (UEC); 10-IX-2004, fl., fr., Silva \& Silva 1125 (UEC).

No Brasil, ocorre nos estados de AP, PA, AM, AC, RO, MA, PI, CE, RN, PB, PE, BA, DF, MT, MS, MG, ES, SP e RJ (Carvalho-Okano \& Leitão Filho 1985, Lima 2010c) No PRU, foi coletada em floresta estacional semidecidual e campo cerrado, entre 518 e $787 \mathrm{~m}$ de altitude.

8. Camptosema Hook. \& Arn: Bot. Misc. 3: 200. 1823

\subsection{Camptosema ellipticum (Desv.) Burk., Darwiniana} 16(1-2): 210. 1970.

Trepadeiras a arbustos, 0,5-1,5 m alt. Ramos volúveis a eretos, pubérulos a glabrescentes. Folhas 3 -folioladas; pecíolo 1,5-5 cm compr.; folíolos coriáceos, os terminais 1,7-4,5 ×0,9-2,5 cm, elípticos a obovais, ápice arredondado a emarginado, base obtusa, os laterais 1,2-2,5 $\times 0,8-1,5 \mathrm{~cm}$, asssimétricos, face adaxial glabra, face abaxial pubescente. Inflorescências em pseudoracemos, axilares e terminais, nodosidades capitadas, sésseis; pedúnculo 4-9,5 cm compr.; cálice 6-11 mm compr., verde, tubuloso, esparsamente seríceo; corola com estandarte de 7-10 mm compr., externamente verde a vermelho, com guias cremes a vermelhas, oval, externamente pubescente, curvo, base unguiculada; alas 6-7 mm compr., vermelhas, oblongas, base unguiculada; pétalas da quilha 6-7 $\mathrm{mm}$ compr., vermelhas, oblongas, base unguiculada; estames pseudomonadelfos; ovário séssil, seríceo; estilete reto, glabro; estigma capitado. Legumes 2,7-3 cm compr., castanhos. oblongo-lineares, compressos, valvas coriáceas, castanhas, pubérulas; sementes oblongas, testa nigrescente, coriácea.

Material examinado: BRASIL. Mato Grosso do Sul: Corumbá, Serra do Urucum, Planalto Residual do 
Urucum, 20-VI-1999, fl., fr., Cunha 6 (COR); Serra do Jacadigo, Planalto Residual do Urucum, 28-XI-2003, fl., Silva \& Velásquez 469 (UEC); 30-VII-2004, fl., fr., Silva \& Velásquez 1039 (UEC); Serra Tromba dos Macacos, Planalto Residual do Urucum, 13-II-2003, fr., Silva \& Velásquez 269 (UEC); 25-III-2003, fl., Silva \& Velásquez 848 (UEC); 28-X-2003, fl., fr., Silva \& Velásquez 1237 (UEC); Serra São Domingos, Planalto Residual do Urucum, 27-VII-2004, fl., fr., Silva \& Velásquez 1011 (UEC); Serra Santa Cruz, Planalto Residual do Urucum, 17-I-2003, fl., Silva \& Velásquez 158 (UEC); 6-X-2003, fl., fr., Silva \& Silva 82 (UEC); 17-XII-2003, fl., Silva \& Velásquez 668 (UEC); 19-II-2004, fr., Silva \& Velásquez 727 (UEC); 23-VII-2004, fl., fr., Silva \& Silva 984 (UEC); 10-IX-2004, fl., Silva \& Silva 1123 (UEC); Serra Grande, Planalto Residual do Urucum, 24-III-2004, fl., Silva \& Velásquez 828 (UEC). Ladário, morro ao nordeste da fazenda Uruba, 2-VII-2001, fl., fr., Pott \& Pott 9257 (HMS); Serra do Rabichão, Planalto Residual do Urucum, 18-III-2004, fl., Silva \& da Silva 785 (UEC); 25-VIII-2004, fl., Silva \& da Silva 1088 (UEC).

No Brasil, ocorre nos estados de PA, RO, MA, GO, DF, MT, MS, MG, SP e PR (Queiroz 2010). No PRU, foi encontrada em florestas estacionais deciduais e semideciduais, cerrado, cerradão e campo cerrado, entre 175 e $900 \mathrm{~m}$ de altitude.

9. Canavalia DC., Prodr. 2: 403-404.1825.

9.1. Canavalia mattogrossensis (Barb. Rodr.) Malme, Ark. Bot. 4(7): 9. 1905.

Trepadeiras. Ramos volúveis, tomentosos. Folhas 3-folioladas, aderentes ao tato; pecíolo 4,5-5,5 cm compr.; estipelas lineares, estrigosas, caducas; folíolos laterais assimétricos; folíolo terminal, 10-12 × 6-8 cm, membranáceo, oblongo, base arredondada, ápice agudo, apiculado, face adaxial viloso-uncinada, face abaxial densamente subvilosa. Inflorescências em pseudoracemos, estrigosas; pedúnculo 15-20 cm compr.; brácteas ovallanceoladas, estrigosas; bractéolas ovais, estrigosas; cálice 5-7 mm compr., verde com pontuações vináceas, bilabiado, levemente giboso, lábio superior bilobado, lábio inferior trífido, estrigoso; corola azul; estandarte $15 \mathrm{~mm}$ compr., suborbicular, de ápice emarginado, base unguiculada, $8 \mathrm{~mm}$ compr., glabro; alas $14 \mathrm{~mm}$ compr., oblongo-lineares, glabras, auriculadas, base ungüiculada; pétalas da quilha $14 \mathrm{~mm}$ compr., obovais, cooalescentes no dorso, auriculadas, base unguiculada; estames 10, pseudomonadelfos; ovário estrigoso; estilete curvo, esparsamente subviloso; estigma capitado. Legumes 10-13 cm compr., castanho-amarelados, oblongos, deiscentes, nervura central crassa, denso-vilosa, indumento grisáceo-alvacento; sementes orbiculares, testa castanha.

Material examinado: BRASIL. Mato Grosso do Sul: Corumbá, Serra do Urucum, Planalto Residual do Urucum, 23-III-2004, fl., Silva \& Calisto 809 (UEC); 24-VII-2004, fr., Silva \& Iziel 1002 (UEC); Serra Tromba dos Macacos, Planalto Residual do Urucum, 28-IV-2004, fr., Silva \& Velásquez 913 (UEC); Serra São Domingos, Planalto Residual do Urucum, 27-VII-2004, fr., Silva 1006 \& Velásquez (UEC); Serra Santa Cruz, Planalto Residual do Urucum, 22-II-2004, fl., fr., Silva \& Ramires 735 (UEC); 31-III-2004, fl., Silva \& Silva 862 (UEC); 23-III-2004, fl., Silva \& Ramires 722 (UEC); Serra Grande, Planalto Residual do Urucum, 28-VII-2003, fr., Silva \& Velásquez 1023 (UEC).

No Brasil, ocorre nos estados de MT e MS (Sauer 1964). No PRU, foi encontrada em formações de floresta estacional semidecidual, cerrado e campo cerrado, 429 a $968 \mathrm{~m}$ de altitude.

10. Centrosema (DC.) Benth., Comm. Legum. Gen. 53: 1837.

\section{Chave para as espécies de Centrosema}

1. Folhas1-foliadas; folíolos oval-sagitados a deltóides; pecíolo alado ............. 10.3. C. sagittatum

1. Folhas 3-folioladas; folíolos ovallanceolados; pecíolo desprovido de ala 2. Inflorescências 2-floras; corola lilás 10.1. C. brasilianum

2. Inflorescências 5-floras; corola alva 10.2. C. pubescens

10.1. Centrosema brasilianum (L.) Benth., Comm. Legum. Gen.: 54. 1837.

Subarbustos, 20-50 cm alt. Ramos cilíndricos, volúveis a eretos. Folhas 3-folioladas; pecíolo 1-4 em compr.; folíolos 2,1-7,1 × 0,8-2,5 cm, oval-lanceolados, base arredondada, ápice obtuso, mucronado; estípulas 2,5-5 mm compr., triangulares a ovais; estipela 2-4 $\mathrm{mm}$ compr., setácea a linear-lanceolada. Inflorescências 2-floras; pedúnculo 0,5-2,4 cm compr; brácteas da base do pedúnculo estipuliformes, as do ponto de 
articulação oval-acuminadas, as da base do pedicelo oval-semiorbiculares, côncavas; bractéolas ovais a falcadas, pubérulas, ápice agudo a acuminado; cálice 8-11 mm compr., bilabiado, lábios vermelhos a ferrugíneos; lábio superior íntegro, ápice emarginado, lábio inferior com lacínias triangulares, ápice agudo a acuminado; corola lilás; estandarte 11-12 mm compr., externamente verde, internamente lilás, passando a vináceo, guias alvas, orbicular, ápice emarginado, pubescente; alas $11 \mathrm{~mm}$ compr., encurvadas, pubérulas; pétalas da quilha $12 \mathrm{~mm}$ compr., semiorbiculares, concrescidas em toda a extensão; estames 10 , diadelfos; ovário subséssil, pubescente; estilete esparsamente pubescente a glabro; estigma truncado. Legumes 7-12 cm compr., marrons, retos, pubérulos a glabrescentes; sementes oblongas, testa marmoreada.

Material examinado: BRASIL. MATo Grosso do SuL: Corumbá, Serra do Urucum, Planalto Residual do Urucum, 30-I-2003, fl., Silva \& Maciel 226 (UEC); Serra São Domingos, Planalto Residual do Urucum, 25-X-2004, fl., fr., Silva \& Velásquez 1228 (UEC); Serra Tromba dos Macacos, Planalto Residual do Urucum, 13-XII-2003, fl., Silva \& Velásquez 268 (UEC); Serra Santa Cruz, Planalto Residual do Urucum, 7-II-2003, fl., Silva \& Ramires 239 (UEC).

No Brasil, ocorre nos estados de RR, AP, PA, AM, MA, PI, CE, RN, PB, PE, BA, AL, SE, MT, GO, DF, MS, MG, SP, RJ, PR e SC (Souza 2010). No PRU, foi coletada em fitofisionomia de floresta estacional decidual e campo cerrado, entre 175 e $990 \mathrm{~m}$ de altitude.

\section{2. Centrosema pubescens Benth., Comm. Legum.}

Gen: 55. 1837.

Trepadeiras. Ramos volúveis, angulosos, glabrescentes. Folhas 3-folioladas; pecíolo 2,5-4 cm compr., estípulas $4 \mathrm{~mm}$ compr., triangulares a ovais, acuminadas a agudas, pubescentes a subglabras; estipelas $2 \mathrm{~mm}$ compr., setáceas a lineares, pubérulas; folíolos laterais asimétricos; folíolo terminal 7,3-10 × 4,5-7 cm, rígido-membranáceos, ovallanceolados, base obtusa a aguda, ápice acuminado, agudo a obtuso, face adaxial hirsuto-tomentosa a subglabra nas nervuras, face abaxial pubescente a subglabra. Inflorescências axilares, 5-floras; pedúnculo 2,5-3,8 cm compr., hirsuto-tomentoso a glabrescente; brácteas do ápice do pedúnculo estipuliformes, as da base ovais, rígido-membranáceas, agudas a acuminadas; cálice 7-9 $\mathrm{mm}$ compr., verde, lacínias superiores triangulares, agudas a obtusas, coalescentes até quase a metade, pubérulas, oblongas a lineares; lacínias inferiores lanceoladas, as centrais lanceoladas; corola alva; estandarte 20-25 mm compr., alvo com manchas violáceas, orbicular, pubescente; alas 17-19 mm compr., sigmóides; pétalas da quilha 16-19 mm compr., suborbiculares; estames 10, diadelfos; ovário subséssil; estilete glabro; estigma truncado, barbado. Legumes 10-12 cm compr., castanhos, retos, pubérulos a glabrescentes; sementes oblongas, testa marmoreada.

Material examinado: BRASIL. Mato Grosso do Sul: Corumbá, Serra Santa Cruz, Planalto Residual do Urucum, 7-VII-2005, fl., fr., Silva \& Marcos 1384 (UEC).

No Brasil, ocorre nos estados de PA, AM, AC, RO, MA, PI, CE, PB, PE, BA, AL, MT, GO, MS, MG, SP, RJ e PR (Souza 2010). No PRU, ocorre em cerradão, a $690 \mathrm{~m}$ de altitude.

10.3. Centrosema sagittatum (Humb. \& Bonpl. ex Willd.) Brandegee ex L. Riley, Bull. Musc. Inform. Kew 1923(9): 344. 1923.

Ervas, 15-70 cm alt. Ramos angulosos, eretos a prostrados, hirsutos a glabrescentes. Folhas 1-folioladas; pecíolo 4-7 cm compr., alado, alas na região mediana estreitadas do ápice em direção à base; estípulas 3-4 mm compr., ovais a triangulares, glabrescentes; estipelas $3 \mathrm{~mm}$ compr., linearlanceoladas, subfalcadas, esparso-hirsutas a glabrescentes; folíolos oval-sagitados a deltóides, ápice acuminado, base sagitada, ambas as faces esparso-hirsutas a esparso-pubescentes nas nervuras e vênulas. Inflorescências pedunculadas, 2-5-floras; pedúnculo 1,5-2,5 cm compr.; brácteas estipuliformes; bractéolas ovais a semiorbiculares; cálice 8-9 mm compr., verde, tubuloso, lacínias inferiores lanceoladas divergentes; corola lilás a rósea; estandarte orbicular, externamente pubescente; alas sigmóides; pétalas da quilha semiorbiculares; ovário subséssil; estilete glabro; estigma truncado. Legumes 7-8 cm compr., castanhos, retos a subfalcados; sementes oblongas, testa castanha.

Material examinado: BRASIL. Mato Grosso do Sul: Corumbá, Serra do Jacadigo, Planalto Residual do Urucum, 20-IX-2004, fr., Silva \& Velásquez 1134 (UEC); Serra Urucum, Planalto Residual do Urucum, 17-XII-2004, fr., Silva \& Iziel 1351 (UEC). Serra Tromba dos Macacos, Planalto Residual do Urucum, 
25-III-2004, fl., Silva \& Velásquez 834 (UEC); Serra São Domingos, Planalto Residual do Urucum, 22-III-2004, fl., Silva \& Velásquez 789 (UEC); 30-XII-2004, fr., Silva \& Velásquez 1382 (UEC); Serra Santa Cruz, Planalto Residual do Urucum, 15-XII-2004, fr., Silva \& Sebastião 1341 (UEC); Serra Grande, Planalto Residual do Urucum, 27-IV-2004, fl., Silva \& Velásquez 897 (UEC).

No Brasil, ocorre nos estados de CE, PB, PE, BA, GO, MS, MG, ES, SP, RJ e PR (Souza 2010). No PRU, foi encontrada em florestas estacionais deciduais e semideciduais e cerradão, entre 127 e 699 m de altitude.

\section{Chaetocalyx DC., Prodr.2: 243.1825.}

\subsection{Chaetocalyx brasiliensis (Vogel) Benth., Fl.} Bras. 15(1A): 75. 1859.

Trepadeiras, 2,5 m alt. Ramos estriados, pubescentes. Folhas 5-11-folioladas; pecíolo 2-3 mm compr.; estípulas deltóide-lanceoladas, pubescentes a subglabras, setoso-ciliadas; folíolos elípticos, suborbiculares a obovais, base arredondada, ápice obtuso a truncado, emarginado, mucronulado, ambas as faces pubescentes. Inflorescências em racemos, axilares; pedúnculo 2-3 cm compr.; brácteas ovaldeltóides, setosas, alargadas na base; cálice 12-13 mm compr., verde, campanulado, giboso, ápice ciliado, setoso a subglabro; estandarte $11 \mathrm{~mm}$ compr., oboval, de ápice emarginado e ciliado, base unguiculada; alas $8 \mathrm{~mm}$ compr., oblongas, esculturadas, auriculadas, base unguiculada, ápice e margem ciliados; pétalas da quilha $9 \mathrm{~mm}$ compr., coalescentes na metade do dorso, auriculadas, base unguiculada, ápice e margem ciliado-glandulosos; estames 10, monadelfos; ovário estipitado, subviloso, indumento amarelo; estilete curvado; estigma subcapitado. Lomentos 10-20 cm compr., amarelos a cinza-escuros, subcilíndricos, longitudinalmente estriados, 12-16 articulados; artículos uniformes, hirsutos; sementes oblongas, testa castanha a acinzentada.

Material examinado: BRASIL. MAto Grosso do SuL: Ladário, Serra do Rabichão, Planalto Residual do Urucum, 14-XI-2003, fl., fr., Silva \& Silva 557 (UEC).

No Brasil, ocorre nos estados de PA, AC, GO, MS, PR e SC (Rudd 1958). No PRU, foi coletada em fitofisionomia de floresta estacional decidual, a $400 \mathrm{~m}$ de altitude.
12. Clitoria L., Sp. Pl. 2: 753. 1753.

Chave para as espécies de Clitoria

1. Folhas com 1-3 folíolos no mesmo indivíduo; face adaxial glabra ..... 12.1. C. densiflora

1. Folhas sempre 3-folioladas; face adaxial com microtricomas uncinados 12.2. C. guiannensis

12.1 Clitoria densiflora Benth., J. Proc. Linn. Soc. Bot. 2: 41. 1858 .

Subarbustos, ca. $60 \mathrm{~cm}$ alt. Ramos sulcados, estriados, pubescentes. Folhas 1-3-folioladas no mesmo indivíduo; pecíolo 3-5 mm compr.; estípulas 5-14 mm compr., oblongo-acuminadas a setáceas, multinervadas, tomentosas, com microtricomas uncinados; estipelas 5-12 mm compr.; folíolos 3,5-10,5 × 1,7-6 cm, os da base 1-foliados, os terminais 3-foliolados, oboval-oblongos, base aguda, ápice agudo a arredondado, face adaxial glabra, face abaxial sedoso-subvilosa. Inflorescências axilares, 2-floras; pedúnculo 1-3,7 cm compr.; brácteas ovais, estriadas; bractéola $15 \mathrm{~mm}$ compr., lanceolada, estriada, ciliada; cálice 4-4,7 cm compr., verde, infundibuliforme, nervado, subviloso-glabrescente; corola creme; estandarte $30 \mathrm{~mm}$ compr., suborbicular, externamente creme, pubescente-uncinado, internamente com guias vináceos, glabro, base unguiculada; alas $25 \mathrm{~mm}$ compr., elípticas, base unguiculada; pétalas da quilha $24 \mathrm{~mm}$ compr., elípticas, base unguiculada; estames 10, diadelfos; ovário estipitado; estilete achatado, dilatado, barbado; estigma terminal. Legumes 3,5-6 cm compr., linear-falcados, estipitados, castanhos, seríceo-tomentosos; sementes globosas, testa castanho-escura.

Material examinado: BRASIL. Mato Grosso do Sul: Corumbá, Serra Santa Cruz, Planalto Residual do Urucum, 25-X-2003, fl., fr., Silva \& Sebastião 435 (UEC).

No Brasil, ocorre nos estados de GO, MT, MS, MG, SP e PR (Rando \& Souza 2010). No PRU, ocorre em formação de campo cerrado, a $990 \mathrm{~m}$ de altitude.

12.2. Clitoria guianensis (Aubl.) Benth., J. Proc. Linn. Soc. 2: 40. 1858.

Subarbustos, 10-30 cm alt. Ramos cilíndricos, glabrescentes. Folhas 3-folioladas; pecíolo 8-18 mm compr.; estípulas 5-7 mm compr., lanceoladas a deltóides; estipelas lineares a subuladas; folíolos 
6-14 $\times 0,6-1,5 \mathrm{~cm}$, linear-oblongos a lineares, base cuneada, ápice agudo, mucronado, face adaxial reticulada, com microtricomas uncinados, face abaxial glauca, reticulada, glabrescente e com tricomas-uncinados sobre as nervuras. Inflorescências axilares, 1-2-floras; pedúnculo 7-7,2 cm compr.; brácteas deltóides; cálice 2,5-3,5 cm compr., verde com manchas lilases, campanulado, 5-laciniado, lacínias triangulares; corola creme a lilás, ressupinada; estandarte $50 \mathrm{~mm}$ compr., externamente creme, internamente lilás com mancha central amarela e guias vináceas, suborbicular, base subulada, unguiculada, ápice truncado, margem pubérula; alas $45 \mathrm{~mm}$ compr., glabras, base unguiculada, ápice truncado; pétalas da quilha $40 \mathrm{~mm}$ compr., obovais, glabras, base unguiculada; estames 10, diadelfos; ovário estipitado, glabro; estilete encurvado, filiforme, barbado; estigma punctiforme. Legumes $5 \mathrm{~cm}$ compr., castanhos, linear-falcados, estipitados, com nervuras longitudinais proeminentes; sementes globosas, testa castanha.

Material examinado: BRASIL. MAto Grosso do Sul: Corumbá, Serra do Jacadigo, Planalto Residual do Urucum, 22-X-2004, fl., fr., Silva \& Velásquez 1198 (UEC); Serra Urucum, Planalto Residual do Urucum, 22-I-2003, fl., Silva \& Calisto 169 (UEC); 22-XII-2003, fl., fr., Silva \& Iziel 708 (UEC); 27-X-2004, fl., fr., Silva \& Filho 1259 (UEC); Serra Tromba dos Macacos, Planalto Residual do Urucum, 27-I-2003, Silva \& Velásquez 192 (UEC); 13-II-2003, fl., Silva \& Velásquez 274 (UEC); 28-XI-2003, fl., Silva \& Velásquez 481 (UEC); Serra Santa Cruz, Planalto Residual do Urucum, 31-X-2003, fl., fr., Silva \& Velásquez 519 (UEC).

No Brasil, ocorre nos estados de RR, AP, PA, AM, TO, MA, PI, CE, PE, BA, MT, GO, DF, MS, MG, ES, SP e PR (Rando \& Souza 2010). No PRU, foi coletada em formação de campo cerrado, entre 726 e 994 m de altitude.

13. Coursetia DC., Ann. Sci. Nat. (Paris) 4: 92. 1825.

\subsection{Coursetia hassleri Chodat, Bull. Herb. Boissier,} ser. 2, 4(9): 880. 1904.

Figura 4

Subarbustos, 0,5-1,3 m alt. Ramos eretos a ascendentes, glabros. Folhas paripinadas, 5-9-folioladas; pecíolo 3-9 mm compr.; estípulas 2-10 mm compr., subuladas, persistentes; folíolos 0,9-3,8 $\times 0,5-1,4 \mathrm{~cm}$, opostos a subopostos, elípticos, base aguda a arredonda, ápice agudo ou arredondado, mucronado, ambas as faces vilosas. Inflorescências em racemos axilares, eixo tomentoso-caduco; brácteas lanceoladas, caducas; cálice 2-4 mm compr., verde, campanulado, arredondado na base, estrigoso, lacínias 5, lanceoladas; corola alva a rósea; estandarte 8-11 mm compr., orbicular, com aurículas inflexas e calosidades na base, com guias de néctar verdes, base unguiculada, ápice emarginado; alas 8-12 mm compr., oblongas, curtamente auriculadas, esculturadas, base unguiculada; pétalas da quilha 8-11 mm compr., oblongas, curvas, curtamente auriculada, base unguiculada; estames 10, diadelfos; ovário subséssil, granulífero, glabro; estilete curvo, pubescente; estigma capitado. Legumes 4,5-7 mm compr., castanhos a marrom-escuros, curto-estipitados, glabros; sementes quadrangulares, testa castanha, mosqueada a marrom.

Material examinado: BRASIL. Mato Grosso DO Sul: Corumbá, Serra do Jacadigo, Planalto Residual do Urucum, 27-III-2004, fl., Silva \& Velásquez 857 (UEC); Serra do Urucum, Planalto Residual do Urucum, 12-V-2004, fl., Silva 946 \& Filho (UEC); Serra Tromba dos Macacos, Planalto Residual do Urucum, 20-XII-2004, fl., Silva \& Velásquez 1362 (UEC); Serra São Domingos, Planalto Residual do Urucum, 26-IV-2004, fl., fr., Silva \& Velásquez 896 (UEC); Serra Santa Cruz, Planalto Residual do Urucum, 17-XII-2003, fl., Silva \& Velásquez 157 (UEC); Serra Grande, Planalto Residual do Urucum, 24-III-2004, fr., Silva \& Velásquez 820 (UEC); 28-VII-2004, fl., fr., Silva \& Velásquez 1027 (UEC). Ladário, Serra do Rabichão, Planalto Residual do Urucum, 16-III-2004, fl., fr., Silva \& Silva 765 (UEC); 21-IV-2004, fl., fr., Silva \& Silva 886 (UEC).

No Brasil, ocorre no estado de MS (Lavin 1988). No PRU, ocorre em fitofisionomia de floresta estacional decidual, entre 100 e $429 \mathrm{~m}$ de altitude.

14. Crotalaria L., Sp. P1., 2: 714. 1753.

Chave para as espécies de Crotalaria

1. Folhas simples; ala internodal

decorrente presente 14.3. C. stipularia

1. Folhas digitadas, 3-folioladas; ala internodal ausente

2. Vexilo com estrias vermelhas; legume pêndulo, hirsuto; semente oblíquo-reniforme 14.1. C. incana

2. Vexilo com estrias pretas; legume ereto a patente, pubérulo; semente oblíquo-cordiforme a subcordiforme 14.2. C. micans 


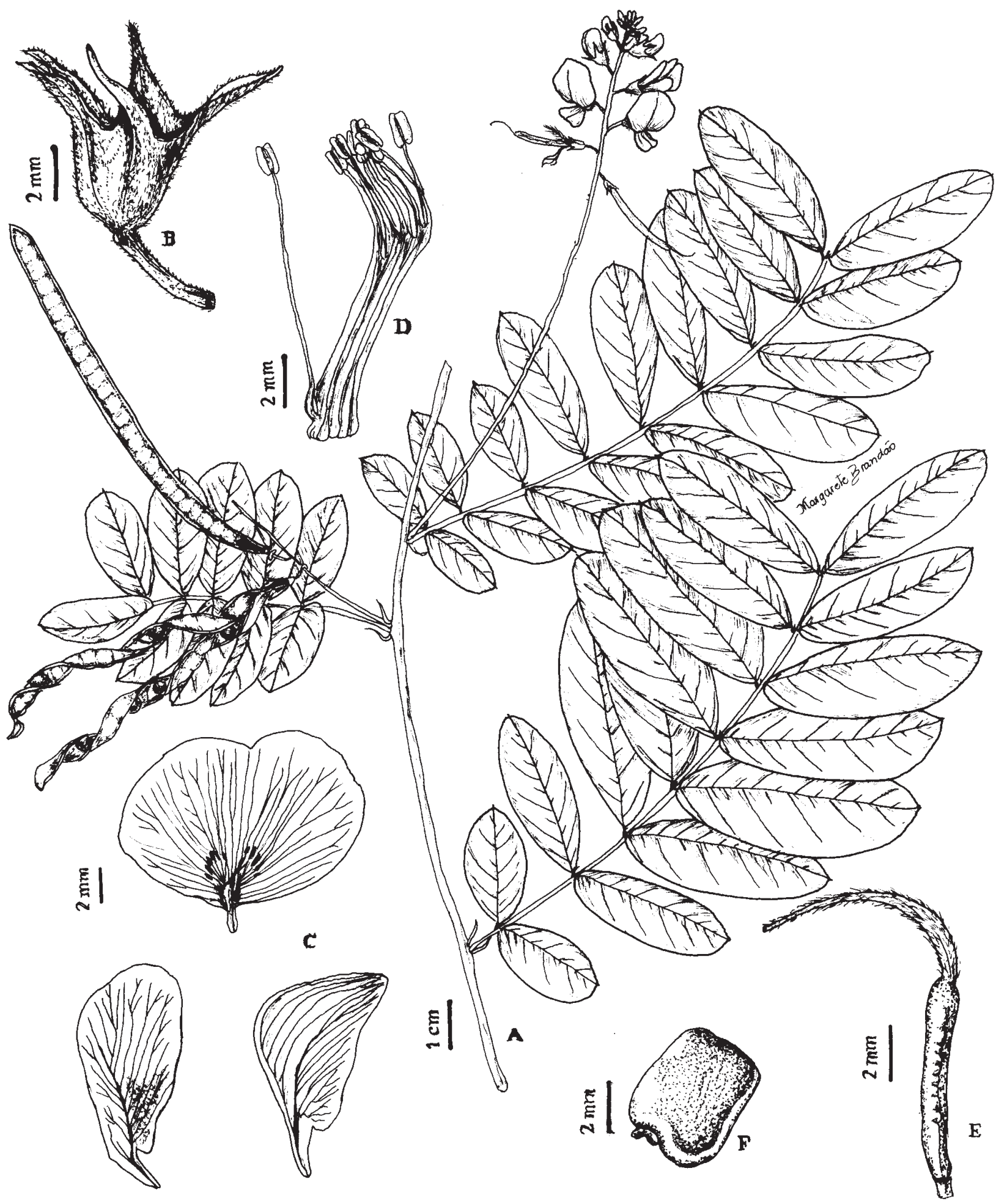

Figura 4. Coursetia hassleri. A. Ramo com inflorescência e frutos. B. Cálice. C. Pétalas: vexilo (acima), asa (à esquerda) e carena (à direita). D. Androceu. E. Gineceu. F. Semente (A, F: R.R. Silva \& J.S. Velásquez 820; B-E: R.R. Silva \& J.S. Velásquez 857, UEC).

Figure 4. Coursetia hassleri. A. Branch with inflorescence and fruits. B. Calyx. C. Petals: standard (above), wing (on the left) e keel petals (on the right). D. Androecium. E. Gynoecium. F. Seed (A, F: R.R. Silva \& J.S. Velásquez 820; B-E: R.R. Silva \& J.S. Velásquez 857, UEC). 


\subsection{Crotalaria incana L., Sp. P1. 2: 716. 1753.}

Subarbustos, 0,2-1 m alt. Ramos cilíndricos, velutinos a hirsutos, com tricomas patentes a adpressos. Folhas digitadas, 3-folioladas, longo-pecioladas; pecíolo 1,5-7 cm compr.; folíolos 1,3-5,7 × 0,8-4 cm, oboval-elípticos a obovais, base cuneada, ápice arredondado e mucronado, glabrescentes em ambas as faces; estípulas 2-4 mm compr., subuladas, livres, pubescentes, caducas. Ala internodal ausente. Inflorescências em racemos terminais ou opositifólios, 5-20-floras; pedúnculo 1,7-4,5 cm compr.; brácteas subuladas, persistentes; bractéolas subuladas, persistentes, inseridas no ápice do pedicelo; cálice 8-12 mm compr., verde, campanulado, lacínias subiguais, às vezes mais longas que o tubo, pubescentes; corola amarela; estandarte 10-13 mm compr., com estrias vermelhas, orbicular a oboval, base com apêndices estendidos até a unguícula, ápice emarginado; alas 9-12 mm compr., obovais; pétalas da quilha 11-13 mm compr., subangulares a arredondadas, com ápice pouco prolongado, não torcido; estames 10, monadelfos; ovário estipitado a séssil, tomentoso; estilete curvo; estigma barbado. Legumes 2,9-3,5 cm compr., castanho-escuros, pêndulos, cilíndricooblongos, curto-estipitados, hirsutos; sementes oblíquo-reniformes, testa castanho-escura.

Material examinado: BRASIL. MAto Grosso DO Sul: Corumbá, Serra do Urucum, Planalto Residual do Urucum, 28-I-2003, Silva \& Maciel 197 (UEC); 7-X-2003, fl., Silva \& Calisto 306 (UEC); Serra do Jacadigo, Planalto Residual do Urucum, 8-II-2003, fr., Silva \& Velásquez 247 (UEC); Serra São Domingos, Planalto Residual do Urucum, 20-XI-2003, fl., Silva \& Velásquez 575 (UEC); Serra Santa Cruz, Planalto Residual do Urucum, 9-I-2003, fl., fr., Silva \& Silva 110 (UEC); 17-XII-2003, fl., fr., Silva \& Velásquez 669 (UEC); 10-IX-2004, fr., Silva \& Silva 1126 (UEC). Ladário, Serra do Rabichão, Planalto Residual do Urucum, 17-X-2003, fl., Silva \& Silva 357 (UEC); 11-XII-2003, fl., fr., Silva \& Silva 642 (UEC); 20-V-2004, fl., Silva \& Silva 959 (UEC).

No Brasil, ocorre nos estados de PA, AM, AC, PI, CE, BA, GO, DF, MS, MG, ES, SP, RJ, PR, SC e RS (Flores 2004). No PRU, foi encontrada em florestas estacionais deciduais e semideciduais, entre $121 \mathrm{e}$ $711 \mathrm{~m}$ de altitude.

14.2. Crotalaria micans Link, Enum. P1. Hort. Berol 2: 228.1822.

Arbustos, 0,8-2,4 $\mathrm{m}$ alt. Ramos cilíndricos, eretos, pubérulos. Folhas digitadas, 3-folioladas, longo-pecioladas; pecíolo 3-7 cm compr.; estípulas 2-6 mm compr., subuladas, pubescentes, caducas; folíolos 3,5-7,8 × 0,9-2,5 cm, oboval-elípticos a oblongo-elípticos, base cuneada, ápice acuminado, mucronado, ambas as faces pubescentes. Ala internodal ausente. Inflorescências em racemos terminais a opositifólios, 10-25-floras; pedúnculo 0,6-6,4 cm compr.; brácteas subuladas, caducas; bractéolas subuladas, caducas; cálice $0,8-1 \mathrm{~cm}$ compr., verde, campanulado, pubescente, lacínias subiguais, duas vezes mais longas que o tubo; corola amarela; estandarte 13-20 mm compr., com guias pretas, suborbicular a oboval, base com apêndices estendidos até a unguícula, ápice emarginado; alas 13-16 mm compr., com estrias avermelhadas, obovais, curvas; pétalas da quilha $10-16 \mathrm{~mm}$ compr., com estrias avermelhadas, falcadas, ápice encurvado e não torcido; estames 10, monadelfos; ovário estipitado, pubescente; estilete curvo; estigma barbado. Legumes 2,8-4 cm compr., castanhos a preto-rajados, oblongos, estipitados, pubérulos, eretos a patentes; sementes oblíquo-cordiformes a subcordiformes, testa castanha a alaranjada.

Material examinado: BRASIL. Mato Grosso do Sul: Corumbá, Serra do Urucum, Planalto Residual do Urucum, 22-I-2003, fl., Silva \& Calisto 165 (UEC); 31-III-2003, fl., Silva \& Calisto 233 (UEC); 13-X-2003, fl., Silva \& Filho 324 (UEC); Serra Tromba dos Macacos, Planalto Residual do Urucum, 13-II-2003, fl., Silva \& Velásquez 271; 28-X-2003, fl., Silva \& Velásquez 468 (UEC); 19-XII-2003, fl., Silva \& Velásquez 695 (UEC); 28-IV-2004, fr., Silva \& Velásquez 910 (UEC); Serra Santa Cruz, Planalto Residual do Urucum, 19-II-2004, fl., Silva \& Silva 723 (UEC); 23-VII-2004, fr., Silva \& Silva 992 (UEC).

No Brasil, ocorre nos estados de RR, AP, PA, AM, AC, PE, BA, MT, GO, DF, MS, MG, SP, RJ, PR, SC e RS (Flores 2010). No PRU, foi coletada em fitofisionomia de floresta estacional decidual, cerrado, campo cerrado e cerradão, entre 150 e 945 m de altitude.

14.3. Crotalaria stipularia Desv., J. Bot. Agric. 3: 76. 1814.

Subarbustos, 10-60 cm alt. Ramos cilíndricos, eretos ou prostrados, pubescentes a seríceos. Folhas simples, sésseis, oblongas, oval-lanceoladas a elípticas, base cuneada, ápice agudo a arredondado, mucronado, ambas as faces seríceas; estípulas ausentes. Ala internodal decorrente, parte livre falcada. Inflorescências racemosas, internodais, 2-5-floras; 
pedúnculo 30-55 cm compr.; brácteas lineares a elíptico-lanceoladas, persistentes; bractéolas lineares a elíptico-lanceoladas, inseridas na base do cálice; cálice 8-11 mm compr., verde, campanulado, bilabiado, seríceo, superando a corola, lacínias superiores unidas até a metade, as inferiores unidas ou não no ápice; estandarte 7-8 mm compr., obovado, ápice emarginado a arredondado, base com apêndices lameriformes restritos à lâmina; alas 6-8 $\mathrm{mm}$ compr., obovais; pétalas da quilha 6-8 mm compr., subangulares a arredondadas, com ápice pouco prolongado, torcido; estames 10, monadelfos; ovário curtamente estipitado, glabro, estilete geniculado na base; estigma barbado. Legumes 2,2-3,6 cm compr., pretos, oblongos a obovais, subsésseis, pêndulos, glabros; sementes oblíquo-reniformes, testa castanho-escura.

Material examinado: BRASIL. Mato Grosso do Sul: Corumbá, Serra São Domingos, Planalto Residual do Urucum, 26-XI-2004, fl., Silva \& Velásquez 1327 (UEC); Serra Santa Cruz, Planalto Residual do Urucum, 31-III-2004, fr., Silva \& Silva 860 (UEC); 15-XII-2004, fl., fr., Silva \& Silva 1344 (UEC).

No Brasil, ocorre nos estados de RR, PA, AC, MA, PI, CE, PB, PE, BA, AL, SE, MT, GO, DF, MS, MG, ES, SP e RJ (Flores 2010). No PRU, foi encontrada em fitofisionomia de floresta estacional semidecidual e cerrado, entre 527 e 703 m de altitude.

15. Desmodium Desv., J. Bot. Agric. 1: 122. 1813.

Chave para as espécies de Desmodium

1. Folhas sempre 3-folioladas; estípulas verdes, castanhas a marrons, não amplexicaules

2. Erva rasteira; lomento com 4-6 artículos 15.1. D. affine

2. Trepadeira; lomento com 1-2 artículos 15.2.D. axillare

3. Inflorescência racemosa 15.5.D. incanum

3. Inflorescência paniculada

4. Folíolos concolores; cálice com manchas roxas ........ 15.6. D. tortuosum

4. Folíolos discolores; cálice sem manchas roxas 15.3. D. discolor

1. Folhas 1-3-folioladas; estípulas amarelas, quase amplexicaules 15.4.D. distortum

15.1. Desmodium affine Schltd1., Linnaea 12: 312-313. 1838.

Ervas, ca. $40 \mathrm{~cm}$ alt. Ramos estriados, pubescenteuncinados. Folhas 3-folioladas; pecíolo 2-5 cm compr.; estípulas 2-4 mm compr., ovais, livres, marrons, base auriculada, ápice acuminado; estipela 2-3 mm compr., linear-triangular; folíolos 3-8,5 × 1,5-4 cm, discolores, ovais, base arredondada, ápice agudo, face adaxial pubescente na nervura principal, face abaxial densopubescente. Inflorescências em racemos terminais, eixos pubescentes, com tricomas uncinados; pedúnculo 6-14 cm compr.; bractéas ovais, castanhas, pubérulas, com tricomas uncinados, ciliadas, caducas; cálice $6 \mathrm{~mm}$ compr., verde, lacínias desiguais, pubescenteuncinado; corola alva; estandarte 10-11 mm compr., oboval, base curtamente unguiculada, margem com microtricomas uncinados; alas 8-9 mm compr., obovais, glabras; pétalas da quilha $8 \mathrm{~mm}$ compr., obovais; estames 10, monadelfos; ovário lateralmente pubescente; estilete curvo, glabro; estigma terminal, glabro. Lomentos verdes quando maduros, estipitados, com sutura crenada, ístmos marginais, 4-6 articulados; artículos 5-7 mm compr., semi-elípticos, com tricomas amarelos, uncinados; sementes reniformes, testa castanha.

Material examinado: BRASIL. MAto Grosso Do Sul: Corumbá, Serra Santa Cruz, Planalto Residual do Urucum, 13-III-2001, fl., fr., Damasceno Jr. 2227 (COR).

No Brasil, ocorre nos estados da BA, CE, MA, MG, PR, RJ, RS, SC, SP e PA (Azevedo 1981), sendo também citada para o estado de MS (Silva et al. 2007). No PRU, foi encontrada em fitofisionomia de floresta estacional semidecidual.

15.2 Desmodium axillare (Sw.) DC., Prodr. 2: 333. 1825.

Trepadeiras, ca. $30 \mathrm{~cm}$ alt. Ramos estriados, pubescente-uncinados. Folhas 3-folioladas; pecíolo 2-8 mm compr.; estípulas 4-9 mm compr., marromavermelhadas, ovais, coalescentes até a metade do seu comprimento, acuminadas, estriadas, pubescentes a glabrescentes, ciliadas, base auriculada a reta; estipela 2-6 mm compr., linear-triangular, pubérula, ciliada; folíolos 3-10 × 2-5 cm, subovais, ovais a subdeltóides, base obtusa, ápice agudo, mucronulado, papiráceo, ciliado, face adaxial verde-escura, esparsoestrigosa, face abaxial verde-acinzentada, velutína. Inflorescências em racemos, axilares, alongadas, com eixo castanho-amarelado a verde-vináceo, quase negro, pubérulo-uncinado; pedúnculo $6-18 \mathrm{~cm}$ compr., brácteas ovais, estriadas, acuminadas, ciliadas, caducas; bractéolas ovais, caducas; cálice 1-1,5 mm compr., verde-arroxeado a roxo, bilabiado, pubescente 
a pubérulo, com microtricomas uncinados, lacínias desiguais, as do lado superior coalescentes até quase o ápice; corola com pétalas róseo-escuras a róseas; estandarte 4-8 mm compr., oboval, ápice retuso, com guias amarelo-esverdeadas; alas 3-6 mm compr., obovais; pétalas da quilha 3-5 mm compr., obovais, unidas até a metade do seu comprimento; estames 10 , monadelfos; ovário pubérulo-viloso; estilete curvo, glabro; estigma terminal, glabro. Lomentos verdes, longo-estipitados, 1-2-articulados, sutura superior côncava, região do istmo marginal espessada; artículos 5-7 mm compr., subelípticos, pubérulo-uncinados; sementes reniformes, testa castanha.

Material examinado: BRASIL. Mato Grosso Do Sul: Corumbá, Serra do Urucum, Planalto Residual do Urucum, 29-XII-2004, fl., fr., Silva \& Calisto 1379 (UEC); Serra São Domingos, Planalto Residual do Urucum, 30-XII-2004, fl., fr., Silva \& Velásquez 1381 (UEC); Serra Tromba dos Macacos, Planalto Residual do Urucum, 29-X-2004, fl., Silva \& Velásquez 1380 (UEC); Serra Santa Cruz, Planalto Residual do Urucum, 10-II-2003, fl., fr., Silva \& Silva 257 (UEC); Serra Santa Cruz, Planalto Residual do Urucum, 17-II-2004, fl., fr., Silva \& Silva 719 (UEC); 10-XI-2003, fl., fr., Silva \& Silva 527 (UEC); 10-XI-2004, fl., fr., Silva \& Silva 1270 (UEC); 15-XII-2004, fl., fr., Silva \& Silva 1340 (UEC).

No Brasil, ocorre nos estados de RR, AP, PA, AM, AC, RO, MA, CE, PR, MT, GO, DF, MS, MG, ES, SP e RJ (Azevedo 1981, Lima \& Oliveira 2010b). No PRU, foi encontrada em áreas de floresta estacional semidecidual e cerradão, entre 699 e $947 \mathrm{~m}$ de altitude.

15.3. Desmodium discolor Vogel, Linnaea 12: 103. 1838.

Arbustos, 0,5-1,8 m alt. Ramos cilíndricos, vilosos, aderentes ao tato. Folhas 3-folioladas; pecíolo 6-7 mm compr.; estípulas $3 \mathrm{~mm}$ compr., oblíquas, castanhas, livres a unidas na base, base dilatada, ápice acuminado; estipela 2-3 mm compr., subulada a setácea, estriada; folíolos 3-10 × 2-5,5 cm compr., ovais a obovais, base subarredondada, ápice obtuso, face adaxial uncinado-pubérula, pálida, nervuras primárias e secundárias amareladas, face abaxial vilosa, com tricomas ferrugíneos. Inflorescências paniculadas, terminais, densifloras; pedúnculo $15-20 \mathrm{~cm}$ compr.; brácteas ovais, externamente seríceas, caducas, ápice acuminado e ciliado; cálice 2-3 mm compr., verde, bilabiado, lacínias do lábio superior soldadas quase inteiramente, as do lábio inferior trífidas, lacínias centrais mais longas, pubescentes; corola vinácea a lilás; estandarte $5 \mathrm{~mm}$ compr., oboval, glabro, com mancha mais escura no terço inferior, glabro; alas $4 \mathrm{~mm}$ compr., glabras; pétalas da quilha 3-4 mm compr., glabras; estames 10, monadelfos; ovário subséssil, pubescente; estilete curvo, glabro; estigma terminal, glabro. Lomentos castanho-amarelados a pardacentos, curtamente estipitados a sésseis, 4-7-articulados; artículos 2-3 mm compr., orbiculares, reticulados, margens espessadas, glabras, com ístmo central; sementes reniformes, testa castanha.

Material examinado: BRASIL. Mato Grosso do Sul: Corumbá, Serra São Domingos, Planalto Residual do Urucum, 22-III-2004, fl., fr., Silva \& Velásquez 804 (UEC); 25-X-2004, fr., Silva \& Velásquez 1227 (UEC). Ladário, Serra do Rabichão, Planalto Residual do Urucum, 18-III-2004, fl., fr., Silva \& Silva 768 (UEC).

No Brasil está citada para os estados de AC, MT, GO, DF, MS, MG, SP, RJ, SC e RS (Azevedo 1981), e Mato Grosso do Sul (Silva et al. 2007). No PRU, foi coletada em fitofisionomia de floresta estacional decidual e campo cerrado, entre 150 e $940 \mathrm{~m}$ de altitude.

15.4. Desmodium distortum (Aubl.) J.F. Macbr., Publ.

Field. Mus. Bot. Ser. 8(2): 101. 1930.

Subarbustos, ca. $15 \mathrm{~cm}$ alt. Ramos cilíndricos, estriados, ásperos ao tato, pubérulo-uncinados. Folhas 1-3-folioladas no mesmo indivíduo; pecíolo 2-4 mm compr.; estípulas 0,8-1,5 cm compr., amarelas, quase amplexicaules, oblíquas, acuminadas, estriadas, ciliadas, base alargada, auriculada; estipelas $5 \mathrm{~mm}$ compr., subuladas, estriadas, caducas; folíolos 8-15 × 6-11 cm, ovais a romboidais, ápice obtuso, face adaxial aderente, pálida, pubérulo-uncinada, com esparsos tricomas vilosos, face abaxial com tricomas retos, alvacentos a amarelados, vilosa ao tato, nervuras primárias e secundárias amareladas. Inflorescências em panículas, axilares e terminais; pedúnculo 9-18 cm compr.; brácteas subuladas, estriadas, pubescentes, caducas; cálice $1 \mathrm{~mm}$ compr., verde, 5-laciniado, lacínias do lábio superior soldadas até quase a metade; corola amarela; estandarte 6-7 mm compr., oboval; alas 5-6 mm compr., obovais; pétalas da quilha $5 \mathrm{~mm}$ compr., obovais; estames 10 , monadelfos; ovário pubérulo com microtricomas uncinados; estilete curvo, granuliforme; estigma terminal, glabro. Lomentos castanho-amarelados, curto-estipitados, retos a torulosos, 2-6-articulados; 
artículos $2 \mathrm{~mm}$ compr., ovais a elípticos, pubérulos, com tricomas uncinados, ístmo central; sementes reniformes, testa amarela a castanha.

Material examinado: BRASIL. MAto Grosso Do Sul: Corumbá, Serra Santa Cruz, Planalto Residual do Urucum, 10-IX-2004, fl., fr., Silva \& Silva 1124 (UEC).

No Brasil, ocorre nos estados de Amapá, PA, AM, MA, PI, CE, PB, PEW, BA, AL, MT, GO, DF, MS, MG, SP e RJ (Vanni 2001, Lima \& Oliveira 2010b). No PRU, foi coletada em formação de campo cerrado, a 887 m de altitude.

\subsection{Desmodium incanum DC., Prodr. 2: 232. 1825.}

Subarbustos, 15-40 cm alt. Ramos cilíndricos, ásperos ao tato, pubescentes a pubérulo-uncinados. Folhas 3-folioladas; pecíolo 0,5-4 cm compr.; estípulas 4-11 mm compr., ovais, marrons, estriadas, coalescentes, base truncada, ápice acuminado, face dorsal pubescente-uncinada, ciliada; estipelas 1-4 mm compr., setáceas; folíolos 2-5 × 0,5-2,4 cm, elípticos a lanceolados, base arredondada, ápice obtuso a agudo, face adaxial verde-escura, esparsopubescente a pubérula, face abaxial vilosa, acinzentada; Inflorescências racemosas, terminais ou subterminais, multifloras; pedúnculo 1,2-2,5 cm compr.; brácteas lanceoladas; bractéolas lanceoladas, dorso pubérulo; cálice $3 \mathrm{~mm}$ compr., verde-claro a roxo, laciniado, esparso-pubescente a pubérulouncinado, lacínias do lábio superior concrescidas até a metade, ciliadas; corola róseo-escura a lilás; estandarte 6-7 mm compr., oboval, ápice emarginado, base curtamente unguiculada; alas 5-6 mm compr., oblongas; pétalas da quilha 5,5-6 mm compr., oblongas, base curtamente unguiculada; estames 10 , diadelfos; ovário pubescente; estilete glabro; estigma terminal, glabro. Lomentos verde-acinzentados, curtoestipitados, 3-6-articulados suturas superiores retas, inferiores sinuosas, ístmo marginal; artículos 4-5 mm compr., transverso-oblongos a subqua-drangulares, hirsutos com tricomas uncinados; sementes reniformeassimétricas, testa amarela a castanha.

Material examinado: BRASIL. Mato Grosso Do Sul: Corumbá, Serra do Urucum, Planalto Residual do Urucum, 7-X-2003, fl., Silva \& Iziel 309 (UEC); Serra Santa Cruz, Planalto Residual do Urucum 17-XI-2003, fr., Silva \& Velásquez 565 (UEC); Serra Grande, Planalto Residual do Urucum, 17-I-2003, fl., fr., Silva \& Velásquez 131 (UEC). Ladário, Serra do
Rabichão, Planalto Residual do Urucum, 10-XII-2003, fl., fr., Silva \& Silva 638 (UEC).

No Brasil, ocorre nos estados de PA, AM, AC, MA, CE, PR, PE, BA, MT, GO, MS, MG, ES, RJ, PR, SC e RS (Azevedo 1981, Lima et al. 2010). No PRU, No PRU, foi encontrada em florestas estacionais deciduais e semideciduais e em cerradão, entre 150 e $700 \mathrm{~m}$ de altitude.

15.6. Desmodium tortuosum (Sw.) DC., Prodr. 2: 232. 1825

Arbustos 0,7-1,7 m alt. Ramos angulosos, sulcados a estriados, eretos, pubérulo-uncinados a estrigosos. Folhas 3-folioladas; pecíolo 2,2-4,5 cm compr.; estípulas 11-15 mm compr., esverdeadas, oblíquas, ovais a sub-retangulares, estriadas, base reta, ápice acuminado; estipela 1-4 mm compr., pardacenta a paleácea, subulada, estriada, base reta, ápice acuminado; folíolos 6-8,5 × 2,5-4 cm, verde-escuros, oblongo-ovais, pubescentes, base subarredondada a obtusa, ápice obtuso, apiculado, face adaxial canescente-estrigosa, face abaxial pubescente-uncinada. Inflorescências paniculadas, multifloras, terminais, estriadas, seríceo-hípidas; pedúnculo 3-9 cm compr.; bráctea oval-acuminada, estriada, pubérula, ciliada; bractéola oval, estriada, caduca; cálice 1-2,5 mm compr., verde com mancha roxa, bilabiado, lacínias lanceoladas, lacínias do lábio superior bífidas, as do lábio inferior trífidas; corola rósea; estandarte 4-5 mm compr., externamente verde, internamente róseo, oboval, glabro, base unguiculada; alas $4 \mathrm{~mm}$ compr., obovais, glabras, auriculadas, base unguiculada; pétalas da quilha $4 \mathrm{~mm}$ compr., obovais, base unguiculada; estames 10, diadelfos; ovário subséssil, estrigoso; estilete curvo, glabro; estigma terminal, glabro. Lomentos marrom-avermelhados, curto-estipitados a sésseis, tortuosos, 4-6-articulados; artículos 3-3,5 mm compr., orbiculares, reticulados, pubescente-uncinados, ístmo central, margem espessada; sementes orbicular-reniformes, testa castanha a amarela.

Material examinado: BRASIL. Mato Grosso do SuL: Corumbá, Serra do Urucum, Planalto Residual do Urucum, 31-I-2003, fl., fr., Silva \& Velásquez 234 (UEC); Serra Tromba dos Macacos, Planalto Residual do Urucum, 29-X-2003, fl., fr., Silva \& Velásquez 504 (UEC); Serra São Domingos, Planalto Residual do Urucum, 20-XI-2004, fr., Silva \& Velásquez 589 (UEC); Serra Santa Cruz, Planalto Residual do 
Urucum, 17-XII-2003, fl., Silva \& Silva 680 (UEC); Serra Grande, Planalto Residual do Urucum, 24-XI-2004, fr., Silva \& Velásquez 1308 (UEC).

No Brasil, ocorre nos estados de PB, PE, CE, BA, MS, MG, ES, SP, RJ, PR e RS (Azevedo 1981, Silva et al. 2007, Lima et al. 2010b). No PRU, foi coletada em áreas de floresta estacional decidual e campo cerrado, entre 394 e $511 \mathrm{~m}$ de altitude.

16. Dipteryx Screb., Gen. Pl. 2: 485. 1791.

\subsection{Dipteryx alata Vogel, Linnaea 11: 383. 1837.}

Árvores, 6-15 m alt. Ramos cilíndricos, lenticelados, glabros. Folhas pinadas, 8-10 folioladas; pecíolo 6,5-12 cm compr., alado; folíolos 5,3-9,2 × 3-4,7 cm, alternos a opostos, ovaloblongos, base oblíqua, truncado-arredondada a subcordada, ápice arredondado a obtuso, pelúcidopunctado em ambas as faces. Inflorescências em panículas, axilares, eixos tomentosos; pedúnculo 8-15 mm compr.; brácteas ovais; bractéolas obtusas, caducas; cálice 5,5-6 mm compr., verde, turbinadocampanulado, punctado, glabro, 5 lacínias,; corola alva, creme, róseo-clara a lilás; estandarte 7,5-8 mm compr., com mancha roxa a vermelha, reniforme, ápice emarginado, base curto-unguiculada; alas 6,4 mm compr., obliquamente oboval-oblongas, base unguiculada; pétalas da quilha $5 \mathrm{~mm}$ compr., com dorso quase livre; estames 10, monadelfos; ovário estipitado; estilete encurvado; estigma terminal. Drupas 5-5,5 cm compr., quando imaturas verdes com pontuações vermelhas conspícuas, quando maduras amarelas com pontuações escuras inconspícuas; sementes oblongas, testa castanho-escura.

Material examinado: BRASIL. Mato Grosso do Sul: Corumbá, Serra do Urucum, Planalto Residual do Urucum, 11-XI-1977, Lima et al. 156 (RB); 28-I-2003, Silva \& Velásquez 194 (UEC); 12-V-2004, fl., Silva \& Calisto 939 (UEC); 17-XII-2004, fl., fr., Silva \& Filho 1349 (UEC). Serra do Jacadigo, Planalto Residual do Urucum; 16-XII-2003, fl., fr., Silva \& Velásquez 660 (UEC); 27-XII-2004, fl., fr., Silva \& Velásquez 1373 (UEC); Serra São Domingos, Planalto Residual do Urucum, 13-I-2003, fl., fr., Silva \& Velásquez 116 (UEC); 20-II-2003, fl., Silva \& Velásquez 699 (UEC); 22-III-2004, fl., Silva \& Velásquez 793 (UEC); Serra Tromba dos Macacos, Planalto Residual do Urucum, 13-II-2003, fl., Silva \& Velásquez 261 (UEC); 28-IV-2003, fl.,
Silva \& Velásquez 907 (UEC); 21-XI-2003, fr., Silva \& Velásquez 596 (UEC); 19-XII-2003, fr., Silva \& Velásquez 693 (UEC); Serra Santa Cruz, Planalto Residual do Urucum, 10-II-2003, fl., Silva \& Velásquez 251 (UEC); 18-XI-2003, fr., Silva \& Silva 568 (UEC); 29-V-2004, fr., Silva \& Velásquez 922 (UEC); Serra Grande, Planalto Residual do Urucum, 24-III-2004, fl., Silva \& Velásquez 827 (UEC).

No Brasil, ocorre nos estados de TO, MA, PI, CE, BA, MT, GO, DF, MS, MG e SP (Lima 2010d). No PRU, foi encontrada em florestas estacionais deciduais e semideciduais, cerrado e cerradão, entre 281 e 729 m de altitude.

17. Eriosema (DC.) G. Don, Gen. Hist. 2: 347. 1832.

Chave para as espécies de Eriosema

1. Folhas 3-folioladas 17.1. E. crinitum 1. Folhas 1-folioladas 17.2. E. heterophyllum

17.1. Eriosema crinitum (Kunth) G. Don, Gen. Hist. Dichl. Plants 2: 348. 1832.

Subarbustos, 5-40 cm alt. Ramos delgados, caniculados, eretos a semi-prostrados, rufos a alvos, pubescentes a glabros. Folhas 3-folioladas; pecíolo 2-4 mm compr.; estípulas 5-16 mm compr., alvas a rufas, lanceoladas, coalescentes; folíolos 2,5-12 × 0,5-2 cm, linear-oblongos a lanceolados, base obtusa a subcordada, ápice agudo a obtuso, geralmente mucronado, ambas as faces pubescentes a glabras. Inflorescências pseudofasciculadas, 2-floras; brácteas lineares a lanceoladas, caducas; cálice 5-5,5 mm compr., verde, campanulado, 5-laciniado, externamente pubescente; corola amarela; estandarte 7-10 mm compr., oboval, externamente seríceo, ápice glanduloso, auriculado, base ungüiculada; alas 6,8-10 mm compr., unguiculadas, oblongas; pétalas da quilha 6,8-10 mm compr., falcadas, unguiculadas; estames 10, diadelfos; ovário séssil, viloso; estilete filiforme, curvo, glabro; estigma punctiforme. Legumes 1,5 cm compr., pretos, oblongo-ovais, externamente pubescentes; sementes ovais, testa preta a salpicada.

Chave para as variedades de E. crinitum

1. Planta rufo-pilosa; bráctea lanceolada;

legume rufo-piloso .................. 17.1.1. var. crinitum

1. Planta alvo-pilosa; bráctea linear;

legume alvo-piloso 17.1.2. var. pulchellum 


\subsubsection{Eriosema crinitum (Kunth) G.Don var. crinitum}

Material examinado: BRASIL. Mato Grosso do Sul: Corumbá, Serra do Jacadigo, Planalto Residual do Urucum, 13-II-2003, fl., fr., Silva \& Velásquez 265 (UEC); 25-X-2003, fl., Silva \& Velásquez 445 (UEC); 22-X-2004, fl., Silva \& Velásquez 1214 (UEC); 30-VII-2004, fl., fr., Silva \& Velásquez 1040 (UEC); Serra do Urucum, Planalto Residual do Urucum, 10-II-2003, Silva \& Maciel 260 (UEC); 3-X-2003, fl., Silva \& Iziel 289 (UEC); 13-VIII-2003, fl., Silva \& Velásquez 1071 (UEC); 27-X-2004, fl., Silva \& Iziel 1258 (UEC); Serra Santa Cruz, Planalto Residual do Urucum, 7-I-2003, fl., Silva \& Silva 100 (UEC); 27-VII-2004, fl., fr., Silva \& Silva 1001 (UEC); 9-IX-2004, fr., Silva \& Silva 1118 (UEC).

No Brasil, ocorre nos estados de RR, AP, PA, MA, CE, BA, MT, GO, MS, MG, SP e RJ (Fortunato 2010). No PRU, foi encontrada em fitofisionomia de campo cerrado, entre 761e $958 \mathrm{~m}$ de altitude.

\subsubsection{Eriosema crinitum var. pulchellum Benth.}

Material examinado: BRASIL. MAto GRosso do SuL: Corumbá, Serra Santa Cruz, Planalto Residual do Urucum, 10-II-2003, fl., fr., Silva \& Silva 254 (UEC).

No PRU, foi coletada em formação de floresta estacional semidecidual/campo cerrado, entre 500 e $958 \mathrm{~m}$ de altitude.

17.2. Eriosema heterophyllum Benth., Linnaea 23: 520. 1849.

Subarbustos xilopodíferos, $20-50 \mathrm{~cm}$ alt. Ramos cilíndricos, semi-eretos a semiprostrados, alvopubescentes. Folhas 1-folioladas; pecíolo 2-6 mm compr.; estípulas 4-10 mm compr., lanceoladas, coalescentes, persistentes; folíolos 1,8-7 × 0,7-4,2 cm, oval-lanceolados a subcordados, alvo-pubescentes a glabros em ambas as faces, base cordada a arredondada, ápice agudo a obtuso. Inflorescências racemosas, ultrapassando os folíolos; pedúnculo 2,2-15 cm compr.; brácteas lanceoladas, caducas; bractéolas ausentes; cálice 6-11 mm compr., verde, campanulado, externamente glanduloso; corola amarela; estandarte 12-14 mm compr., oboval, externamente glanduloso, auriculado; alas 10-13 mm compr., oblongas; pétalas da quilha 10-12 mm compr., oblongas; estames 10, diadelfos; ovário séssil, viloso; estilete curvo, glabro; estigma capitado. Legumes 1,5-2 cm compr., marrons a pretos, 2-valvados, oblongos; sementes oblongas, testa marrom a preta.

Material examinado: BRASIL. Mato Grosso Do Sul: Corumbá, Serra Santa Cruz, Planalto do Urucum, Mineração Corumbaense, 21-II-2005, fl., Pott \& Pott 12609 (HMS); 30-IX-2003, fl., Silva \& Velásquez 280 (UEC); Serra do Jacadigo, Planalto Residual do Urucum, 22-IX-2004, fl., Silva \& Velásquez 1215 (UEC); Serra Tromba dos Macacos, Planalto Residual do Urucum, 28-XI-2003, Silva \& Velásquez 484 (UEC); 26-X-2004, fl., Silva \& Velásquez 1239 (UEC); Serra São Domingos, Planalto Residual do Urucum, 30-XII-2004, fl., fr., Silva \& Velásquez 1383 (UEC).

No Brasil, ocorre nos estados de GO, DF, MS, MG, SP e PR (Grear 1970, Fortunato 2010). No PRU, foi coletada em fitofisionomia de campo cerrado, entre 673 e $950 \mathrm{~m}$ de altitude.

18. Erythrina L., Sp. P1. 2: 706. 1753.

18.1. Erythrina dominguezii Hass1., Physis. 6: 123. 1922.

Árvores caducifólias, 5-18 m alt. Ramos cilíndricos, aculeados, glabros. Folhas pinadas, 3-folioladas; pecíolo 1-1,8 cm compr. estípulas e estipelas não observadas, caducas; folíolo terminal 4-9 × 1,5-4,5 cm, oblongos, base subaguda, ápice obtuso, folíolos laterais assimétricos, face adaxial glabra, face abaxial densamente glandulosa, glândulas translúcidas, pretas a marrons. Inflorescências pseudoracemos, axilares, com 2-3-floras por pedúnculo; pedúculo $0,8-2 \mathrm{~cm}$ compr.; cálice 0,8-1,3 cm compr., verde-amarelado, truncado-giboso; corola com estandarte de $18 \mathrm{~mm}$ compr., salmão, oblongo, externamente salpicado de vermelho, ápice emarginado; alas $6 \mathrm{~mm}$ compr., deltóides, nervadas, glabras, auriculadas; pétalas da quilha $16 \mathrm{~mm}$ compr., vermelha, falcado-elípticas, coalescentes em toda a extensão do dorso, estriadas, externamente glabras, internamente papilosas, amplamente auriculadas; estames 10, monadelfos; ovário glabro. Folículos 5-6 cm compr., marrom-acastanhados, estipitados, lineares; sementes ovais, testa castanha.

Material examinado: BRASIL. Mato Grosso do Sul: Corumbá, Serra do Urucum, Planalto Residual do Urucum, 3-X-2003, Silva \& Calisto 291 (UEC); 28-X-2004, Silva \& Calisto 1264 (UEC); Serra Tromba dos Macacos, Planalto Residual do Urucum, 
Silva \& Velásquez 1165 (UEC); Serra Santa Cruz, Planalto Residual do Urucum, 22-IX-2004, fl., Silva \& Velásquez 1144 (UEC); 19-X-2004, fl., fr., Silva \& Velásquez 1182 (UEC).

No Brasil, ocorre nos estados de MT, GO, DF, MS e SP (Krukoff \& Barneby 1974, Lima 2010e). No PRU apresentou ocorrência restrita à floresta estacional decidual, entre 187 e $549 \mathrm{~m}$ de altitude.

19. Galactia P. Browne, Civ. Nat. Hist. Jamaic: 298. 1756.

Chave para as espécies de Galactia

1. Plantas herbáceas

2. Folíolos em número de 1 19.1. G. boavista

2. Folíolos em número de 3 ou 1-3 no mesmo indivíduo

3. Folhas subsésseis, subcoriáceas, digitadas, 1-3-folioladas 19.4. G. pretiosa

3. Folhas pecioladas, membranáceas,

pinadas, 3-folioladas 19.5. G. striata

1. Plantas subarbustivas a arbustivas

4. Face abaxial dos folíolos glauca; cálice interna e externamente seríceo 19.2. G. glaucescens

4. Face abaxial dos folíolos verdegrisácea; cálice externamente subviloso e internamente glabro 19.3. G. latisiliqua

19.1. Galactia boavista (Vell.) Burkart, Darwiniana 16(3-4): 783. 1971.

Ervas xilopodíferas, $10-30 \mathrm{~cm}$ alt. Ramos cilíndricos, eretos, suberetos a semiprostrados. Folhas 1-folioladas; pecíolo 2-4 mm compr.; estípulas 3-5 mm compr., lanceolado-subuladas, pubescentes; estipelas caducas; folíolos 4-10,8 × 1,2-4,8 cm, concolores, ovais, elípticos a oblanceolados, base cuneada, ápice subobtuso, obtuso a emarginado, face adaxial pubescente, face abaxial pubescente. Inflorescências em racemos, axilares; pedúnculo 3-12 cm compr.; cálice 7-10 mm compr., verde, campanulado, pubescente-seríceo; corola rosa a roxa; estandarte $12 \mathrm{~mm}$ compr., oboval, dorso glabro, ápice pubérulo; alas $11 \mathrm{~mm}$ compr., obovais, glabras no dorso, ciliadocaducas, base auriculada, unguiculada; pétalas da quilha $10 \mathrm{~mm}$ compr., oblongas, auriculadas, base unguiculada; estames 10, diadelfos; ovário séssil, curvo, hirsuto, estilete encurvado, glabro; estigma punctiforme. Legumes 4,4 cm compr., castanhos, lineares, sésseis a subsésseis, retos a ascendentes, tomentosos; sementes oblongas, testa castanha, mormoreada a preta.

Material examinado: BRASIL. Mato Grosso do Sul: Corumbá, Serra do Jacadigo, Planalto Residual do Urucum, 22-X-2004, fl., fr., Silva \& Velásquez 1217 (UEC); Serra Santa Cruz, Planalto Residual do Urucum, 30-IX-2003, fl., fr., Silva \& Silva 284 (UEC); 31-X-2003, fl., fr., Silva \& Silva 520 (UEC); 8-IX-2004, fl., fr., Silva \& Silva 1115 (UEC).

No Brasil, ocorre nos estados de MT, GO, SP, PR (Burkart 1971, Fortunato 2010). No PRU, apresentou ocorrência restrita ao campo cerrado, entre 700 e $1.065 \mathrm{~m}$ de altitude.

19.2. Galactia glaucescens Kunth, Nov. Gen. Sp. Pl. 6: 431.1823.

Arbustos, 30-80 cm alt. Ramos cilíndricos, glabros. Folhas pinadas, 3-folioladas; pecíolo 1-3 mm compr.; estípulas 1,5-3 mm compr., lanceoladas, caducas; estipelas 1,5-3 mm compr., setáceas; folíolos 3-11 × 1,5-5,5 cm, elípticos a ovóides, base arredondada a truncada, ápice subagudo, emarginado, mucronado, face adaxial lustrosa, face abaxial glauca, glabros em ambas as faces. Inflorescências em racemos, nodosas, seríceas; pedúnculo $7-20 \mathrm{~cm}$ compr.; cálice 4-7 mm compr., verde, interna e externamente seríceo; corola roxa; estandarte 11-12 mm compr., oboval, externamente verde com estrias vermelhas a vináceas, pubescente a glabrescente, internamente lilás com estrias verdes, base unguiculada, margem ciliada; alas 9-10 mm compr., ápice obtuso, ciliado, esculturada, auriculada, base unguiculada; pétalas da quilha 9-10 mm compr., ápice obtuso, base unguiculada; estames 10, diadelfos; ovário linear, séssil, seríceo; estilete encurvado, esparsamente piloso a glabro; estigma punctiforme. Legumes 4-6 cm compr., castanhos, lineares, marginados, seríceos, ápice levemente curvo; sementes oblongas, testa marrom-escura, com manchas e pintas pretas.

Material examinado: BRASIL. Mato Grosso do Sul: Corumbá, Serra do Jacadigo, Planalto Residual do Urucum, 22-X-2004, fl., fr., Silva \& Velásquez 1216 (UEC); 22-XI-2004, fr., Silva \& Velásquez 1287 (UEC); Serra Tromba dos Macacos, Planalto Residual do Urucum 13-II-2003, fl., fr., Silva \& Velásquez 270 (UEC); Serra Santa Cruz, Planalto Residual do Urucum, 31-X-2003, fl., fr., Silva \& Silva 524 (UEC); 10-IX-2004, fl., Silva \& Ramires 1121 (UEC). Ladário, Serra do Rabichão, Planalto Residual do Urucum, 22-X-2003, fl., fr., Silva \& Silva 396 (UEC). 
No Brasil, ocorre nos estados de PA, MA, CE, PE, BA, MT, GO, MS, MG e SP (Fortunato 2010a). No PRU, foi encontrada em fitofisionomia de floresta estacional decidual e campo cerrado, entre 617 e $848 \mathrm{~m}$ de altitude.

19.3. Galactia latisiliqua Desv. Ann. Sci. Nat. 9: 414. 1826. var. latisiliqua

Subarbustos, 30-40 cm alt. Ramos cilíndricos, volúveis, verde-grisáceos, subvilosos. Folhas pinadas, 3-folioladas; pecíolo 0,5-0,9 mm compr.; estípulas e estipelas não vistas, caducas; folíolos 1,1-5 × 0,7-3 cm compr., pinado-retinervados, discolores, elíptico-ovais, base obtusa a arredondada, ápice obtuso, mucronulado a emarginado, face adaxial verde-grisácea, faces subvilosas. Inflorescências em racemos, axilares, pedunculadas, 1-4-floras, subvilosas; pedúnculo 0,9-2,2 cm compr.; cálice $1,5 \mathrm{~cm}$ compr., verde, lacínias 4, triangulares, externamente subviloso; corola lilás; estandarte $24 \mathrm{~mm}$ compr., com pequenas aurículas não inflexas, base unguiculada; alas $20 \mathrm{~mm}$ compr., auriculadas, base unguiculada; pétalas da quilha $18 \mathrm{~mm}$ compr., obtusas, aurículas não inflexas, base unguiculada; estames 10, diadelfos, glabros; ovário curto-estipitado, densamente viloso; estilete encurvado, glabro; estigma punctiforme. Legumes 3-4 cm compr., acinzentados, ápice levemente curvo curtamente recurvo-rostrados, patentes, pubescente-velutínos, constrictos entre as sementes; sementes oblongas, testa castanha com manchas marrom-escuras a pretas.

Material examinado: BRASIL. MAto Grosso do SuL: Corumbá, Serra do Jacadigo, Planalto Residual do Urucum, 23-V-1989, fr., Pott et al. 4856 (CPAP); Serra Grande, Planalto Residual do Urucum, 17-I-2003, fr., Silva \& Velásquez 143 (UEC); 23-X-2003, fr., Silva \& Velásquez $406 B$ (UEC). Ladário, Serra do Rabichão, Planalto Residual do Urucum, 10-III-2003, fl., fr., Silva \& Silva 639 (UEC).

No Brasil, ocorre nos estados de MS, MG, RJ (Burkart, 1971, Silva 2006). No PRU, ocorre na floresta estacional decidual, entre 150 e $231 \mathrm{~m}$ de altitude.

19.4. Galactia pretiosa var. trifoliolata (Hassl.) Burk., Darwiniana 16(3-4): 753. 1971.

Ervas napiformes, 5-30 cm alt. Ramos eretos, glabrescentes. Folhas subsésseis, subcoriáceas, digitadas, 1-3-folioladas; pecíolo 2-7 mm compr.; estípulas lineares, glabras; estipela não observada; folíolos 4-10 ×6-7 cm, linear-lanceolados, pinadoretinervados, marginados, base cuneada, ápice agudo, faces glabras. Inflorescências axilares, 1-2-floras; botões florais ovais, pubescentes; pedúnculo $2-11 \mathrm{~cm}$ compr.; cálice $7 \mathrm{~mm}$ compr., verde, com lacínias vermelhas, agudas, externamente piloso e internamente esparso-piloso; corola róseo-escura a lilás; estandarte 11-21 mm compr., oboval, curtamente auriculado, ápice emarginado; alas 16-20 mm compr., obovais, glabras, auriculada, base unguiculada; pétalas da quilha 18-21 mm compr., oblongas, coalescentes em toda a extensão do dorso, auriculadas, base unguiculada; estames 10, diadelfos; ovário hirsuto, indumento ferrugíneo e esbranquiçado; estilete arqueado, piloso; estigma punctiforme. Legumes 3,5-4,5 cm compr., lineares, cinza-escuros a marrons, pubescentes; sementes ovóides, testa castanha com manchas pretas.

Material examinado: BRASIL. Mato Grosso do Sul: Corumbá, Serra Tromba dos Macacos, Planalto Residual do Urucum, 28-XI-2003, fl., fr., Silva \& Velásquez 495 (UEC); Serra Santa Cruz, Planalto Residual do Urucum, 7-II-2003, fl., fr., Silva \& Velásquez 237 (UEC); 30-IX-2003, fr., Silva \& Ramires 286 (UEC).

No Brasil, ocorre nos estados de MS e PR (Fortunato 2010a). No PRU, foi encontrada em campo cerrado, a $756 \mathrm{~m}$ de altitude.

19.5. Galactia striata (Jacq.) Urb. Symb. Antill. 2(2): 320. 1900 var. striata

Ervas, 0,5-1,3 m alt. Ramos cilíndricos, volúveis, tomentosos. Folhas pinadas, 3-folioladas, membranáceas; pecíolo 0,5-1,5 cm compr.; estípulas 2-3 mm compr., triangulares a subuladas, estriadas; estipelas $2 \mathrm{~mm}$ compr., subuladas; folíolos 2-4-5,5 × 10,9-2,9 cm, elípticos a oval-lanceolados, base cordada a subcordada, ápice obtuso a subagudo, mucronado, face adaxial verde-amarelada, pubescente na nervura principal, face abaxial pubescente. Inflorescências racemosas, axilares, tomentosas; 5-11-floras; pedúnculo 1-2 cm compr.; bractéolas lanceoladas, tomentosas, inseridas na base do cálice; cálice 1,2-1,5 cm compr., verde, lacínias 4, triangulares, externamente tomentosas, internamente pubescentes a glabrescentes; corola lilás; estandarte $25 \mathrm{~mm}$ compr., oboval, estriado, ápice retuso com tricomas esparsos a glabros; alas $20 \mathrm{~mm}$ compr., estriadas, esculturadas, auriculadas, base unguiculada; pétalas da quilha $18 \mathrm{~mm}$ compr., auriculadas, 
base unguiculada; estames 10, diadelfos; ovário densamente pubescente, estilete encurvado, glabro; estigma punctiforme. Legumes 4-5 cm compr., cinzaescuros, sésseis, lineares, patentes; sementes ovais, testa amarelo-clara, com manchas e pintas ferrugíneas e pretas.

Material examinado: BRASIL. MAto Grosso do SuL: Corumbá, Serra do Jacadigo, Planalto Residual do Urucum, 24-III-2004, fl., fr., Silva \& Velásquez 1058 (UEC); 30-IV-2004, fr., Silva \& Velásquez 927 (UEC); Serra Tromba dos Macacos, Planalto Residual do Urucum, 25-III-2004, fl., fr., Silva \& Velásquez 835 (UEC); Serra Grande, Planalto Residual do Urucum, 26-III-2004, fl., fr., Silva \& Velásquez 826 (UEC).

No Brasil, ocorre nos estados de PA, AM, PB, BA, MT, MS, MG, SP, RJ e PR (Fortunato 2010). No PRU, foi encontrada em florestas estacionais deciduais e semideciduais, entre 220 e $564 \mathrm{~m}$ de altitude.

20. Indigofera L. Sp. P1. 2: 751. 1753.

Chave para as espécies de Indigofera

1. Folhas 3-7-folioladas; estípulas subuladas, estipela nula

2. Cálice com lacínias de tamanhos semelhantes; corola rósea ........... 20.1. I. guaranitica

2. Cálice com lacínias de tamanhos desiguais; corola salmão ..... 20.2.I. lespedezioides

1. Folhas 11-19-folioladas; estípulas setáceas, estipela oval-acuminada .... 20.3. I. suffruticosa

20.1. Indigofera guaranitica Hassler, Repert. Spec. Nov. Regni Veg. 16: 160. 1919.

Arbustos, 30-70 cm alt. Ramos cilíndricos, eretos. Folhas 5-7-folioladas; pecíolo 0,8-1 cm compr.; estípulas $5 \mathrm{~mm}$ compr., subuladas, livres; estipela nula; folíolos 1,2-1,7 × 0,7-1,1 cm, oblongos a obovaloblongos, base e ápice obtusos, tricomas bifurcados adpressos em ambas as faces. Inflorescências em racemos, axilares, ultrapassando as folhas; bráctea 1 , subulada; pedúnculo 0,7-1,5 cm compr.; cálice 3-4 mm compr., verde, lacínias de tamanho semelhantes; corola rósea; estandarte $0,2-0,4 \mathrm{~mm}$ compr., orbicular, externamente com tricomas bifurcados, adpressos a eretos; alas $3 \mathrm{~mm}$ compr., glabras; pétalas da quilha 3-4 mm compr., com esparsos tricomas bifurcados, adpressos, às vezes glabrescentes; estames 10 , diadelfos; ovário curtamente estipitado, glabrescente; estilete arqueado; estigma capitado, glabro. Legumes 2,5-2,9 cm compr., marrons, levemente curvos, cilíndricos a compressos, tricomas bifurcados; sementes cubiformes, testa marrom.

Material examinado: BRASIL. Mato Grosso do Sul: Corumbá, Serra do Jacadigo, Planalto Residual do Urucum, 16-I-2003, fl., fr., Silva \& Velásquez 129 (UEC). Ladário, Serra do Rabichão, Planalto Residual do Urucum, 22-X-2003, fl., fr., Silva \& Silva 391 (UEC); 18-III-2004, fr., Silva \& Silva 770 (UEC).

No Brasil, ocorre nos estados de GO, DF, MS e MG (Rodas 1991). No PRU, ocorre na floresta estacional decidual, a $165 \mathrm{~m}$ de altitude.

20.2. Indigofera lespedezioides Kunth, Nov. Gen. Sp. P1. 6: 457. 1824.

Subarbustos xilopodíferos, ca. $30 \mathrm{~cm}$ alt. Ramos eretos, pubescentes, com tricomas bifurcados, adpressos, braços do mesmo tamanho. Folhas 3-7-folioladas; pecíolo 1-2 cm compr., caniculado; estípulas $6 \mathrm{~mm}$ compr., subulado-acuminadas, livres; estipela nula; folíolos 1,8-4,7 × 0,7-2,1 cm, opostos, lanceolado-obovais a oboval-oblongos, base cuneada, ápice obtuso, tricomas bifurcados adpressos e estrigosos em ambas as faces. Inflorescências em racemos axilares, mais curtos, iguais ou mais longos do que as folhas; pedúnculo 2-6 cm compr.; bráctea 1 , subulada; cálice $3 \mathrm{~mm}$ compr., verde, lacínias de tamanho desiguais; corola salmão; estandarte 3-4 mm compr., orbicular, cordiforme a oval, externamente com tricomas bifurcados adpressos; alas 2-4 mm compr., oblíquo-subovadas, glabrescentes; pétalas da quilha 2-4 mm compr., obtusas, com tricomas bifurcados no ápice e na nervura central; estames 10 , diadelfos; ovário curto-estipitado, com tricomas bifurcados adpressos; estilete arqueado, glabro; estigma capitado, glabro. Frutos não observados.

Material examinado: BRASIL. Mato GRosso do SuL: Corumbá, Serra Santa Cruz, Planalto Residual do Urucum, 30-IX-2003, fl., Silva \& Silva 279 (UEC).

Espécie de ampla distribuição, Caribe, América Central e América do Sul (ILDIS 2005). No Brasil, ocorre nos estados de RR, PA, AM, TO, RO, MA, BA, MT, GO, DF, MS, MG, SP e RS (Rodas 1991, Miotto \& Iganci 2010). No PRU, foi encontrada em área de campo cerrado, a $1.000 \mathrm{~m}$ de altitude.

20.3. Indigofera suffruticosa Miller, Mem. Dict.: 2. 1768.

Arbustos, 0,3-1,8 m alt. Ramos estriados, seríceos. 
Folhas 11-19-folioladas; pecíolo 1-1,7 cm compr.; estípulas 4-5 mm compr., setáceas; estipela 1-2 mm compr., oval-acuminada; folíolos 1,7-4,2 ×0,6-1,8 cm, opostos, oblongos a obovais, base aguda, ápice agudo a obtuso, face adaxial glabrescente, face abaxial com tricomas bifurcados adpressos. Inflorescências em racemos axilares; pedúnculo 4-5 cm compr.; cálice $1 \mathrm{~mm}$ compr, verde, campanulado, lacínias de tamanho desiguais; corola rósea; estandarte $4 \mathrm{~mm}$ compr., internamente verde com guias verdes a róseas, oblongo, oboval a orbicular, externamente com tricomas bifurcados, adpressos; alas $4 \mathrm{~mm}$ compr., glabras; pétalas da quilha $4 \mathrm{~mm}$ compr., externamente com esparsos tricomas bifurcados no ápice; estames 10, diadelfos; ovário com tricomas bifurcados ou glabros; estilete curvo, glabro; estigma terminal, ciliado. Legumes 1-1,3 cm compr., quando imaturos verdes com manchas vermelhas, maduros marrons, acentuadamente curvos, cilíndricos; sementes oblongas, testa olivácea.

Material examinado: BRASIL. Mato Grosso do Sul: Corumbá, Serra do Jacadigo, Planalto Residual do Urucum, 20-IX-2004, fr., Silva \& Velásquez 1132 (UEC); Serra Santa Cruz, Planalto Residual do Urucum, 9-I-2003, fr., Silva \& Silva 104 (UEC); 17-XII-2003, fl., fr., Silva \& Velásquez 671 (UEC); Serra Grande, Planalto Residual do Urucum, 23-X-2003, fl., Silva \& Velásquez 416 (UEC); 24-XI-2004, fl., Silva \& Velásquez 1306 (UEC). Ladário, Serra do Rabichão, Planalto Residual do Urucum, 16-X-2003, fl., Silva \& Silva 351 (UEC); 10-XII-2003, fl., fr., Silva \& Silva 631 (UEC).

No Brasil, ocorre nos estados de RR, AP, PA, AM, AC, MA, CE, RN, PB, PE, BA, AL, MT, GO, DF e MS (Rodas 1991, Miotto \& Iganci 2010). No PRU, foi encontrada em florestas estacionais deciduais e semideciduais e em mata de galeria, entre 159 e $707 \mathrm{~m}$ de altitude.

21. Lonchocarpus Kunth, Nov. Gen. Sp. P1. 6: 300. 1824.

Chave para as espécies de Lonchocarpus

1. Corola alvo-amarelada, cremeamarelada a amarela; margem vexilar na região das sementes formando 2 sub-alas 21.1. L. pluvialis

1. Corola lilás-purpúrea; margem vexilar sem a formação de sub-alas 21.2. L. variabilis
21.1. Lonchocarpus pluvialis Rusby, Mem. New York Bot. Gard. 7(3): 268. 1927.

Figura 5

Árvores, 12-20 m alt. Ramos cilíndricos, lenticelados, amarelados a dourado-ferrugíneos, pubérulos. Folhas 5-7-folioladas; pecíolo 1,1-2,1 cm compr.; estípulas caducas; folíolos 2,1-5,3 $\times 1,8-3,5 \mathrm{~cm}$, opostos a subopostos, oblongos a elípticos, base arredondada, ápice subobtuso, curto acuminado, face adaxial dos folíolos jovens dourada, tomentosa, face abaxial dourada, pubescente a pubérula, ambas as faces das folhas adultas glabras, às vezes na face adaxial, galhas em forma de concha. Inflorescências em pseudoracemos, axilares, densifloras, dourado-tomentosas; pedúnculo 3,7-5,2 cm compr.; brácteas caducas; bractéolas orbicular-ovais, persistentes, inseridas na base do cálice, seríceas; cálice 4-7 mm compr., na planta viva arroxeado, no material seco amarelo-dourado, campanulado, seríceo, lacínias desiguais, dentadas; corola alvo-amarelada, creme-amarelada a amarela; estandarte 7-12 mm compr., oboval, externamente com bolsas inconspícuas amarelas, pubescente, auriculado, base curtamente unguiculada, ápice emarginado; alas 8-10 mm compr., levemente falcadas, pubescentes em ambas as faces, auriculadas, base unguiculada; pétalas da quilha 7-10 mm compr., levemente falcadas, auriculadas, base unguiculada, pubescentes; estames 10, pseudomonadelfos; ovário seríceo, séssil; estilete curvado no lado vexilar; estigma punctiforme. Legumes 4,8-6 cm compr., castanhoamarelados, oblongos, coriáceos, ápice obtuso a agudo, estipitados, margem vexilar levemente sinuosa, na região das sementes formando 2 sub-alas, margem carenal compressa, curvos, coriáceos, pubérulos, ferrugíneo-amarelados; sementes oblíquo-oblongas, testa castanho-ferrugínea.

Material examinado: BRASIL. Mato Grosso do SuL: Corumbá, Serra do Jacadigo, Planalto Residual do Urucum, 16-VII-2003, Silva \& Velásquez 653 (UEC); 23-X-2004, fl., Silva \& Velásquez 1154 (UEC); Serra Tromba dos Macacos, Planalto Residual do Urucum, 25-XI-2004, fl., Silva \& Velásquez 1312 (UEC); Serra Santa Cruz, Planalto Residual do Urucum, 29-X-2003, fl., Silva \& Silva 511 (UEC); 17-XII-2003, fl., fr., Silva \& Velásquez 662 (UEC); 22-IX-2004, fr., Silva \& Velásquez 1145 (UEC); Serra Grande, Planalto Residual do Urucum, 24-III-2004, fl., fr., Silva \& Velásquez 830 (UEC). 


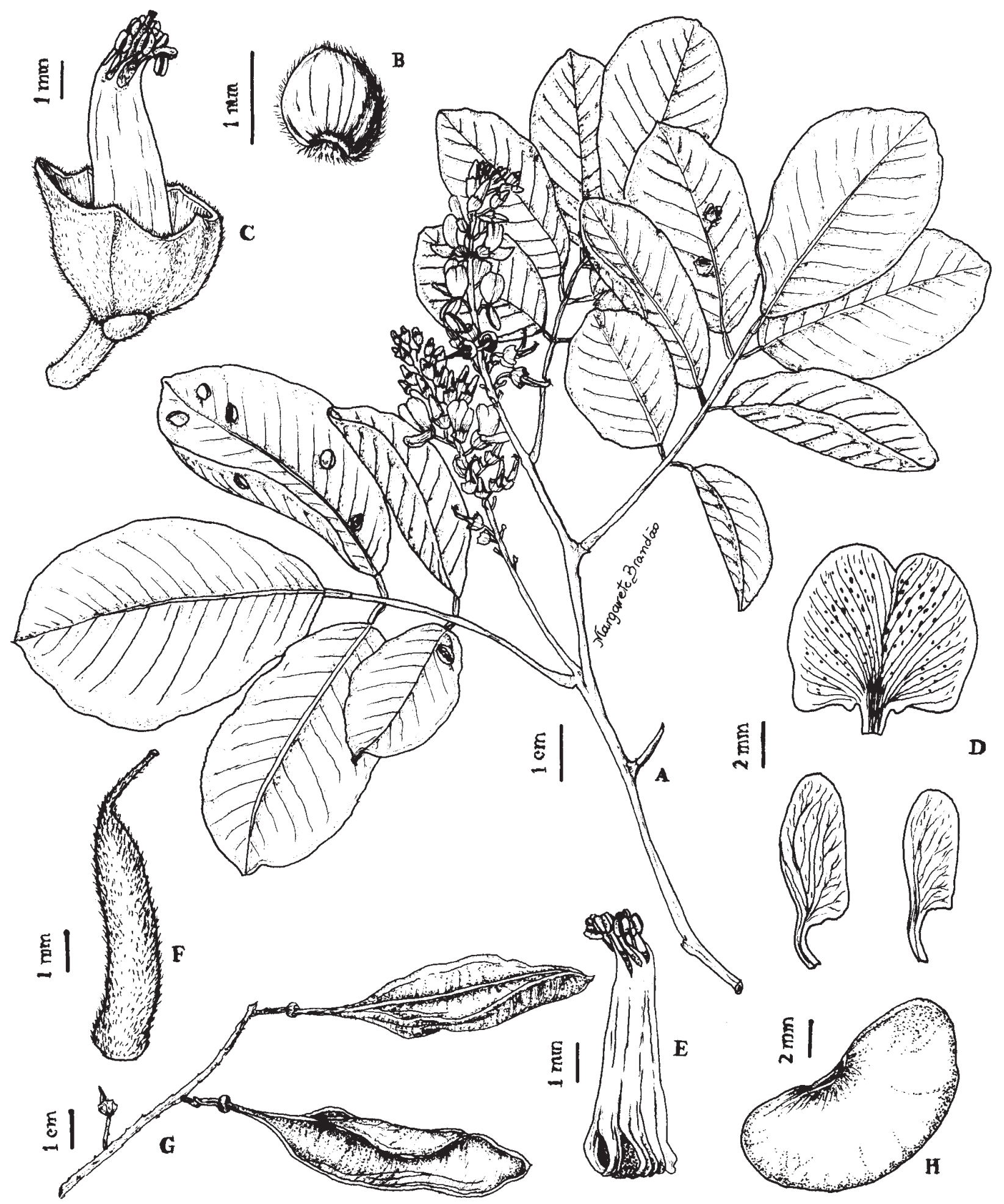

Figura 5. Lonchocarpus pluvialis. A. Ramo com inflorescência. B. Vista da face interna da bractéola. C. Cálice e androceu. D. Pétalas: vexilo(acima), asa (à esquerda), carena (à direita). E. Androceu. F. Gineceu. G. Frutos. H. Semente (R.R. Silva \& J.S. Velásquez 830, UEC).

Figura 5. Lonchocarpus pluvialis. A. Branch with inflorescence. B. Bracteole internal face view. C. Calyx and androecium. D. Petals: standard (above), wing (on the left), keel petals (on the right). E. Androecium. F. Gynoecium. G. Fruits. H. Seed (R.R. Silva \& J.S. Velásquez 830, UEC). 
No Brasil, ocorre no estado de MS (Silva 2006). No PRU, ocorre em formação de floresta estacional decidual, entre 106 e $424 \mathrm{~m}$ de altitude.

\section{2. * Lonchocarpus variabilis R.R. Silva \& A.M.G.}

Azevedo, Brittonia 60(1): 34. 2008.

Arbustos a árvores decíduas, 1,7-9 m alt. Ramos estriados, lenticelados, glabros. Folhas 5-folioladas, alternas; pecíolo 2-5 cm compr., delgado, subcilíndrico a subcaniculado, pubescente a glabro; estípulas $15 \mathrm{~mm}$ compr., ovais, estrigosas, ciliadas, caducas; folíolos terminais 3,4-8,6 × 1,6-4,9 cm, opostos a subopostos, raro alternos, oblongos a obovais, membranáceos quando jovens, subcoriáceos quando adultos, ápice acuminado, às vezes levemente retuso, base obtusa a arredondada, ambas as faces quando jovens prateadas, seríceas, adultas discolores, pubescentes a glabras, indumento ferrugíneo e amarelo, nervuras na face adaxial impresas e proeminentes na face abaxial. Inflorescências racemosas com flores geminadas axilares, eixos seríceos, pubescentes a glabros; brácteas e bractéolas 2, lanceoladas, pubescentes, caducas; pedúnculo 4,3-5,5 cm compr.; cálice 4-7 mm compr., vináceo na planta viva, campanulado, giboso a simétrico, 5-lobado, lacínias proeminentes, deltóides a triangulares, às vezes truncado na base, seríceo a pubescente, margem ciliolada; corola lilás-purpúrea; estandarte 6-12 mm compr., orbicular, oboval a oblíquooboval, unguiculado, externamente pubescente; alas 8-11 mm compr., elípticas, elíptico-oblongas a subfalcadas, aurículas curtas a ausentes, unguiculadas, esculturadas, pubescentes a glabrescentes; pétalas da quilha 7-9 mm compr., oblongas, unguiculadas, pubescentes principalmente no ápice, dorso coalescente; estames 10, pseudomonadelfos; ovário linear, curtamente estipitado, seríceo; estilete curvo a arqueado, glabro. Legumes 3,8-12,3 cm compr., ferrugíneos, amarelos a marrons, coriáceos, compressos, oblongo-elípticos a lanceolados, seríceos a glabrescentes, ápice acuminado, indumentos ferrugíneos e amarelos, margens espessadas; sementes amplo-reniformes, compressas, testa macia, marrom.

Material examinado: BRASIL. Mato Grosso Do Sul: Corumbá, Serra do Urucum, 29-XII-1993, fr., Edna e Juerlene s.n. (COR/3210); Serra Santa Cruz, Planalto Residual do Urucum, 9-XI-2004, fl., Silva \& Sebastião 1266 (CEN, HMS, UEC); Serra do Jacadigo, Planalto Residual do Urucum, 23-IX-1997, fl., Vaz \& Baracat 15 (COR); 26-V-2004, fl., Silva \&
Velásquez 962 (UEC); acesso pela fazenda Dois Corações, 21-X-2004, fl., Silva \& Velásquez 1190 (UEC); Serra São Domingos, 23-IX-2004, fl., Silva \& Velásquez 1159 (CGMS, HUEFS, UEC); 25-XI-2004, fl., Silva \& Velásquez 1316 (MBM, NY, UEC). Ladário, Serra do Rabichão, Planalto Residual do Urucum, 16-X-2003, fr., Silva \& Silva 329 (UEC); 26-V-2004, Silva \& Silva 743 (UEC); 28-II-2004, fr., Silva \& Silva 761 (UEC).

Restrita ao Brasil, no estado de MS (Silva \& Tozzi 2008). No PRU, foi coletada em floresta estacional decidual, entre 171 e $400 \mathrm{~m}$ de altitude.

22. Machaerium Pers., Syn. Pl. 2 (2): 276. 1807.

Chave para as espécies de Machaerium

1. Venação dos folíolos craspedódroma; ramos sem cicatrizes estipulares

2. Arbustos a árvores escandentes; estípulas espinescentes recurvadas, persistentes ........................... 22.1. M. aculeatum

2. Árvores; estípulas espinescentes

retilíneas, caducas .... 22.2. M. hirtum

1. Venação dos folíolos broquidódroma; ramos com cicatrizes estipulares ..... 22.3. M. villosum

22.1. Machaerium aculeatum Raddi, Mem. Mat. Fis. Soc. Ital. Sci. Moderna, Pt. Mem. Fis. 18(2): 398. 1820.

Figura 6

Arbustos a árvores escandentes, 2,5-12 m alt.; ramos armados, sem cicatrizes estipulares, pubérulos. Folhas 15-37-folioladas; pecíolo 1-1,5 cm compr.; estípulas $6 \mathrm{~mm}$ compr., espinescentes recurvadas, pareadas, rígidas, persistentes; folíolos 21-31 × 7-9 mm, alternos a opostos, membranáceos, oblongos, base oblíquo-obtusa, sedoso-pubescentes a glabrescentes em ambas as faces, ápice agudo a retuso; venação craspedódroma. Inflorescências em panículas, axilares e terminais; pedúnculo $5-15 \mathrm{~cm}$ compr.; bráctea triangular, rufo-tomentosa; bractéolas orbiculares, glabras; cálice 5,8-6 mm compr., lilás, campanulado, glabro, margem pubérula; corola com estandarte de $8 \mathrm{~mm}$ compr., lilás com mácula amarela e guias vináceas, suborbicular, pubescente, base unguiculada, ápice emarginado; alas 7,3-8,1 mm compr., lilases, oblongas, auriculadas, base unguiculada, nervura dorsal hirsuta; pétalas da quilha 7,3-8,1 mm compr., alvo-esverdeadas, falcadas, auriculadas, pubescentes

* O nome atualmente aceito para Lonchocarpus variabilis R.R. Silva \& A.M.G. Azevedo é Muellera variabilis (R.R. Silva \& A.M.G Azevedo) M.J.Silva \& A.M.G.Azevedo, proposto em Taxon 61(1): 104.2012. 


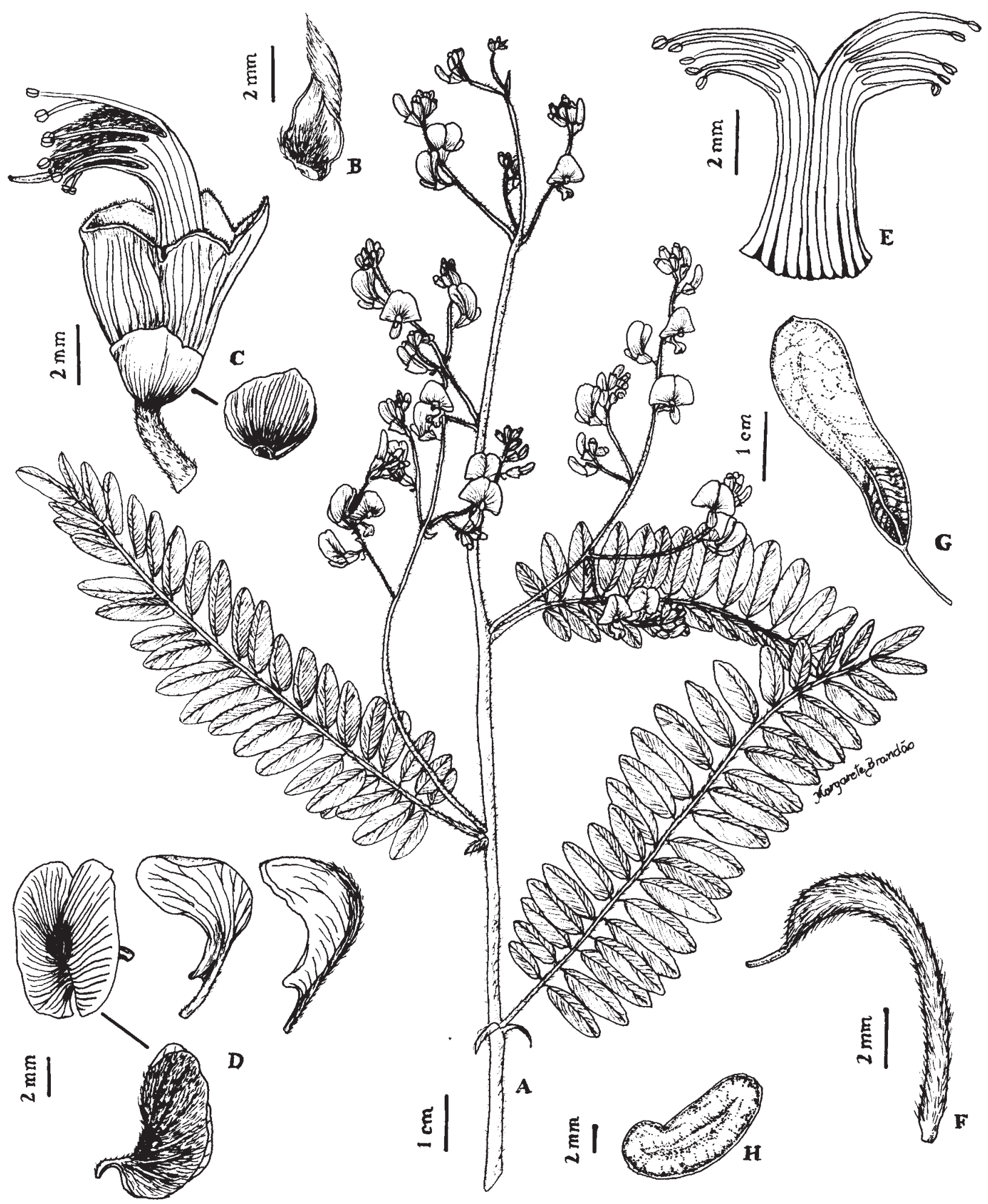

Figura 6. Machaerium aculeatum. A. Ramo com inflorescência. B. Bráctea. C. Cálice evidenciando o androceu e face interna da bractéola. D. Pétalas: vexilo, face interna (à esquerda), face externa (abaixo), asa, face interna (meio), carena, face interna (à direita). E. Androceu. F. Gineceu. G. Fruto. H. Semente (R.R. Silva \& J.S. Velásquez 1329, UEC).

Figura 6. Machaerium aculeatum. A. Branch with inflorescence. B. Bract. C. Calyx showing the androecium and e bracteole internal face. D. Petals: standard, internal face (on the lef), external face (below), wing, internal face (middle), keel petals, internal face (on the right).

E. Androecium. F. Gynoecium. G. Fruit. H. Seed (R.R. Silva \& J.S. Velásquez 1329, UEC). 
na metade inferior da margem, base unguiculada; estames 10 , monadelfos $(5 ; 5)$; ovário curtamente estipitado, encurvado, pubescente; estilete curvo; estigma capitado. Sâmaras cultrifomes, 4,5-5,5 cm compr., asas castanhas, região do núcleo seminífero marrom-escura; sementes fusiforme-oblongas, testa castanha.

Material examinado: BRASIL. Mato Grosso do Sul: Corumbá, Serra do Urucum, Planalto Residual do Urucum, 28-X-2003, fr., Silva \& Velásquez 263 (UEC); 27-XII-2004, fr., Silva \& Velásquez 1255 (UEC); Serra São Domingos, Planalto Residual do Urucum, 25-X-2004, fr., Silva \& Velásquez 1234 (UEC); Serra Santa Cruz, Planalto Residual do Urucum, 9-IX-2004, fl., Silva \& Silva 1120 (UEC); 26-XI-2004, fl., fr., Silva \& Silva 1329 (UEC).

No Brasil, ocorre nos estados de PE, BA, AL, GO, DF, MT, MS, MG, ES, SP e RJ (Lewis 1987, Bortoluzzi et al. 2004, Filardi 2010). No PRU, encontrada na floresta estacional decidual e semidecidual, cerradão e campo cerrado, entre 499 e 900 m de altitude.

\subsection{Machaerium hirtum (Vell.) Stellfeld, Tribuna}

Farm. 12: 132. 1944.

Árvores, 4,5-16 m alt. Ramos armados, sem cicatrizes estipulares, glabrescentes. Folhas 29-57-folioladas; pecíolo 3-5 cm compr.; estípulas 1,5 mm compr., espinescentes retilíneas, caducas; folíolos 12-16 × 2,9-4,9 mm, alternos a subopostos, cartáceos, estreito-oblongos, base oblíqua, ápice obtuso, retuso e mucronado, face adaxial glabrescente, face abaxial serícea; venação craspedódroma. Inflorescências em panículas, axilares e terminais; pedúnculo 9,7-16,1 cm compr.; bractéolas orbiculares; cálice 3,5-5,1 cm compr., verde-lilás, cilíndrico, lacínias desiguais, externamente tomentoso a glabrescente, ápice obtuso; corola lilás; estandarte 6,8-10,5 mm compr., com mácula amarela, oblongo, externamente seríceo, auriculada, base unguiculada; alas 7,5-11,5 mm compr., elípticas, seríceas no dorso, esculturadas, base auriculada; pétalas da quilha 7,1-9,7 mm compr., elípticas, com pequena cavidade na porção carenal; estames 10 , monadelfos; ovário curtamente estipitado, incano-velutíno, curvos; estilete curvo; estigma clavado. Sâmaras $5-7,5 \mathrm{~cm}$, marrons, oblongas, estipitadas, alas cremes a amarelas, oblongas, basais, esparsamente tomentosas, reticuladas na região seminífera; sementes fusiformeoblongas, testa marrom.
Material examinado: BRASIL. Mato Grosso Do Sul: Corumbá, Serra do Jacadigo, Planalto Residual do Urucum, 30-IV-2004, fr., Silva \& Velásquez 934 (UEC); Serra do Urucum, Planalto Residual do Urucum, 31-III-2004, fl., fr., Silva \& Silva 1066 (UEC); Serra Tromba dos Macacos, Planalto Residual do Urucum, 25-III-2003, fl., fr., Silva \& Velásquez 833 (UEC); 28-IV-2004, fr., Silva \& Velásquez 906 (UEC); Serra Santa Cruz, Planalto Residual do Urucum, 31-III-2004, fl., fr., Silva 861 \& Velásquez (UEC).

No Brasil, ocorre nos estados de PA, TO, AC, MA, PI, RN, PB, PE, BA, AL, GO, DF, MT, MS, MG, ES, SP e RJ (Lewis 1987, Bortoluzzi et al. 2004, Filardi 2010). No PRU, foi encontrada em florestas estacionais deciduais e semideciduais, cerrado e cerradão, entre 350 e $600 \mathrm{~m}$ de altitude.

49.3. Machaerium villosum Vogel, Linnaea 11: 189. 1837.

Figura 7

Árvores, 5-15 m alt. Ramos inermes, com cicatrizes estipulares. Folhas imparipinadas, 10-23-folioladas; pecíolo 2,1-4,1 cm compr., canescente-viloso a glabrescente; folíolos 5,5-7,8 $\times 1,5-2,7 \mathrm{~cm}$, membranáceos a levemente cartáceos, alternos a subopostos, lanceolados a obovais, base arredondada a atenuada, ápice agudo, face adaxial subvilosa, face abaxial sedosa ao tato, subvilosa a glabrescente; venação broquidódroma. Inflorescências em panículas com fascículos axilares; pedúnculo $12-14 \mathrm{~cm}$ compr., eixo canescente-viloso; flores sésseis; bráctea deltóide; bractéolas 2, ovais, tomentosas; cálice 2,9 mm compr., campanulado, rufo-tomentoso, lacínias desiguais; corola alva a alvo-esverdeada; estandarte 7,5 $\mathrm{mm}$ compr., externamente alvo-enegrescido, orbicular, tomentoso, base unguiculada, ápice retuso; alas elípticas, pubescentes, auriculadas, base unguiculada; pétalas da quilha 7,4 mm compr., elípticas, pubérulas, base auriculada, unguiculada; ovário curtamente estipitado, densamente viloso; estilete curto, subreto, glabro; estigma capitado. Sâmaras 6,5-6,8 mm compr., marrom-escuras, oblongas, alas castanhas, região seminífera rugosa; sementes irregularmente oblongas, marginadas, testa castanha.

Material examinado: BRASIL. Mato Grosso do SuL: Corumbá, Br-262, entre morro São Domingos e Lagoa Jacadigo, 30-IX-1996, fl., Pott 7880 (CPAP); Serra do Jacadigo, Planalto Residual do Urucum, 30-IV-2004, fr., Silva \& Velásquez 928 (UEC); Serra do Urucum, Planalto Residual do Urucum, 27-XI-2003, fr., Silva \& Velásquez 617 (UEC); 9-X-2003, fl., fr., Silva \& 


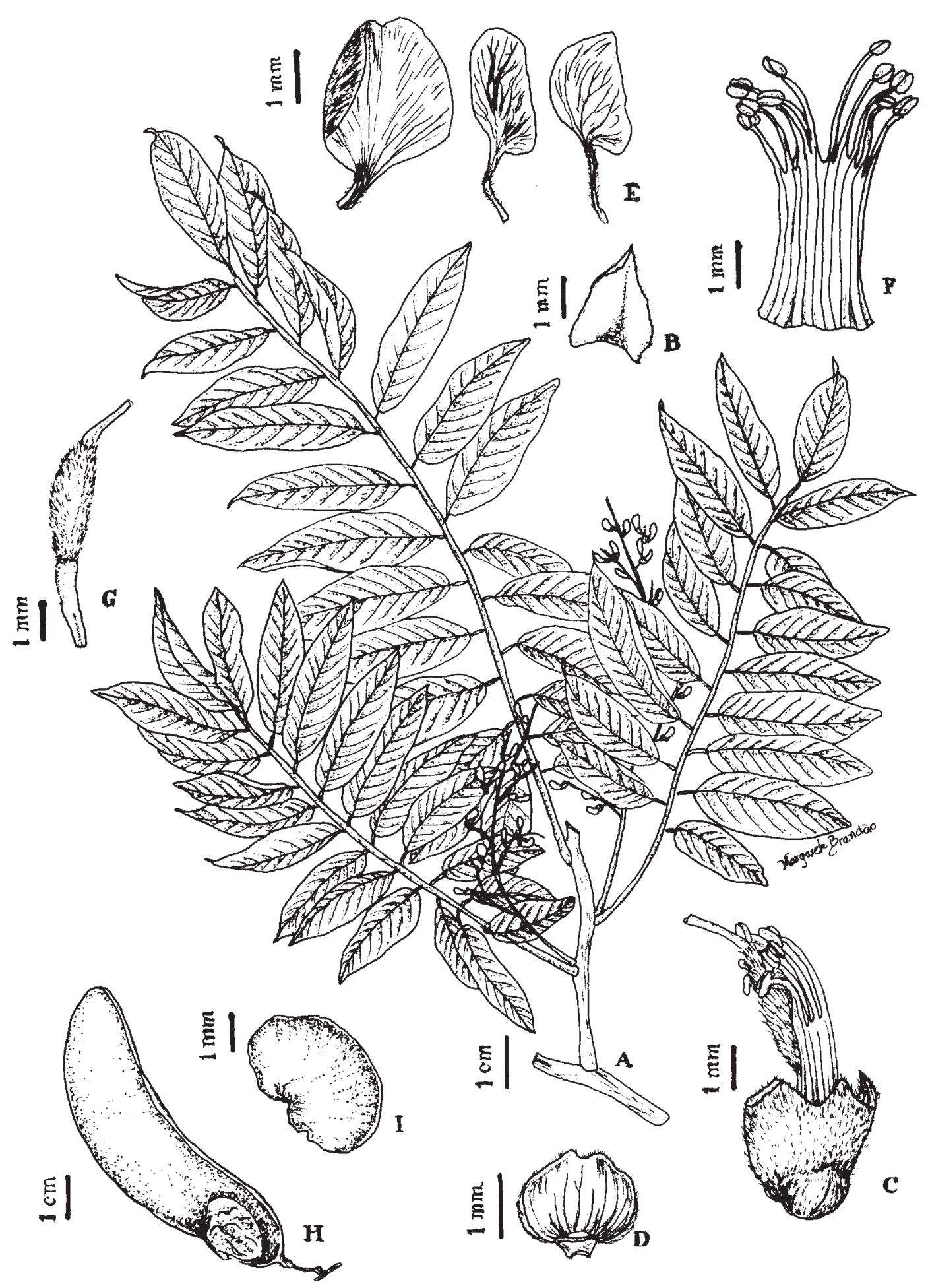

Figura 7. Machaerium villosum. A. Ramo com inflorescência. B. Bráctea. C. Cálice evidenciando parcialmente o androceu e o gineceu. D. Bractéola. E. Pétalas: vexilo (à esquerda), asa (meio), carena (à direita). F. Androceu. G. Gineceu. H. Fruto. I. Semente (R.R. Silva \& J.S. Velásquez 1018, UEC).

Figure 7. Machaerium villosum. A. Branch with inflorescence. B. Bract. C. Calyx showing androecium e gynoecium partly. D. Bracteole. E. Petals: standard (on the left), wing(middle), keel petals (on the right). F. Androecium. G. Gynoecium. H. Fruit. I. Seed (R.R. Silva \& J.S. Velásquez 1018, UEC). 
Velásquez 315 (UEC); 12-VIII-2004, fr., Silva \& Vaz Filho 1067 (UEC); 27-X-2004, fl., fr., Silva \& Velásquez 1253 (UEC); Serra Tromba dos Macacos, Planalto Residual do Urucum, 30-VII-2004, fr., Silva \& Velásquez 1032 (UEC); Serra São Domingos, Planalto Residual do Urucum, 20-XI-2003, fr., Silva \& Velásquez 578 (UEC); 23-IX-2004, fl., Silva \& Velásquez 1155 (UEC); 22-X-2004, fl., fr., Silva \& Velásquez 1221 (UEC); 22-XII-2004, fl., Silva \& Silva 1368 (UEC); Serra Santa Cruz, Planalto Residual do Urucum, 11-XI-2003, fr., Silva \& Silva 535 (UEC); 19-II-2004, fr., Silva \& Silva 728 (UEC); Serra Grande, Planalto Residual do Urucum, 28-VII-2004, fr., Silva \& Velásquez 1018 (UEC).

No Brasil, ocorre nos estados de PI, BA, DF, MS, MG, SP, PR e SC (Filardi 2010). No PRU, foi encontrada em florestas estacionais deciduais e semideciduais e cerradão, entre 230 e 726 m de altitude.

23. Macroptilium (Benth.) Urb., Symb. Antill. 9 (4): 457. 1928.

23.1. Macroptilium bracteatum (Nees \& Mart.) Maréchal \& Baudet, Bull. Jard. Bot. Belg. 44(3-4): 443. 1974.

Arbustos trepadores, ca. $1 \mathrm{~m}$ alt. Ramos volúveis, estriados. Folhas 3-folioladas; pecíolo 1,3 cm compr.; estípulas 5-8 mm compr., deltóides, estriadas, seríceas; estipelas 2, 3-5 mm compr., lanceoladas, seríceas, caducas; folíolos oblíquos, lobados, os terminais $2,7-7 \times 2,2-5,7 \mathrm{~cm}$, sésseis, os laterais $2-7 \times 2-5 \mathrm{~cm}$, subsésseis, seríceos em ambas as faces, base obtusa a truncada, ápice arredondado, mucronado, margem inteira, ciliada. Inflorescências em racemos, axilares e terminais; pedúnculo 11,5-20 cm compr., sulcados, nodosos, seríceos; brácteas lanceoladas, agrupadas em fascículos, seríceas; cálice 5-6 mm compr., verde, seríceo; estandarte 13-17 mm compr., verderosado, oboval, base unguiculada, apendiculada, apêndices pouco conspícuos na base da lâmina, ápice emarginado, glabro; alas 22-29 mm compr., roxas, oblongas, auriculadas, base longamente unguiculada, glabra; pétalas da quilha 20-22 mm compr., róseas, sigmóides, lateralmente torcidas, auriculadas, base longamente unguiculada, glabra; ovário seríceo; estilete achatado, encurvado, glabro. Frutos não observados.

Material examinado: BRASIL. MAto Grosso do SuL: Corumbá, Serra do Urucum, Planalto Residual do Urucum, 31-I-2003, fl., Silva \& Maciel 235 (UEC).
No Brasil, ocorre nos estados de PI, CE, PB, PE, BA, MS, MG, SP e RJ (Moreira 1997). No PRU, encontrada em fitofisionomia de floresta estacional semidecidual, a $494 \mathrm{~m}$ de altitude.

24. Phaseolus L., Sp. Pl. 2: 723-725. 1753.

\subsection{Phaseolus lunatus L., Sp. Pl. 2: 724. 1753.}

Trepadeiras. Ramos volúveis. Folhas pinadas, membranáceas, 3-folioladas; pecíolo 5,2 cm compr., subviloso a glabrescente; estípulas e estipelas 1,8 $\mathrm{mm}$ compr., lanceolado-subuladas, estriadas, glabras, persistentes; folíolos terminais 4,9-12,5 × 2,7-8,5 cm, oval-rômbicos, base simétrica, arredondada, ápice arredondado, folíolos laterais 4,5-11,5 × 3,1-8,1 cm, face adaxial glabrescente, face abaxial pubescente, margem ciliada. Flores não observadas. Legumes 5,2-6,4 cm compr., marrons, valvas amplamente falcadas, lunadas; sementes orbiculares, testa preta.

Material examinado: BRASIL. Mato Grosso do Sul: Corumbá, Serra São Domingos, Planalto Residual do Urucum, 23-IX-1989, fr., Pott et al. 1001 (CPAP). Ladário, Serra Santa Cruz, Planalto Residual do Urucum, Rancho do Sr. Buguinho, fazenda São Marcelo,16-X-2000, fr., Damasceno Jr. \& Gonçalves 1968 (COR).

No Brasil, ocorre nos estados de MS, MG, SP, RJ e PR (Moreira 1997). No PRU, ocorre em fitofisionomia de floresta estacional semidecidual e floresta estacional semidecidual/cerradão.

25. Platypodium Vogel, Linnaea 11: 420. 1837.

25.1. Platypodium elegans Vogel, Linnaea 11: 420. 1837.

Árvores, 5-20 m alt. Ramos cilíndricos, caniculados, pubérulos. Folhas alternas, imparipinadas; pecíolo 1,3-2,2 cm compr.; estípulas $3 \mathrm{~mm}$ compr., deltóides, tomentosas; folíolos 10-21 × 3,2-4,8 cm, 13-17, subsésseis, subopostos, oboval-oblongos, glabros em ambas as faces, base obtusa a cuneada, ápice emarginado, mucronado; nervação eucamptódroma. Inflorescências em racemos, axilares terminais; pedúnculo 8-18 mm compr.; brácteas lanceoladas, tomentosas, caducas; cálice $8-10 \mathrm{~mm}$ compr., verde, turbinado-campanulado, margem pubescente; estandarte $14 \mathrm{~mm}$ compr., com guias vermelhas, oboval-orbicular, glabro, ápice emarginado, base unguiculada; alas 15-16 mm compr., oblongas, 
glabras, base unguiculada; pétalas da quilha 11-12 mm compr., obovais, glabras, dorso concrescido, base unguiculada; estames 10, diadelfos; ovário longoestipitado, lateralmente ciliado; estilete curvo, glabro; estigma inconspícuo, terminal. Sâmaras $6-8 \mathrm{~cm}$ compr., estipitadas, castanho-claras, glabras, região seminífera apical; sementes oblongo-reniformes, testa rugosa, marrom.

Material examinado: BRASIL. MATo GRosso do SuL: Corumbá, próximo ao areeiro do Chaim, em frente ao Morro São Domingos, 16-II-1995, fr., Pott et al. 2490 (CPAP); Serra do Jacadigo, Planalto Residual do Urucum, 21-X-2004, fl., fr., Silva \& Velásquez 1188 (UEC); Serra São Domingos, Planalto Residual do Urucum, 24-X-2003, fl., fr., Silva \& Velásquez 433 (UEC); 20-XII-2003, fl., fr., Silva \& Velásquez 700 (UEC); 26-IV-2004, Silva \& Velásquez 891 (UEC); 25-X-2004, fl., fr., Silva \& Velásquez 1229 (UEC); Serra Santa Cruz, Planalto Residual do Urucum, 29-X-2003, fl., fr., Silva \& Velásquez 517 (UEC); 28-V-2004, fr., Silva \& Velásquez 966 (UEC); Serra Grande, Planalto Residual do Urucum, 28-VII-2004, fr., Silva \& Velásquez 1025 (UEC).

No Brasil, ocorre nos estados de RR, PA, AM, TO, AC, RR, MA, PI, CE, BA, MT, GO, DF, MS, MG, ES, SP, RJ e PR (Lima 2010f), ocupando particularmente áreas de cerrado (Mendonça et al. 1998). No PRU, encontrada nas áreas de florestas estacionais deciduais e semideciduais, e de cerrado, entre 147 e $448 \mathrm{~m}$ de altitude.

26. Rhynchosia Lour., Fl. Cochinch.: 425. 1790.

Chave para as espécies de Rhynchosia

1. Cálice com 5 lacínias; legume oblíquo

2. Folíolos obliquamente romboidais, face abaxial com glândulas pretas ... 26.1. R. edulis

2. Folíolos ovais, face abaxial com glândulas amarelas 26.2. R. melanocarpa

1. Cálice com 4 lacínias; legume falcado 26.3. R. minima

26.1. Rhynchosia edulis Griseb., Abh. Konigl. Ges. Gattingen 19: 123. 1874.

Trepadeiras. Ramos volúveis, densamente vilosos, indumento amarelo. Folhas pinadas, 3-folioladas; pecíolo 0,9-3,5 cm compr.; estípulas 2,5-4,5 mm compr., lanceoladas; folíolos 1,4-5,4 × 1,2-3,5 cm, obliquamente romboidais, base truncado-subcordada, ápice agudo, mucronado, face adaxial densamente pilosa, face abaxial pilosa, glandulosa, glândulas pretas. Inflorescências em racemos axilares, 7-20-floras; pedúnculo 6-11 cm compr.; brácteas tomentosas, caducas; cálice 4-6 mm compr., verde, campanulado, glanduloso, glândulas pretas, 5 lacínias desiguais; estandarte 6,9-7,4 mm compr., amarelo com guias vináceas, oboval, auriculado, unguiculado, externamente pubescente; alas 5,7-6,3 mm compr., com a base creme e a parte distal vinácea, elípticas, uniauriculadas, glabras; pétalas da quilha 6-7 $\mathrm{mm}$ compr., cremes, obtusas, encurvadas, glabras; estames 10, diadelfos, glabros; ovário curtamente estipitado, viloso; estilete encurvado; estigma capitado. Legumes 1,9-2,2 cm compr., marrons, compressos, oblíquos; sementes compresso-globosas, testa marrom-amarelada com manchas pretas.

Material examinado: BRASIL. Mato Grosso do Sul: Corumbá, Serra Grande, Planalto Residual do Urucum, 21-XII-2004, fl., fr., Silva \& Velásquez 1307 (UEC). Ladário, Serra do Rabichão, Planalto Residual do Urucum, 10-XII-2003, fl., fr., Silva \& Velásquez 641 (UEC); 29-II-2004, fl., fr., Silva \& Velásquez 749 (UEC).

No Brasil, ocorre nos estados de CE, GO, MS, MG, SP, PR, SC e RS (Fortunato 2010b). No PRU, apresentou ocorrência na floresta estacional decidual, entre 216 e $392 \mathrm{~m}$ de altitude.

26.2. Rhynchosia melanocarpa Grear, Mem. New York Bot. Gard. 31(1): 43. 1978.

Trepadeiras. Ramos volúveis, tomentosos. Folhas pinadas, 3-folioladas; pecíolo 1,5-3,5 cm compr.; estípulas $2,5 \mathrm{~mm}$ compr., lanceoladas, tomentosas; folíolos 2,8-8,5 × 1,8-7,5 cm, ovais, base arredondada a subarredondada, ápice deltóide a obtuso, face adaxial e face abaxial densamente pilosas, dotada clavada de glândulas amarelas; nervuras proeminentes em ambas as faces. Inflorescências em racemos, 20-40-floras; pedúnculo $8 \mathrm{~cm}$ compr., piloso, glanduloso; cálice 4,7-5,5 mm compr., campanulado, densamente piloso, glanduloso, 5-laciniado, lacínias desiguais; corola amarela; estandarte 7-7,5 mm compr., oboval, tomentoso, glanduloso, auriculado, ápice emarginado, base unguiculada; alas 5,8-6,4 mm compr., estreitooblongas, aderidas às petalas da carena, uniauriculadas, unguiculadas, glabras; pétalas da quilha 6,4-7,2 mm compr., obovais, unguiculadas, pilosas, esparsamente glandulosas; estames 10, diadelfos; ovário curtamente estipitado, densamente tomentoso, estilete delgado 
da base até o meio e alargado do meio em direção ao ápice, piloso na base; estigma capitado. Legumes 1,5-2,3 cm compr., marrom-vináceos a marromescuros, oblíquos, curtamente estipitados, tomentosos, glandulosos; sementes globosas, testa marrom-escura a preta.

Material examinado: BRASIL. Mato Grosso do Sul: Ladário, Serra do Rabichão, Planalto Residual do Urucum, 29-IX-2004, fl., fr., Silva \& Silva 1167 (UEC).

No Brasil, ocorre nos estados de PA, AM, MA, CE, DF, MT, MS, MG, SP, RS e PR (Fortunato 2010b). No PRU, ocorre em fitofisionomia de floresta estacional decidual, a $304 \mathrm{~m}$ de altitude.

26.3. Rhynchosia minima (L.) DC., Prodr. Syst. Nat. Regni Veg. 2: 385.1825.

Trepadeiras. Ramos volúveis, pubescentes a glabrescentes. Folhas pinadas, 3-folioladas; pecíolo 1,2-3,5 cm compr.; estípulas $2 \mathrm{~mm}$ compr., setáceas, pilosas; folíolos 1-3,8 × 1-3,7 cm, rômbicos, base subcordada, ápice deltóide, faces pilosas, glandulosas, glândulas amarelas com centro preto. Inflorescências em racemos axilares, 10-22-floras; pedúnculo 3-18 cm compr.; brácteas caducas; cálice 3-4 mm compr., campanulado, verde, 4-lacíniado, lacínias estreitolanceoladas, acuminadas, pubescentes; corola amarela; estandarte 4,5-6,4 mm compr., oboval, externamente piloso, glanduloso, biauriculado, base unguiculada, ápice emarginado; alas estreito-oblongas, 4,5-5,2 mm compr., uniauriculadas, unguiculadas, oblongas, coalescentes na metade do dorso, esparsamente glandulosas; pétalas da quilha 4,2-5,9 mm compr., curvas, obtusas, unguiculadas, glabras; estames 10 , diadelfos; ovário curtamente estipitado, viloso; estilete encurvado. Legumes 1,5-1,7 cm compr., marromacetinados, falcados, densamente vilosos, com glândulas amarelas; sementes orbiculares, testa preta.

Material examinado: BRASIL. Mato Grosso do Sul: Corumbá, Serra do Jacadigo, Planalto Residual do Urucum, 25-X-2003, fl., fr., Silva \& Velásquez 459 (UEC); Serra Grande, Planalto Residual do Urucum, 27-IV-2004, fl., fr., Silva \& Velásquez 903 (UEC).
No Brasil, ocorre nos estados de PA, AM, CE, PB, BA, GO, MT, MS, MG, ES, RJ e PR (Fortunato 2010b). No PRU, coletada em fitofisionomia de floresta estacional decidual, entre 200 e 269 m de altitude.

27. Sesbania Scopoli, Introd.: 308. 1777.

27.1. Sesbania virgata (Cav.) Pers., Syn. Pl. 2(2): 316. 1807.

Arbustos, 0,8-2 $\mathrm{m}$ alt. Ramos cilíndricos, pubescentes a glabros. Folhas imparipinadas, alternas, 10-20 pares de folíolos; pecíolo 1,5-2,5 mm compr.; estípulas 3-4 mm compr., lanceoladas, caducas; folíolos 15-30 ×5-7 mm, alternos, oblongos a elípticoovais, base subarredondada, ápice arredondado a subarredondado, face adaxial punctada, glabra, face abaxial pilosa. Inflorescências em racemos; pedúnculo 6-8 cm compr.; brácteas linear-lanceoladas, caducas; bractéolas linear-lanceoladas, caducas; cálice 4-4,5 mm compr., petalóide, campanulado, 5-lobado, lobos desiguais, pubescente, margem ciliada; corola amarela; estandarte $12 \mathrm{~mm}$ compr., orbicular, glabro, base cordada, com um par de apêndices agudos sobre o unguículo, fortemente reflexa, ápice emarginado; alas $10 \mathrm{~mm}$ compr., oblongas, esculturadas, glabras; pétalas da quilha $12 \mathrm{~mm}$ compr., encurvadas, glabras; estames 10, pseudomonadelfos; ovário longoestipitado, obliquamente arqueado, glabro; estilete linear; estigma inconspícuo, clavado. Legumes 4,5-7,5 cm, marrons, indeiscentes, cilíndricos, torulosos, estipitados, rostrados, glabros, 4-alados, com as margens curto-expandidas, simulando alas; sementes reniforme-oblongas, testa marrom.

Material examinado: BRASIL. Mato Grosso do Sul: Corumbá, Serra do Jacadigo, Planalto Residual do Urucum 8-II-2003, fl., fr., Silva \& Velásquez 244 (UEC). Serra Grande, Planalto Residual do Urucum, 24-XI-2004, fl., Silva \& Velásquez 1305 (UEC).

No Brasil, ocorre nos estados de PE, BA, GO, DF, MT, MS, MG, ES, SP, RJ, PR, SC e RS (Iganci \& Miotto 2010). No PRU, encontrada somente na floresta estacional decidual, entre 150 e $393 \mathrm{~m}$ de altitude.

28. Stylosanthes Sw. Prodr. Veg. Ind. Occ.: 108. 1788.

\section{Chave para as espécies de Stylosanthes}

1. Flor e fruto sustentados por eixo rudimentar plumoso

2. Ramos com indumento estrigoso; estípula interna hialina, glabra 28.6. S. scabra

2. Ramos com indumento tomentoso, setoso; estípula interna paleácea, pubescente a vilosa 3. Lomento com 1 artículo, estilete residual longo e uncinado 
3. Lomento com 2 artículos, estilete residual curto e levemente recurvado 28.3. S. capitata

1. Flor e fruto sem eixo rudimentar plumoso.

4. Folha caduca; bráctea externa 1-foliolada, ovóide 28.4. S. gracilis

4. Folha persistente; bráctea externa 3-foliolada, elíptica

5. Folíolos com 3-7 pares de nervuras; bractéolas 2 . 28.5. S. guianensis

5. Folíolos com 11-13 pares de nervuras; bractéolas 3 28.1. S. acuminata

28.1. Stylosanthes acuminata M.B. Ferreira \& Sousa Costa, Brasil Anais 28 Congr. Nac. Bot.: 80.1977.

Subarbustos, 15-40 cm alt. Ramos eretos, vilosos a tomentosos. Folhas persistentes, pubescentes em ambas as faces; pecíolo 5-6 mm compr.; estípula externa 6-10 mm compr., elíptica, verde, 13-15 nervuras, pilosa, ápice acuminado, margem ciliada; estípula interna 5-8 $\mathrm{mm}$ compr., oblonga, verde, glabra; folíolos 16-30 × 2,5-7 mm, lanceolados, base obtusa, ápice agudo a obtuso, ambas as faces pilosas, com 5-11 pares de nervuras. Inflorescências em espigas ovais, congestas, 1-5 espigas, terminais; pedúnculo 7-24 $\mathrm{mm}$ compr.; bráctea externa 3-foliolada, elíptica, ápice bífido; bráctea interna ovóide; bractéolas hialinas, subpaleáceas, de ápice ciliado; eixo rudimentar plumoso ausente; cálice 12-13 mm compr., verde; corola amarela; estandarte 4-6 mm compr., oboval, estriado; alas 3-5 mm compr., oblongas; pétalas da quilha 3-4 mm compr., oblongas, glabras; estames 10, monadelfos; ovário oblongo, glabro; estilete achatado, glabro; estigma cristado. Lomento 1-articulado, castanho; artículo 2,5-3,5 mm compr., oboval-oblongo, reticulado, estilete residual ausente; sementes oblongas, testa castanha.

Material examinado: BRASIL. Mato Grosso do Sul: Corumbá, Serra São Domingos, Planalto Residual do Urucum, 22-III-2004, fl., fr., Silva \& Velásquez 1247 (UEC); Serra Santa Cruz, Planalto Residual do Urucum, 15-VII-2004, fl., fr., Silva \& Silva 1343 (UEC).

No Brasil, ocorre nos estados de GO, DF, MT, MS, MG e SP (Ferreira \& Costa 1979, Costa 2006, Costa \& Valls 2010). No PRU, foi coletada na formação de campo cerrado e cerradão, entre 449 e $700 \mathrm{~m}$ de altitude.

28.2. Stylosanthes bracteata Vogel, Linnaea 12: 70. 1838 .

Ervas, $10-15 \mathrm{~cm}$ alt. Ramos eretos, tomentosos, setosos. Folhas persistentes; pecíolo 1-3,5 mm compr.; estípula externa $5 \mathrm{~mm}$ compr., verde, elípticooboval a oboval, 13-15 nervuras, tomentosa; estípula interna $6 \mathrm{~mm}$ compr., paleácea, pubescente; folíolos 7-20 × 2-5 mm, lanceolados a obovais, base obtusa, ápice agudo a obtuso, ambas as faces pilosas, com 5-11 pares de nervuras; pecíolo 1-3 mm compr., tomentoso. Inflorescências em espigas capitadas, terminais, 1-2 espigas; pedúnculo $14 \mathrm{~mm}$ compr., bráctea externa ovóide, 1-foliolada, 15-17 nervuras, pilosas, ciliadas; bráctea interna ovóide; bractéola externa 1, interna 2, ciliadas; eixos rudimentares plumosos; cálice $13 \mathrm{~mm}$ compr., verde, lacínias de ápice ciliado; corola amarela; estandarte 5-6 mm compr., oboval; alas 2,8-3,8 mm compr., falcadas; pétalas da quilha 2,5-3,5 mm compr., falcadas, base auriculada; estames 10, monadelfos; ovário oblongo, glabro; estilete curvo, glabro; estigma cristado. Lomento 1-articulado, amarelo; artículo 3-5 mm compr., reticulado, densamente piloso, estiletes residuais encurvados; sementes oblongas, testa amarela a marrom.

Material examinado: BRASIL. MAto Grosso do Sul: Corumbá, Serra Santa Cruz, Planalto Residual do Urucum, 13-I-2003, fl., fr., Silva \& Silva 711 (UEC); 31-X-2003, fl., fr., Silva \& Silva 518 (UEC).

Ocorre na América do Sul, estando restrita ao Brasil (Ferreira \& Costa 1979). No Brasil, ocorre nos estados de GO, DF, MS, MG, SP e PR (Costa et al. 2008, Costa 2006). No PRU, coletada em área de campo cerrado, a $1.000 \mathrm{~m}$ de altitude.

28.3. Stylosanthes capitata Vogel, Linnaea 12: 70. 1838.

Ervas, $20 \mathrm{~cm}$ alt. Ramos eretos a prostrados, tomentosos, setosos. Folhas persistentes; pecíolo 2-5 mm compr.; estípula externa $6 \mathrm{~mm}$ compr., verde, ovóide, 6 nervuras; estípula interna 4-8 mm compr., paleácea, com dentes subulados, 3 nervuras, vilosa; folíolos 9-20 × 3-6 mm, oblongos a elípticos, vilosas, base obtusa, ápice agudo e mucronulado, com nervuras proeminentes em ambas as faces. Inflorescências em espigas capitadas, 2-4 espigas; pedúnculo 3-8 mm compr., não ultrapassando o comprimento dos frutos; bráctea externa 3-foliolada, 9-11 nervuras, sem cerdas, ápice ciliado; bráctea interna ovóide; bractéola 
externa 1, ovóide, interna 2, lanceoladas, ciliadas; cálice 4-6 mm compr., verde, com lacínias agudas, ápice ciliado; corola amarela; estandarte 5-6 mm compr., oboval; alas 3-4 mm compr., obovais, base auriculada; pétalas da quilha 3-4 mm compr., falcadas, base auriculada; estames 10, monadelfos; ovário oblongo, glabro; estilete curvo, pubescente; estigma cristado. Lomentos 2-articulados, castanhos; artículos 3-7 mm compr., o superior reticulado-nervado, glabro, o inferior esparso-pubescente a glabro, estilete residual levemente uncinado; sementes oblongas, testa amarela a preta.

Material examinado: BRASIL. MAto GRosso do SuL: Ladário, Serra do Rabichão, Planalto Residual do Urucum, 28-II-2004, fl., fr., Silva \& Silva 754 (UEC).

No Brasil, ocorre nos estados de RR, PA, MA, PI, CE, RN, PB, PE, BA, SE, GO, DF, MT, MS, MG e SP (Costa 2006, Costa \& Valls 2010). No PRU, encontrada em fitofisionomia de floresta estacional decidual, a $239 \mathrm{~m}$ de altitude.

28.4. Stylosanthes gracilis Kunth, Nov. Gen. Sp. Pl. 6: 507.1823 [1824].

Subarbustos, ca. $80 \mathrm{~cm}$ alt. Ramos cilíndricos, vilosos. Folhas caducas, pubescentes; pecíolo 2-3 mm compr.; estípula externa $5 \mathrm{~mm}$ compr., verde, oblongo-oval, 7-9 nervuras, piloso-cerdosas; estípula interna $6 \mathrm{~mm}$ compr., oblongas a ovais, hialinas; folíolos 10-18 × 1,5-4 mm, lanceolados a elípticos, base cuneada, ápice agudo, acuminado, face adaxial glabra, face abaxial pubescente. Inflorescências em espigas capitadas, congestas, terminais, 1-3 espigas; pedúnculo 10-20 mm compr.; bráctea externa $5 \mathrm{~mm}$ compr.,1-foliolada, elíptica, 7-9 nervuras, pubescentecerdosas; eixos rudimentares ausentes; bráctea interna ovóide; bractéolas 2, lineares; cálice 5-6 mm compr., verde, glabro; corola amarela; estandarte 6-7 $\mathrm{mm}$ compr., suborbicular, estriado em ambas as faces; alas 3-4 mm compr., falcado-oblongas; pétalas da quilha 2,5-4 mm compr., falcado-oblongas, base auriculada; ovário longo-estipitado, glabro; estilete curvo; estigma cristado. Lomento 1-articulado, castanho; artículo 2,5-3 mm compr., elíptico, reticulado; semente 1 reniforme, testa preta.

Material examinado: BRASIL. Mato Grosso do Sul: Corumbá, Serra Santa Cruz, Planalto Residual do Urucum, 10-I-2003, fl., fr., Silva \& Silva 113 (UEC).

No Brasil, ocorre nos estados de AP, PA, MA, CE, BA, GO, DF, MT, MS, MG, ES, SP, RJ e PR (Mohlenbrock 1957, Ferreira \& Costa 1979 ,
Costa 2006, Costa \& Valls 2010). No PRU, foi coletada em formação de campo cerrado, a $980 \mathrm{~m}$ de altitude.

28.5. Stylosanthes guianensis (Aubl.) Sw., Kongl. Vetensk. Acad. Nya Handl. 11: 296. 1789

Subarbustos, 0,2-1 m alt. Ramos cilíndricos, tomentosos, setosos. Folhas persistentes; pecíolo 2-8 mm compr.; estípula externa 4-14 mm compr., 10-22 nervuras, dentes subulados a triangulares, pubescentes; estípula interna 4-10 mm compr., ovóide, 3-7 nervuras; folíolos 1-3 × 0,3-0,9 cm, sésseis a subsésseis, elípticos a lanceolados, pilosas em ambas as faces, base obtusa, ápice agudo a obtuso. Inflorescências em espigas, ovais a globosas, 2-4 espigas; pedúnculo 5-20 mm compr.; bráctea externa quase sempre 3-foliolada, elíptica, 5-9 nervuras, pubescentes a cerdosas; bráctea interna elíptica; eixos rudimentares ausentes; cálice 4-8 mm compr., verde, pubescente; corola amarela; estandarte 4-7 mm compr., orbicular a suborbicular, com guias vináceas, estriado; alas 3-6 mm compr., base auriculada, esporão próximo à base; pétalas da quilha 2,5-3 mm compr., falcadas, concrescidas no dorso, base unguiculada; estames 10, monadelfos; ovário oblongo, glabro; estilete curvo, curto. Lomento 1-articulado, castanho-claro; artículo $3 \mathrm{~mm}$ compr., pubescente a glabro, estilete residual diminuto, curvo; sementes elípticas, testa amarela a marrom.

Material examinado: BRASIL. Mato Grosso Do Sul: Corumbá, Serra Tromba dos Macacos, Planalto Residual do Urucum, 25-III-2004, fl., fr., Silva \& Velásquez 405 (UEC); Serra São Domingos, Planalto Residual do Urucum, 22-III-2004, fl., fr., Silva \& Velásquez 801 (UEC); 26-XI-2004, fl., fr., Silva \& Calisto 165 (UEC); Serra Santa Cruz, Planalto Residual do Urucum, 10-XI-2003, fl., fr., Silva \& Silva 534 (UEC); 17-II-2004, fl., Silva \& Velásquez 712 (UEC). Ladário, Serra do Rabichão, Planalto Residual do Urucum, 22-X-2003, fl., Silva \& Silva 405 (UEC).

No Brasil, ocorre nos estados de MA, PI, CE, PB, BA, MT, GO, DF, MS, MG, ES, SP, RJ e PR (Costa 2006, Costa \& Valls 2010). No PRU, coletada em floresta estacional semidecidual, cerrado e campo cerrado, entre 600 e $1.000 \mathrm{~m}$ de altitude.

28.6. Stylosanthes scabra Vogel, Linnaea 12: 69. 1838.

Subarbustos, ca. $70 \mathrm{~cm}$ alt. Ramos cilíndricos, estrigosos. Folhas persistentes; pecíolo 2-5 mm compr., 
caniculado, viloso-glanduloso; estípula externa $4 \mathrm{~mm}$ compr., verde, oboval, com dentes triangulares, pilosocerdosa, 9-11 nervuras; estípula interna $5 \mathrm{~mm}$ compr., hialina, ovóide, glabra; folíolos 0,5-0,8 × 1,1-2,1 cm, subsésseis, elípticos a lanceolados, base cuneada, ápice arredondado a obtuso, face adaxial vilosa, face abaxial vilosa, estrigosa, 4-6 pares de nervuras; Inflorescências em espigas axilares e terminais, 1-2 espigas; pedúnculo 10-25 mm compr.; bráctea externa elíptica, 1-foliolada, ápice bidenteado, piloso-cerdosa; bráctea interna elíptica, 3-5 nervuras; bráctéola externa 1 , internas 2 , ápice ciliado; eixo rudimentar plumoso; cálice $6 \mathrm{~mm}$ compr., verde, glabro; corola amarela; estandarte 4-5 mm compr., mostarda com guias ferrugíneas, orbicular, glabro, ápice emarginado, base unguiculada; alas 3-3,5 mm compr., obovais, base longo-unguiculada, glabras; pétalas da quilha 2,5-3 mm compr., falcadas, base longo-unguiculada, glabra; estames 10, monadelfos; ovário glabro; estilete encurvado, glabro. Lomentos 2-articulados, castanhos; artículos 2-3 mm compr., glabrescentes, estilete residual levemente encurvado; sementes elípticas, testa amarela.

Material examinado: BRASIL. Mato Grosso do Sul: Corumbá, Serra Santa Cruz, Planalto Residual do Urucum, 31-X-2003, fl., fr., Silva \& Silva 523 (UEC).

No Brasil, ocorre nos estados de RR, PA, MA, PI, CE, RGN, PB, BA, AL, GO DF, MT, MS, MG, ES, SP e RJ (Sousa-Costa 2006, Costa \& Valls 2010). No PRU, ocorre em área de campo cerrado, a $980 \mathrm{~m}$ de altitude.

29. Sweetia Spreng., Syst. Veg. 2: 171, 213. 1825.

29.1. Sweetia fruticosa Spreng., Linn. Syst. Veg. ed. 16, 2: 213. 1825.

Figura 8

Árvores inermes, 10-18 m alt. Ramos cilíndricos, estriados, lenticelados, glabros. Folhas paripinadas, alternas; pecíolo 1,2-2 cm compr.; estípulas e estipelas não observadas, caducas; folíolos 1-3,5 × 0,6-1,8 cm, alternos a subopostos, 10-15, oblongos, alternos, base oblíqua, ápice emarginado, nervura central pubérula. Inflorescências em panículas, terminais; pedúnculo 5,5-7 cm compr.; brácteas e bractéolas não observadas, caducas; cálice 1,7 mm compr., verde, 5 lacínias, turbinado-campanulado, pubescente; corola com pétalas alvas, não auriculadas, glabras; estandarte 2,5-4 mm compr., lâmina oblata, base unguiculada, demais 4 pétalas subiguais, 3,7-4 $\mathrm{mm}$ compr., obovadas, base unguiculada; estames 10 , levemente coalescentes na base; ovário séssil a curtamente estipitado, cano-seríceo; estilete seríceo; estigma capitado. Legumes samaróides 3,5-5 cm, com 1 semente; semente oblonga, testa castanho-escura.

Material examinado: BRASIL. Mato Grosso do Sul: Corumbá, Serra Tromba dos Macacos, Planalto Residual do Urucum, 24-IX-2004, fr., Silva \& Velásquez 1160 (UEC); Serra Santa Cruz, Planalto Residual do Urucum, 29-X-2003, fr., Silva \& Velásquez 501 (UEC).

Material adicional examinado: BRASIL. São PAULO: Campinas, Cati, 27-IX-2001, fl., Rodrigues et al. 1202 (UEC).

No Brasil, ocorre nos estados de BA, GO, MS, MG, ES, SP, RJ, PR e SC (Mohlenbrock 1963, Lewis 1987, Rodrigues 2009, Cardoso 2010). No PRU, ocorreu na floresta estacional decidual, entre 177 e $321 \mathrm{~m}$ de altitude.

30. Vigna Savi, Nov. Giorn. Lett. 8: 113. 1824.

Chave para as espécies de Vigna

1. Plantas trepadeiras a herbáceas; inflorescências sem nodosidades glandulares

2. Cálice tubuloso; androceu com estame vexilar basalmente sigmóide. 30.1. V. caracalla

2. Cálice campanulado; androceu com estame vexilar basalmente giboso 30.3. V. linearis

1. Plantas arbustivas; inflorescências com nodosidades glandulares 30.2. V.firmula

30.1. *Vigna caracalla (L.) Verdc., Kew Bull. 24: 552. 1970.

Trepadeiras. Ramos volúveis. Folhas 3-folioladas; pecíolo 5-7 cm compr.; estípulas ovais; folíolos não lobados, os basais 7-13 × 4,5-9,6 cm, amplo-ovais, os terminais 7,1-12,4 × 4,4-7,9 cm, rômbicos, base obtusa, ápice agudo, faces glabras. Inflorescências em pseudoracemos, axilares; pedúnculo 4,5-15 cm compr.; cálice roxo, tubuloso, externamente glabro; corola creme-arroxeada; estandarte $33 \mathrm{~mm}$ compr., oblíquo, externamente pubescente, 2 apêndices transversais basais, base unguiculada, ápice retuso, margem ondulada; alas $22 \mathrm{~mm}$ compr., obtusas, auriculadas, base unguiculada; pétalas da quilha 13-16 mm compr., espiraladas, base unguiculada,

* O nome atual de Vigna caracalla (L.) Verdc. é Cochliasanthus caracalla (L.) Trew, proposto em Amer. J. Bot. 98(10): 1704. 2011).. 


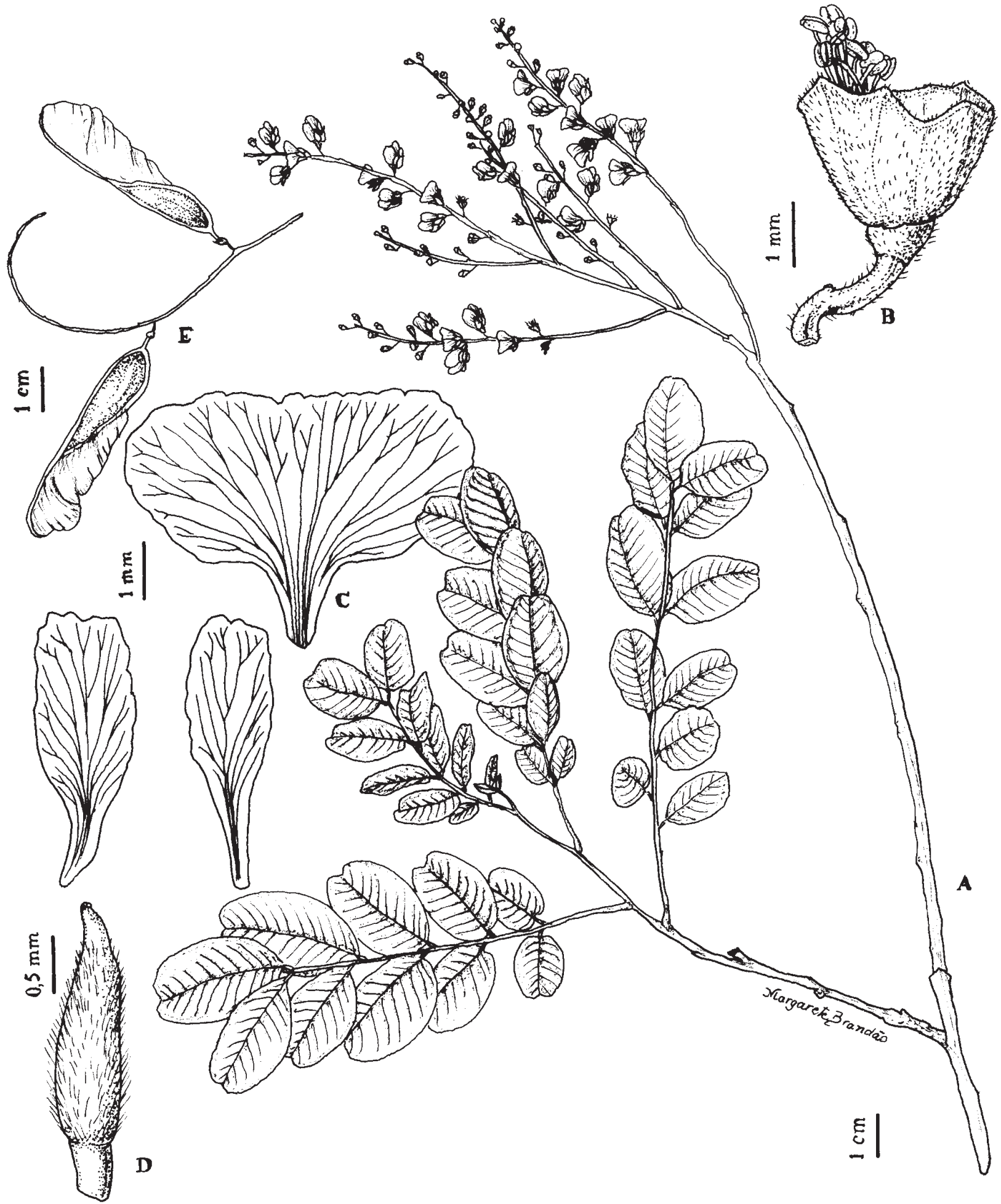

Figura 8. Sweetia fruticosa. A. Ramo com inflorescência. B. Cálice evidenciando filetes e anteras. C. Pétalas: vexilo (acima), asa (à esquerda, carena (à direita). D. Gineceu. E. Frutos (A-D: R.S. Rodrigues et al. 1202, UEC); F: R.R. Silva \& J.S. Velásquez 501, UEC).

Figura 8. Sweetia fruticosa. A. Branch with inflorescence. B. Calyx showing filaments and anthers. C. Petals: standard (above), wing (on the left), keel petals (on the right). D. Gynoecium. E. Fruits (A-D: R.S. Rodrigues et al. 1202, UEC); F: R.R. Silva \& J.S. Velásquez 501, UEC). 
apêndice unilateralmente oblíquo; estame vexilar basalmente sigmóide; ovário glabro; estilete sulcado; estigma terminal, angular. Legumes $13 \mathrm{~cm}$ compr., retos, lateralmente compressos, rostrados, suturas sinuosas nos frutos jovens; sementes não observadas.

Material examinado: BRASIL. Mato Grosso do Sul: Ladário, Serra Santa Cruz, Planalto Residual do Urucum, rancho do Sr. Buguinho, 6-IV-2001, fl., fr., Damasceno Jr. \& Velásquez 2279 (COR).

No Brasil, ocorre nos estados de PA, AC, PE, BA, GO, DF, MS, MG, ES, SP, RJ, PR, SC e RS (Moreira 1997, Perez 2010). No PRU, encontrada em fitofisionomia de floresta estacional decidual, a $300 \mathrm{~m}$ de altitude.

30.2. Vigna firmula (Mart. ex Benth.) Maréchal, Marscherpa \& Stainier, Taxon 27(2-3): 201. 1978.

Subarbustos, ca. $50 \mathrm{~cm}$ alt. Ramos cilíndricos, eretos. Folhas coriáceas, 3-folioladas; pecíolo 0,3-2,5 cm compr.; estípulas 2,5-3,9 mm compr., ovais, aderidas às estrias do caule, glabras; estipelas presentes; folíolos não lobados, os basais 4,4-9,5 × 2,5-6,1 cm, oblíquos, os terminais elípticos a ovais, base subcordada, ápice emarginado a obtuso, mucronulado, face adaxial glabra, face abaxial pubescente. Inflorescências em pseudoracemos, axilares, com nodosidades glandulares; pedúnculo 3,5-21,9 cm; cálice $7 \mathrm{~mm}$ compr., campanulado, verde, o carenal triangular, externamente esparsopubescente; corola amarela; vexilo $15 \mathrm{~mm}$ compr., orbicular, com 2 apêndices transversais basais, base curtamente unguiculada, ápice emarginado; alas $14 \mathrm{~mm}$, falcado-obovais, esculturadas, auriculadas, glabras, base unguiculada; pétalas da quilha $12,5 \mathrm{~mm}$ compr., lateralmente torcidas, coalescentes, apêndice oblíquo bilateral, base unguiculada; androceu com tubo estaminal auriculado, estame vexilar basalmente giboso; ovário pubescente; estilete com a porção basal delgada; estigma angular, torcido, pubescente. Frutos não observados.

Material examinado: BRASIL. MATo Grosso do SuL: Corumbá, Serra Santa Cruz, Planalto Residual do Urucum, 20-IX-2004, fl., Silva \& Silva 1114 (UEC).

No Brasil, ocorre nos estados de PA, TO, MA, PI, BA, GO, DF, MT, MS, MG e SP (Moreira 1997, Perez 2010). No PRU, ocorre em formação de campo cerrado, a $881 \mathrm{~m}$ de altitude.

30.3. * Vigna linearis (Kunth) Maréchal, Marscherpa \& Stainier, Taxon 27(2-3): 202. 1978.
Trepadeiras a ervas, 40-60 cm alt. Ramos volúveis. Folhas 3-folioladas; pecíolo 1,5-4,9 cm compr.; estípulas 3,2-4,5 cm compr., ovais a lanceoladas; folíolos levemente lobados a não lobados, os basais 2,8-6,1 $\times 0,9-3,5 \mathrm{~cm}$, oblíquos, os terminais 3,5-7,2 $\times 0,7-4,9 \mathrm{~cm}$, ovais a lanceolados, base obtusa a retusa, ápice agudo a obtuso, esparso-pubescentes a glabros em ambas as faces; Inflorescências em pseudoracemos, axilares; cálice 6-6,5 mm compr., campanulado, lanceolado, ápice acuminado; corola alvo-roxeada a roxa; estandarte $20-22 \mathrm{~mm}$ compr., levemente oblíquo, ápice retuso, 2 apêndices oblíquos basais, levemente unciformes, base unguiculada, porção superior da unguícula com calosidades; alas $20 \mathrm{~mm}$ compr., roxas, base auriculada e unguiculada; pétalas da quilha $11 \mathrm{~mm}$ compr., carena roxas, espiraladas, apêndice longitudinal bilateral; androceu com tubo estaminal auriculado; estame vexilar basalmente giboso; ovário glabrescente na margem; estilete rígido na espiral, inicialmente sulcado e compresso e depois afinando e tornando-se angular; estigma torcido, pubescente. Legumes $9 \mathrm{~cm}$ compr., lineares, amarelos; sementes não observadas.

Material examinado: BRASIL. MAto Grosso do Sul: Corumbá, Serra Santa Cruz, Planalto Residual do Uruucm, 17-I-2003, fl., fr., Silva \& Velásquez 150 (UEC); 30-IX-2003, Silva \& Silva 292 (UEC); 31-X-2003, fl., Silva \& Silva 525 (UEC).

No Brasil, ocorre nos estados de AP, PA, AM, TO, AC, RO, GO, DF, MT, MS, MG, SP, RJ e PR (Moreira 1997, Perez 2010). No PRU, ocupa a floresta estacional decidual e campo cerrado, entre 170 e $900 \mathrm{~m}$ de altitude.

31. Zornia J. F. Gmel., Sist. Nat. 2 (2): 1076. 1791.

Chave para as espécies de Zornia

1. Ramos velutinos; folíolos com indumento viloso 31.5. Z. villosa

1. Ramos glabros, pubescentes a vilosos; folíolos sem este tipo de indumento

2. Estípulas 3-6 nervuras, estrigosas a seríceas

3. Cálice com 8 nervuras, estrigoso

31.1. Z. cryptantha

3. Cálice com 7 nervuras, pubescente 31.2. Z. latifolia

2. Estípulas com 7-8 nervuras, glabras

4. Lomentos inclusos nas bractéolas

31.3.Z. pardina

4. Lomentos exsertos às bractéolas 31.4. Z. reticulata 
31.1. Zornia cryptantha Arechav., Mus. Nac. Montevideo 3: 358. 1901.

Subarbustos, ca. $70 \mathrm{~cm}$ alt. Ramos eretos, vilosos. Folhas 2-folioladas; pecíolo 10-20 mm compr.; estípulas 11-17 mm compr., peltadas, sem pontuações, 6 nervuras, estrigosas; folíolos 20-40 × 6-12 mm, pontuados, oval-lanceolados a lanceolados, ápice agudo, estrigosos em ambas as faces; pecíolo 10-22 mm compr. Inflorescências espiciformes, congestas; pedúnculo 3-5 cm compr.; bractéolas oval-lanceoladas, peltadas, pontuadas, 6-7 nervuras longitudinais, pubescentes; cálice $4 \mathrm{~mm}$ compr., verde, 8 nervuras, estrigoso na base, ápice ciliado, margem ciliada; corola amarela; estandarte $12 \mathrm{~mm}$ compr., orbicular, ápice emarginado, externamente subviloso próximo ao ápice; alas 7-8 $\mathrm{mm}$ compr., oblongas, esculturadas; pétalas da quilha 8-9 $\mathrm{mm}$ compr., falcado-oblongas, unidas às alas, coalescentes no dorso, esculturadas; estames 10, monadelfos; ovário curtamente estipitado, lateralmente estrigoso; estilete punctiforme; estigma diminuto. Lomentos acuminados, 5-articulados; artículos 2-3 mm compr., levemente exsertos, reticulados, com acúleos puberulentos, margem ciliada; sementes reniformes, testa lisa, marrom.

Material examinado: BRASIL. Mato Grosso do Sul: Corumbá, Serra Santa Cruz, Planalto Residual do Urucum, 7-II-2003, fl., fr., Silva \& Silva 238A (UEC).

No Brasil, ocorre nos estados de DF, GO, MT, MS, MG, PR, RS, SP e SC (Silva et al. 2007, Perez 2009). No PRU, foi coletada em floresta estacional semidecidual, a $600 \mathrm{~m}$ de altitude.

\subsection{Zornia latifolia Sm., Cycl. 39: 4. 1819.}

Subarbustos semiprostrados, $15-25 \mathrm{~cm}$ alt. Ramos delgados, ramificados, pontuados, vilosos. Folhas 2-folioladas; pecíolo 10-25 mm compr.; estípulas 5-9 mm compr., peltadas, lanceoladas, 3-5 nervuras longitudinais, pontuadas, seríceas a glabras; pecíolo 9-25 mm compr.; folíolos superiores 1,8-4,5 × 0,8-1,7 cm, lanceolados, base oblíqua, ápice agudo, os inferiores 1,7-4,2 × 0,8-1,6 cm, largo-lanceolados, pontuados e seríceos em ambas as faces, base arredondada, ápice agudo, mucronado. Inflorescências espiciformes, congestas, axilares a terminais; pedúnculo 4-6 cm compr.; bractéolas peltadas, pontuadas, linear-lanceoladas a ovallanceoladas, 5 nervuras longitudinais, seríceas; cálice $3 \mathrm{~mm}$ compr., verde, 7 nervuras, pubescente, lacínias desiguais; estandarte 6-7 $\mathrm{mm}$ compr., orbicular, ápice emarginado; alas 4-7 mm compr., obovais, esculturadas, lunado-lameladas, glabras; pétalas da quilha 4-9 mm compr., encurvadas, glabras; estames 10, monadelfos; ovário séssil, pubescente; estilete curvo; estigma diminuto. Lomentos marrons, 4-8-articulados, exsertos às bractéolas; artículos 2-3 mm compr., suborbiculares, aculeados, pubescentes; sementes reniformes, testa lisa, marrom.

Material examinado: BRASIL. Mato Grosso do Sul: Corumbá, Serra Santa Cruz, Planalto Residual do Urucum, Mineração Corumbaense, 15-II-2005, fl., Pott et al. 12535 (HMS). Ladário, Serra do Rabichão, Planalto Residual do Urucum, fazenda Uruba, 17-X-2003, fr., Silva \& Silva 364 (COR).

No Brasil é citada para os estados de RR, AP, PA, AM, AC, RO, MA, PI, SE, CE, PE, BA, RN, PB, GO, MT, MS, MG, ES, SP, RJ, PR e RS, (Perez 2009). No PRU, foi encontrada nas formações de campo cerrado e bancada laterítica, entre 115 e $990 \mathrm{~m}$ de altitude.

\subsection{Zornia pardina Mohl. var. pardina, Webbia} 16 (1): 84-86. 1961.

Subarbustos xilopodíferos, $35 \mathrm{~cm}$ alt. Ramos prostrados, pontuados, pubescentes a glabros. Folhas 2-folioladas; pecíolo 8-13 mm compr.; estípulas 6-12 mm compr., peltadas, 8 nervuras, glabras; folíolos 1,5-3 × 1,0-1,5 cm, suborbiculares a ovais, pontuados e glabros em ambas as faces, base obtusa, ápice obtuso a agudo; pecíolo 8-13 $\mathrm{mm}$ compr. Inflorescências espiciformes, congestas, axilares a terminais; pedúnculo 4-7 cm compr.; bractéolas lanceoladas a oval-lanceoladas, peltadas, pontuadas, agudas, 6-7 nervuras longitudinais, glabras no dorso; cálice 3,5 mm compr., verde, 7-10 nervuras, estrigoso; corola amarela; estandarte $5 \mathrm{~mm}$ compr., orbicular, reticulado, glabro; alas 2-3 mm compr., obovais; pétalas da quilha 4-5 mm compr., oblongas; estames 10, monadelfos; ovário lateralmente viloso. Lomentos castanhos, 2-6-articulados; artículos 1,5-3 mm compr., inclusos nas bractéolas, com ou sem acúleos, pubescentes; sementes reniformes, testa lisa, marrom.

Material examinado: BRASIL. Mato Grosso do SUL: Corumbá, Serra Santa Cruz, Planalto Residual do Urucum, Mineração Corumbaense, 15-II-2005, fl., fr., Pott et al. 12535 (HMS).

* O nome atual de Vigna linearis (Kunth) Maréchal, Marscherpa \& Stainier é Helicotropis linearis (Kunth) A. Delgado, proposto em Amer. J. Bot. 98(10): 1709. 2011. 
No Brasil é citada para os estados de RR, AP, PA, AM, AC, RO, MA, PI, CE, PE, BA, RN, PB, GO, MT, MS, MG, ES, SP, RJ, PR, SC e RS (Mohlenbrock 1961, Silva et al. 2007, Perez 2009). No PRU, foi encontrada em fitofisionomia de campo sujo de cerrado, a $1.000 \mathrm{~m}$ de altitude.

\subsection{Zornia reticulata Sw., Cycl. 39: 2. 1818.}

Subarbustos, 10-30 cm alt. Ramos cilíndricos, eretos, prostrados a semiprostrados, pontuados, glabrescentes. Folhas 2-folioladas; pecíolo 8-20 mm compr.; estípulas 9-16 mm compr., peltadas, acuminadas, 7-8 nervuras, pontuadas, glabras; pecíolo 8-30 mm compr.; folíolos 2-4 × 0,3-1 cm, lanceolados a oval-lanceolados, pontuados e glabros em ambas as faces, base subaguda, ápice agudo. Inflorescências espiciformes, congestas, axilares a terminais; pedúnculo 3-5 cm compr.; bractéolas largo-ovais, agudas a acuminadas, 5-6 nervuras longitudinais, peltadas, pontuadas, seríceas a glabras; cálice $4 \mathrm{~mm}$ compr., verde, membranáceo, 7-10 nervuras, estrigoso; corola com estandarte 5-10 mm compr., amarelo com guias vináceas, orbicular, pubescente próximo ao ápice; alas 4-8 $\mathrm{mm}$ compr., amarelas, obovais, esculturadas; pétalas da quilha 4-9 $\mathrm{mm}$ compr., alvo-esverdeadas, falcadas, esculturadas; ovário lateralmente tomentoso; estilete curvo; estigma diminuto. Lomentos castanhos, 4-7-articulados; artículos 1,5-2,5 mm compr., exsertos às bractéolas, geralmente reticulados, aculeados, seríceos; sementes reniformes, testa lisa, marrom.

Material examinado: BRASIL. Mato Grosso do Sul: Corumbá, Serra Santa Cruz, Planalto Residual do Urucum, 7-II-2003, fl., Silva \& Silva 238 (UEC); 10-II-2002, fl., Silva \& Silva 254 (UEC); 15-XII-2004, fl., fr., Silva \& Silva 1345 (UEC). Ladário, Serra do Rabichão, Planalto Residual do Urucum, 17-X-2003, fl., fr., Silva \& Silva 364 (UEC); 11-XII-2003, fl., fr., Silva \& Silva 643 (UEC).

No Brasil, ocorre nos estados de RR, PA, PE, MA, BA, GO, DF, MT, MS, MG, SP, RJ, PR, SC e RS (Mohlenbrock 1961, Silva et al. 2007, Perez 2009). No PRU, foi coletada na vegetação de bancada laterítica e campo cerrado, entre 223 e $1.005 \mathrm{~m}$ de altitude.

31.5. Zornia villosa (Malme) Herter, Rev. Sudamer. Bot. 7: 210. 1943

Subarbustos, $40 \mathrm{~cm}$ alt. Ramos cilíndricos, suberetos, velutinos, pontuados. Folhas alternas, 2-folioladas; pecíolo 5-13 mm compr.; estípulas 7-18 mm compr., peltadas, falcadas, oval-lanceoladas, agudas, pontuadas; pecíolo 5-12 mm compr.; folíolos 1,2-3,5 × 0,5-1,1 cm compr., lanceolados, pontuações não visíveis, viloso em ambas as faces, base obtusa, ápice obtuso, mucronado. Inflorescências espiciformes, terminais; pedúnculo 3-4 cm compr.; bractéolas peltadas, oval-lanceoladas, 5 nervuras longitudinais, vilosas, pontuadas; cálice 3-5 mm compr., com lobos desiguais, 5-7 nervuras, pubescente; corola amarela; estandarte 5-8 mm compr., oval, glabro; alas 5-7 m compr., oblongas, glabras; pétalas da quilha 6-7 mm compr., coalescentes, encurvadas, glabras; estames 10, monadelfos; ovário séssil, piloso; estilete curvo; estigma punctiforme. Lomentos marrons, 4-7-articulados; artículos $2 \mathrm{~mm}$ compr., exsertos a inclusos nas bractéolas, aculeados, glabros; sementes reniformes, testa lisa, marrom a amarelada.

Material examinado: BRASIL. Mato Grosso do SuL: Corumbá, Serra Santa Cruz, Planalto Residual do Urucum, Mineração Corumbaense, 21-II-2005, fl., fr., Pott \& Pott 12613 (HMS).

No Brasil, ocorre nos estados de BA, DF, GO, MT, MS, MG, SP, RJ, PR e RS (Silva et al. 2007, Perez 2009). No PRU, foi coletada em campo cerrado, a $994 \mathrm{~m}$ de altitude.

\section{Agradecimentos}

As autoras agradecem à Coordenação de Aperfeiçoamento de Pessoal de Nível Superior (CAPES) pela bolsa de Doutorado. Aos curadores dos herbários COR, CGMS, CPAP, HMS, MBM, RB, SPF, SP, UEC, UFMT, UPCB, USZ, pelo acesso à consulta do material e/ou empréstimo de exsicatas. À Empresa Vale S.A. e ao Grupo Rio Tinto Brasil pelo apoio logístico. Ao José Soares Velásquez e ao Sargento da Marinha do Brasil Márcio Venino da Silva pelo auxílio no trabalho de campo. À Margarete Brandão pelas ilustrações.

\section{Literatura citada}

Alves, F.M. 2008. Leguminosae: Caesalpinioideae e Papilionoideae de um remanescente de chaco em Porto Murtinho, MS, Brasil. Dissertação de Mestrado, Universidade Federal de Mato Grosso do Sul, Campo Grande.

Azevedo,A.M.G. 1981. Ogênero Desmodium Desv. no Brasil: considerações taxonômicas. Dissertação de Mestrado, Universidade Estadual de Campinas, Campinas. 
Barroso, G.M., Morim, M.P., Peixoto, A.L. \& Ichaso, C.L.F. 1999. Frutos e sementes: morfologia aplicada à sistemática de dicotiledôneas. Imprensa Universitária, Viçosa.

Bortoluzzi, R.L.C., Carvalho-Okano, R.M., Garcia, F.C.P. \& Tozzi, A.M.G.A. 2004. Leguminosae, Papilionoideae no Parque Estadual do Rio Doce, Minas Gerais, Brasil: árvores e arbustos escandentes. Acta Botanica Brasílica 18: 49-71.

Brasil. 1982. Projeto RadamBrasil - Folha SE-21. Corumbá: geologia, geomorfologia, pedologia, vegetação e uso potencial da terra. Serie Levantamento de Recursos Naturais 27. Ministério das Minas e Energia, Rio de Janeiro.

Burkart, A. 1971. El gênero Galactia (Legum.-Phaseoleae) em sudamérica com especial referencia a la Argentina y paises vecinos. Darwiniana 16: 663-796.

Cardoso, D.B.O.S. 2010. Sweetia. In: R.C.Forzza et al. (Coords.). Lista de Espécies da Flora do Brasil. Jardim Botânico do Rio de Janeiro. http://floradobrasil.jbrj.gov. br/2010/FB029898 (acesso em 03.12.2010).

Carvalho-Okano, R.M. \& Leitão Filho, H.F. 1985. Revisão taxonômica do gênero Calopogonium Desv. (Leguminosae - Lotoideae) no Brasil. Revista Brasileira de Botânica 8: 31-45.

Costa, N.M.S. 2006. Revisão do gênero Stylosanthes Sw. Tese de Doutorado, Universidade Técnica de Lisboa, Instituto Superior de Agronomia, Lisboa.

Costa, L.C., Sartori, A.L.B. \& Pott, A. 2008. Estudo taxonômico de Stylosanthes (LeguminosaePapilionoideae-Dalbergieae) em Mato Grosso do Sul, Brasil. Rodriguésia 59: 547-572.

Costa, L.C. \& Valls, J.F.M. 2010. Stylosanthes. In: R.C. Forzza et al. (coords.). Lista de Espécies da Flora do Brasil. Jardim Botânico do Rio de Janeiro. http:// floradobrasil.jbrj.gov.br/2010/FB029860 (acesso em 03.12.2010).

Ferreira, M.B. \& Costa, N.M.S. 1979. O gênero Stylosanthes Sw. no Brasil. EPAMIG, Belo Horizonte.

Fernandes, A. 1996. O táxon Aeschynomene no Brasil. EUFC, Fortaleza.

Filardi, F.L.R. 2010. Machaerium. In: R.C. Forzza et al. (coords.). Lista de Espécies da Flora do Brasil. Jardim Botânico do Rio de Janeiro. http://floradobrasil.jbrj.gov. br/2010/FB029758 (acesso em 03.12.2010).

Filardi, F.L.R., Garcia, F.C.P., Dutra, V.F. \& São-Thiago, P.S. 2007. Papilionoideae (Leguminosae) do Parque Nacional da Serra da Canastra, Minas Gerais, Brasil. Hoehnea 34: 383-408.

Flores, A.S. 2004. Taxonomia, números cromossômicos e química de espécies de Crotalaria L. (LeguminosaePapilionoideae) no Brasil. Tese de Doutorado, Universidade Estadual de Campinas, Campinas.
Flores, A.S. 2010. Crotalaria. In: R.C. Forzza et al. (coords.). Lista de Espécies da Flora do Brasil. Jardim Botânico do Rio de Janeiro. http://floradobrasil.jbrj.gov. br/2010/FB082985 (acesso em 03.12.2010).

Fortunato, R.H. 2010a. Eriosema. In: R.C. Forzza et al. (coords.). Lista de Espécies da Flora do Brasil. Jardim Botânico do Rio de Janeiro. http://floradobrasil.jbrj.gov. br/2010/FB029652 (acesso em 03.12.2010).

Fortunato, R.H. 2010b. Galactia. In: R.C. Forzza et al. (coords.). Lista de Espécies da Flora do Brasil. Jardim Botânico do Rio de Janeiro. http://floradobrasil.jbrj.gov. br/2010/FB029682 (acesso em 03.12.2010).

Fortunato, R.H. 2010c. Rhynchosia. In: R.C. Forzza et al. (coords.). Lista de Espécies da Flora do Brasil. Jardim Botânico do Rio de Janeiro. http://floradobrasil.jbrj.gov. br/2010/FB019013 (acesso em 03.12.2010).

Grear, J.W. 1970. A revision of the American species of Eriosema. Memoirs of the New York Botanical Garden 20: 1-98.

Guedes-Bruni, R.R., Morim, M.P., Lima, H.C. \& Sylvestre, L.S. 2002. Inventário florístico. In: L.S. Sylvestre \& M.M.T. Rosa (eds.). Manual metodológico para estudos na Mata Atlântica. Universidade Federal do Rio de Janeiro, Seropédica, pp. 24-49.

Gunn, C.R. 1981. Seeds of leguminosae. In: R.M. Polhill \& P.H. Raven (eds.). Advances in Legume Systematics. Crow, Kew, pp. 913-925.

Hickey, M. \& King, C. 2004. The Cambridge Illustred Glossary of Botanical Terms. University Press, Cambridge.

Iesquierdo, S.W.G. 1997. Análise Integrada da Sub-Bacia da Lagoa Negra - MS: Um ensaio de cartografia temática com aplicação de SIG. Dissertação de Mestrado, Universidade de São Paulo, São Paulo.

Iganci, J.R.V. \& Miotto, S.T.S. 2010. Sesbania. In: R.C. Forzza et al. (coords.). Lista de Espécies da Flora do Brasil. Jardim Botânico do Rio de Janeiro. http:// floradobrasil.jbrj.gov.br/2010/FB019125 (acesso em 03.12.2010).

Ireland, H.E. 2001. The taxonomy and systematic of Ateleia and Cyathostegia (Leguminosae-Swartzieae). $\mathrm{PhD}$ thesis, The University of Reading, Reading,.

Krukoff, B.A. \& Barneby, R.C. 1974. Conspectus of species of the genus Erythrina. Lloydia 37: 332-459.

Lavin, M. 1988. Systematics of Coursetia (LeguminosaePapilionoideae). Systematic Botany Monographs 21: 1-167.

Lewis, G.P. 1987. Legumes of Bahia. Royal Botanic Gardens, Kew.

Lewis, G.P., Schrire, B., Mackinder, B. \& Lock, M. 2005. Legumes of the World. Royal Botanical Gardens, Kew.

Lima, H.C. 2010a. Alysicarpus. In: R.C. Forzza et al. (coords.). Lista de Espécies da Flora do Brasil. Jardim Botânico do Rio de Janeiro. http://floradobrasil.jbrj.gov. br/2010/FB120430 (acesso em 03.12.2010). 
Lima, H.C. 2010b. Amburana. In: R.C. Forzza et al. (coords.). Lista de Espécies da Flora do Brasil. Jardim Botânico do Rio de Janeiro. http://floradobrasil.jbrj.gov. br/2010/FB022781 (acesso em 03.12.2010).

Lima, H.C. 2010c. Calopogonium. In: R.C. Forzza et al. (coords.). Lista de Espécies da Flora do Brasil. Jardim Botânico do Rio de Janeiro. http://floradobrasil.jbrj.gov. br/2010/FB029628 (acesso em 03.12.2010).

Lima, H.C. 2010d. Dipteryx. In: R.C. Forzza et al. (coords.). Lista de Espécies da Flora do Brasil. Jardim Botânico do Rio de Janeiro. http://floradobrasil.jbrj.gov. br/2010/FB 022853). (acesso em 03.12.2010).

Lima, H.C. 2010e. Erythrina. In: R.C. Forzza et al. (coords.). Lista de Espécies da Flora do Brasil. Jardim Botânico do Rio de Janeiro. http://floradobrasil.jbrj.gov. br/2010/FB029675 (acesso em 03.12.2010).

Lima, H.C. 2010f. Platypodium. In: R.C. Forzza et al. (coords.). Lista de Espécies da Flora do Brasil. Jardim Botânico do Rio de Janeiro. http://floradobrasil.jbrj.gov. br/2010/FB023124 (acesso em 03.12.2010).

Lima, L.C.P. \& Oliveira, M.L.A.A. 2010a. Aeschynomene. In: R.C. Forzza et al. (coords.). Lista de Espécies da Flora do Brasil. Jardim Botânico do Rio de Janeiro. http://floradobrasil.jbrj.gov.br/2010/FB022778 (acesso em 03.12.2010).

Lima, L.C.P. \& Oliveira, M.L.A.A. 2010b. Desmodium. In: R.C. Forzza et al. (coords.). Lista de Espécies da Flora do Brasil. Jardim Botânico do Rio de Janeiro. http://floradobrasil.jbrj.gov.br/2010/FB022935 (acesso em 03.12.2010).

Lima, L.C.P., Sartori, A.L.B. \& Pott, V.J. 2006. Aeschynomene L. (Leguminosae, Papilionoideae, Aeschynomene) no Estado de Mato Grosso do Sul, Brasil. Hoehnea 33: 419-453.

Mendonça, R.C., Felfilli, J.M., Walter, B.M.T., Silva Júnior, M.C., Rezende, A.V., Filgueiras, T.S. \& Nogueira, P.E. 1998. Flora vascular do Cerrado. In: M. Sano \& S.P. Almeida (eds.). Cerrado: ambiente e flora. EMBRAPA - CPAC, Planaltina, pp. 287-556.

Miotto, S.T.S. \& Iganci, J.R.V. 2010. Indigofera. In: R.C. Forzza et al. (coords.). Lista de Espécies da Flora do Brasil. Jardim Botânico do Rio de Janeiro. http:// floradobrasil.jbrj.gov.br/2010/FB029538 (acesso em 03.12.2010).

Mohlenbrock, R.H. 1957. A revision of the genus Stylosanthes. Annals of the Missouri Botanical Garden 44: 229-308.

Mohlenbrock, R.H. 1961. Amonograph of the Leguminosae genus Zornia. Webbia 16: 1-141.

Mohlenbrock, R.H. 1963. A revision of the leguminous genus Sweetia. Webbia 17: 223-263.

Moreira, J.L.A. 1997. Estudo taxonômico da subtribo Phaseolinae Benth. (Leguminosae, Papilionoideae) no Sudeste e Centro-Oeste do Brasil. Tese de Doutorado, Universidade Estadual de Campinas, Campinas.
Okida, R. \& Anjos, C.E. 2000. Geomorfologia. In: J.S.V. Silva (ed.). Zoneamento ambiental da Borda Oeste do Pantanal: Maciço do Urucum e Adjacências. Embrapa Comunicação e Transferência de Tecnologia. EMBRAPA-CPAP, Brasília, pp. 47-54.

Perez, A.P.F. 2009. O gênero Zornia J.F. Gmel. (Leguminosae, Papilionoideae, Dalbergieae): Revisão taxonômica das espécies ocorrentes no Brasil e filogenia. Tese de Doutorado, Universidade Estadual de Campinas, Campinas.

Perez, A.P.F. 2010. Vigna. In: R.C. Forzza et al. (coords.). Lista de Espécies da Flora do Brasil. Jardim Botânico do Rio de Janeiro. http://floradobrasil.jbrj.gov.br/2010/ FB083860 (acesso em 03.12.2010).

Pennington, R.T. 2003. Monograph of Andira (Leguminosae-Papilionoideae). Systematic Botany Monographs 64: 1-143.

Polhill, R.M. 1981. Advances in legume systematics. Royal Botanical Gardens, Kew.

Polido, C.A. \& Sartori,A.L.B. 2007. O gênero Machaerium (Leguminosae-Papilionoideae-Dalbergieae) no Pantanal brasileiro. Rodriguésia 58: 313-329.

Pott, A., Silva, J.S.V., Salis, S.M., Pott, V.J. \& Silva, M.P. 2000. Vegetação e uso da terra. In: J.S.V. Silva (ed.). Zoneamento ambiental da Borda Oeste do Pantanal: Maciço do Urucum e Adjacências. Embrapa Comunicação e Transferência de Tecnologia. EMBRAPA-CPAP, Brasília, pp. 111-131.

Queiroz, L.P. 2010. Camptosema. In: R.C. Forzza et al. (coords.). Lista de Espécies da Flora do Brasil. Jardim Botânico do Rio de Janeiro. http://floradobrasil.jbrj.gov. br/2010/FB 029500 (acesso em 03.12.2010).

Rando, J.E. \& Souza, V.C. 2010. Clitoria. In: R.C. Forzza et al. (coords.). Lista de Espécies da Flora do Brasil. Jardim Botânico do Rio de Janeiro. http://floradobrasil. jbrj.gov.br/2010/FB029538 (acesso em 03.12.2010).

Ratter, J.A., Askew, G.P., Montgomery, R.F. \& Gifford, D.R. 1978. Observations on the vegetation of northeastern Mato Grosso. II. Forests and soils of the Rio Suiá-Missu area. Proceedings of the Royal Society of London (ser. B) 203:191-208.

Rodas, R.D. 1991. Estudo taxonômico do gênero Indigofera L. (Leguminosae) no Brasil e no Paraguai. Dissertação de Mestrado, Universidade Federal do Rio de Janeiro, Rio de Janeiro.

Rodrigues, R.S. 2009. Novos sinônimos e lectotificação em Sweetia Spreng. (Leguminosae, Papilionoideae). Revista Brasileira de Biociências 7: 134-137.

Rodrigues, R.S. \& Tozzi, A.M.G.A. 2009. Revisão taxonômica de Acosmium Schott (Leguminosae, Papilionoideae, Sophoreae). Acta Botanica Brasilica 23: 164-174. 
Rudd, V.E. 1955. The American species of Aeschynomene. Contributions of the United States National Herbarium 32: 1-172.

Rudd, V.E. 1958. A revision of the genus of Chaetocalyx. Contributions from the United States National Herbarium 32: 207-245.

Sauer, J. 1964. Revision of Canavalia. Brittonia 16: 106-181.

Silva, E.D. 2005. A subfamília Papilionoideae (Leguminosae Adans.) na Serra do Cabral, Minas Gerais. Dissertação de Mestrado, Universidade Estadual de Campinas, Campinas.

Silva, E.D. 2010. Leguminosae na Floresta Ombrófila Densa do Parque Estadual da Serra do Mar, Núcleos Picinguaba e Santa Virgínia, São Paulo, Brasil: taxonomia e similaridade entre as diferentes cotas altitudinais. Tese de Doutorado, Universidade Estadual de Campinas, Campinas.

Silva, R.R. 2006. Leguminosae no Planalto Residual do Urucum, oeste do Pantanal do Mato Grosso do Sul, Brasil: inventário, taxonomia e similaridade florística. Tese de Doutorado, Universidade Estadual de Campinas, Campinas.
Silva, R.R. \& Tozzi, A.M.G.A. 2008. A new species of Lonchocarpus (Leguminosae, Papilionoideae) from Mato Grosso do Sul, Brazil. Brittonia 60: 34-37.

Silva, R.R., Fortuna-Perez, A.P. \& Tozzi, A.M.G.A. 2007. Novas ocorrências de Leguminosae para o Mato Grosso do Sul, Brasil. Rodriguésia 58: 249-254.

Soriano, B.M.A. 2000. Climatologia. In: J.S.V. Silva (ed.). Zoneamento ambiental da Borda Oeste do Pantanal: Maciço do Urucum e Adjacências. Embrapa Comunicação e Transferência de Tecnologia. EMBRAPA-CPAP, Brasília, pp. 69-82.

Souza, V.C. 2010. Centrosema. In: R.C. Forzza et al. (coords). Lista de Espécies da Flora do Brasil. Jardim Botânico do Rio de Janeiro. http://floradobrasil.jbrj.gov. br/2010/FB029516 (acesso em 03.12.2010).

Stirton, C.H. 1981. Petal Sculpturing in Papilionoideae Legumes. In: R.M. Polhill \& P.H. Raven (eds.). Advances in Legume Systematics. Crow, Kew, pp. 771-788.

Vanni, R. 2001. Él género Desmodium (Leguminosae, Desmodieae) en Argentina. Darwiniana 39: 255-285.

Webberling, F. 1992. Morphology of flowers and inflorescences. University Press, Cambridge. 